NBER WORKING PAPER SERIES

ECONOMIC WELL-BEING AND ANTI-SEMITIC, XENOPHOBIC, AND RACIST
ATTITUDES IN GERMANY

Naci H. Mocan

Christian Raschke

Working Paper 20059

http://www.nber.org/papers/w20059

\author{
NATIONAL BUREAU OF ECONOMIC RESEARCH \\ 1050 Massachusetts Avenue \\ Cambridge, MA 02138 \\ April 2014
}

We thank Luiza Pogorelova and Bahadir Dursun for research assistance. Anna Piil Damm, Marianne Simonsen, Alex Koch, Leyla Mocan, Carmine Guerriero, James Garand, and seminar participants at Aarhus University, Galatasaray University and LSU provided helpful comments. The views expressed herein are those of the authors and do not necessarily reflect the views of the National Bureau of Economic Research.

NBER working papers are circulated for discussion and comment purposes. They have not been peerreviewed or been subject to the review by the NBER Board of Directors that accompanies official NBER publications.

(C) 2014 by Naci H. Mocan and Christian Raschke. All rights reserved. Short sections of text, not to exceed two paragraphs, may be quoted without explicit permission provided that full credit, including (C) notice, is given to the source. 
Economic Well-being and Anti-Semitic, Xenophobic, and Racist Attitudes in Germany Naci H. Mocan and Christian Raschke

NBER Working Paper No. 20059

April 2014

JEL No. I30,J15,Z1

\begin{abstract}
$\underline{\text { ABSTRACT }}$
The fear and hatred of others who are different has economic consequences because such feelings are likely to translate into discrimination in labor, credit, housing, and other markets. The implications range from earnings inequality to intergenerational mobility. Using German data from various years between 1996 and 2010, we analyze the determinants of racist and xenophobic feelings towards foreigners in general, and against specific groups such as Italians and Turks. We also analyze racist and anti-Semitic feelings towards German citizens who differ in ethnicity (Aussiedler from Eastern Europe) or in religion (German Jews). Individuals' perceived (or actual) economic well-being is negatively related to the strength of these feelings. Education, and having contact with foreigners mitigate racist, anti-Semitic and xenophobic feelings. People who live in states which had provided above-median support of the Nazi party in the 1928 elections have stronger anti-Semitic feelings today. The results are not gender-driven. They are not an artifact of economic conditions triggering feelings about job priority for German males, and they are not fully driven by fears about foreigners taking away jobs. The results of the paper are consistent with the model of Glaeser (2005) on hate, and with that of Akerlof and Kranton (2000, 2005) on identity in the utility function.
\end{abstract}

Naci H. Mocan

Department of Economics

Louisiana State University

3039 BEC

Baton Rouge, LA 70803-6306

and NBER

mocan@1su.edu

Christian Raschke

Sam Houston State University

Department of Economics and International Business

237L Smith-Hutson Building

1821 Ave. I

Huntsville, TX 77340

Raschke@shsu.edu 


\section{Economic Well-being and Anti-Semitic, Xenophobic, and Racist Attitudes in Germany}

\section{$\underline{\text { I. Introduction }}$}

Different societies around the world have different values. For example, attitudes towards the importance of the family, opinions on the extent to which children should respect their parents, and the significance of family ties vary substantially across countries. Such cultural differences have an influence on economic behavior. Alesina and Giuliano (2010) show that labor force participation of women, the propensity to live with parents, geographic mobility, and family size of immigrants in the Unites States are influenced by the strength of family ties in their country of origin, and that this influence persists even among the second generation of immigrants. Similarly, Fernandez and Fogli (2009) show that work and fertility decisions of second-generation American women are influenced by their cultural attitudes, approximated by the past female labor force participation rate and the fertility rate of the woman's country of ancestry. Luttmer and Singhal (2011) report a strong positive relationship between immigrants' own preferences for income redistribution and the average preference for redistribution of the citizens of their country of birth.

A dimension of culture, which is widely employed in current research, is the extent to which one group of people trust or distrust others who are "different." Guiso et al. (2009) report the existence of substantial differences in the level of trust among the residents of various European countries. They show that cultural biases that determine the lack of bilateral trust between countries have a significant impact on the level of trade between countries, on portfolio 
investment and on foreign direct investment. Bottazzi et al. (2011) find that the extent of trust among different nations has an impact on investment decisions. Helliwell at al. (2014) find that social trust and social norms in the source country have a substantial impact on immigrants' level of trust in the destination country.

Attitudes of the members of a given society towards people who are different from them may be shaped by a variety of factors, including economic and military conflicts, interactions with other societies in the form of trade and travel, similarities in religion and language, as well as historical accidents (e.g. Alesina, Giuliano and Nunn, 2013). Attitudes, such as trust, which are part of the fabric of culture, are assumed to be rather stable and not to change quickly. Guiso et al. (2006) and Luttmer and Singhal (2011) define culture as "those customary beliefs and values that ethnic, religious, and social groups transmit fairly unchanged from generation to generation." Yet, beliefs and attitudes, even those that are deeply ingrained in human psyche, may be more malleable than presumed. For example, Mocan (2013) shows that the extent of vengeful feelings of individuals is impacted by economic and social circumstances of the individuals and the country in which the live. Thus, it is possible that even very strong beliefs, such as those that are racist or borderline racist, may be influenced by economic circumstances.

Research that focuses on trust/mistrust as a dimension of culture measures trust placed in others with questions such as "I would like to ask you a question about how much trust you have in people from [country X]." In this paper we measure sentiments that are much stronger than trust/mistrust. Specifically, we analyze the determinants of Germans' xenophobic, anti-Semitic and racist feelings, measured by their reactions towards "others" who live in Germany. In this case "others" represent either Jewish people, ethnic Germans from Eastern Europe, or foreigners such as Italians and Turks who reside in Germany. We analyze responses to such statements as 
“Jews (alternatively, Italians, Turks, or ethnic Germans from Eastern Europe) living in

Germany should not have the same rights as Germans in every respect," "Foreigners living in Germany should choose to marry people of their own nationality," "Foreigners living in Germany should be prohibited from taking part in any kind of political activity." We use the answers to these and similar questions to investigate the extent to which these anti-Semitic, xenophobic or racist attitudes are impacted by personal characteristics and economic well-being of the respondents. The details of the questions are given in the data section.

Some related research exists that investigates the extent to which economic conditions alter individuals' support for extreme political views. For example, parents' unemployment status is shown to have an impact on their offspring's propensity to support extreme right-wing parties (Siedler 2011). On the other hand, evidence is mixed on the impact of aggregate economic conditions on hate crime. Hovland and Sears (1940) reported a negative association between lynchings in 14 southern states of the United States and several indicators of economic conditions, which is confirmed by Hepworth and West (1988), although Green, Glaser and Rich (1998) could not find a significant relationship between violence directed to minorities and economic conditions. Kruger and Pischke (1997) could not detect a relationship between unemployment, wages and anti-foreigner crime in Germany, while Falk, Kuhn and Zweimueller (2011) find that the occurrence of right-wing extremist crimes takes place more frequently when unemployment is high in Germany. ${ }^{1}$

\footnotetext{
${ }^{1}$ In a different domain, Mayda (2006) and Facchini and Mayda (2009) investigate the determinants of attitudes towards migration, and Mayda and Rodrik (2005) analyze why some people favor protectionist trade policies while others are pro-trade. Dustmann and Preston (2007) investigate the extent to which attitudes towards immigration are influenced by the labor market, welfare benefit spending, and cultural and racial prejudice in the U.K, and Card, Dustmann and Preston (2012) conduct a similar analysis of preferences over immigration using the 2002 European Social Survey.
} 
As we explain in the data section, the questions we use do not refer to foreigners who reside illegally in Germany. Unlike some other countries, illegal immigration is not a widespread phenomenon in Germany. It is estimated that illegal foreigners constitute less than $0.5 \%$ of the general population (Database on Irregular Immigration 2013). This is primarily because Germany does not share borders with countries that are vastly different economically. Residents of Germany who are not of German origin are typically former Gastarbeiter (guest workers) or the offspring of guest workers, who migrated to Germany legally under official arrangements of the German government and the governments of referral countries. ${ }^{2}$ Alternatively, they are citizens of European Union countries. Thus, both of these groups hold work and residency permits and qualify for almost all rights as native Germans, ranging from political rights to retirement benefits. Therefore, questions analyzed in the paper refer to groups of people who are in Germany legally, but whose cultural heritage is of another country, such as Italians or Turks. Importantly, some of the questions refer to Germans (non-foreigners) who are either religious or ethnic minorities.

\section{Theoretical Underpinnings}

Glaeser (2005) provides a theoretical framework to analyze the political economy of hate. In his model, the supply of hate (in a variety of forms such as anti-Semitism or hatred of Blacks and other minorities) is produced by politicians in the form of hate-creating stories. Hate is supplied against economically disadvantaged minorities by politicians with anti-distribution

\footnotetext{
${ }^{2}$ Being born in Germany does not automatically confer German citizenship. German nationality law is based on the principle of jus sanguinis (right of blood). One or more parent being a citizen determines the citizenship of a child. It is therefore possible to be a $2^{\text {nd }}$ or $3^{\text {rd }}$ generation foreigner living in Germany. This contrasts the jus soli (right of soil) principle, which makes citizenship a right for anyone born in the territory (e.g. in the United States).
} 
platforms and it is spread against rich minorities by pro-redistribution politicians. The willingness of individuals to accept these stories, propagated by politicians, as fact is the demand-side of the hatred. Costs of obtaining information about the hated group and the private benefit of that information will impact the demand. Two predictions emerge from this model. First, education should reduce hate and racism if it is easier for the more educated to obtain information and to distinguish between the correct and incorrect information about the hatepropagated groups. Second, having contact with the hated groups should reduce costs of acquiring information and therefore should result in a reduction in racist feelings. We are able to test both of these predictions.

Akerlof and Kranton (2000) introduce the notion of individual identity as a variable in determining individual behavior. They propose a variation to the neoclassical utility function which includes identity as a component. Identity (or self-image), consistent with social psychology, is defined as belonging to a social category such as race and gender. Everyone in the population is assigned to categories. These identity categories are associated with behavioral prescriptions describing the ideals for each category, ranging from appropriate behavior to physical appearance. An individual's identity depends on the level of consistency between the prescribed level for that category and the person's actions, and identity has a positive impact on utility. For example, consider two identity categories as "Native" and "Foreigner," where the former has higher status than the latter. These categories have prescriptions that include a variety of dimensions, including how to interact with the members of other categories. A prescription for the Native category could be an expectation to not intermingle with foreigners. If somebody who is in the Native category does not intermingle with foreigners, this constitutes a match between his attributes and the prescribed behavior for his category, and it would generate an 
increase in identity and therefore in utility. On the other hand, if the Native interacts with foreigners, this would produce a decline in identity and a decrease in utility. In this model individuals choose actions to maximize utility, and actions determine identities. Akerlof and Kranton (2000) use this model to gain insights into gender discrimination, social exclusion and poverty.

In a different version of the model, Akerlof and Kranton (2005) formulate a utility function which explicitly includes income in addition to the match quality between the person's identity and the prescribed level for that category. In this model, income and identity are substitutes, indicating that a higher level of income allows the individual to deviate from the prescribed level of behavior. That is, a loss in utility due to the decline in identity (because of the deviation from prescribed behavior) can be compensated by higher levels of income. This model provides a theoretical rationale of the relationship between higher economic well-being and lower levels of xenophobia and racism. That is, even if one aspect of the identity of being "native" is the rejection of "foreigners," the decline in identity and loss of utility generated by disregarding this particular prescription can be afforded when the individual's utility is increased due to higher economic well-being. ${ }^{3}$

\section{Summary of the Findings}

We analyze German General Social Survey data between 1996 and 2010. We find that anti-Semitic, xenophobic and racist feelings are influenced by individuals' economic well-being. In addition to personal attributes such as age, gender, education, labor market activity and location of residence, the data set contains questions on the respondents' evaluation of their own

\footnotetext{
${ }^{3}$ Applications of this concept include Humlum, Kleinjans and Nielsen (2012) and Antecol and CobbClark (2008).
} 
economic situation, and how they rate the current economic conditions in Germany. We find that, xenophobic, anti-Semitic and racist feelings are tempered when people believe that their own economic situation is in good shape, and these feelings are magnified when people think that their personal economic situation is bad. The same relationship exists for beliefs about national economic conditions. These results suggest that economic well-being of individuals influence how they perceive others who are "different" from them. More specifically, the negative/intolerant/prejudiced feelings about minorities are mitigated if economic well-being is improved.

Consistent with the prediction of Glaeser (2005) we find that more educated Germans have weaker xenophobic, anti-Semitic or racist feelings. The same is true for those who have contact with foreigners in the workplace, or through family or friends. As noted by Glaeser (2005, p. 56), it is possible that the more educated may be better in hiding racist feelings. Similarly, caution should be exercised in the interpretation of the impact of contact with foreigners because interaction with foreigners may itself be determined by the extent of racist and xenophobic feelings of the person. That is, racists may avoid contacts with foreigners and minorities, while non-racists may choose to have interactions with them. However, we show that the impact of exposure to foreigners is not sensitive to inclusion/exclusion of self-employed people from the analysis, who can clearly pick-and-choose the individuals with whom they interact in the workplace.

Along the same lines of most recent research that has reported persistence of cultural traits, Voigtlaender and Voth (2012a) find that the extent of anti-Semitism 600 years ago, manifested by persecutions and executions of Jews during the plague-era, predicts the support of the Nazi Party in the 1928 elections in Germany. This suggests that anti-Semitic sentiments 
continued to exist in local areas for centuries. We use this idea and include in some of our specifications a measure of local support of the Nazi Party in 1928. We find that people who reside in states that have provided above-median support for the Nazi Party in 1928 are more anti-Semitic today in comparison to those who live elsewhere. ${ }^{4}$ This provides evidence that local cultural traits in terms of anti-Semitism persisted over the last 80 years. This persistence result is consistent with that of Voigtlaender and Voth (2012b) who investigate the extent to which antiSemitic attitudes today are impacted by support for anti-Semitic parties between 1890 and 1933 and how various types of de-Nazification policies implemented under different occupying forces after WWII impacted anti-Semitism in Germany.

We show that the results are not driven by men; that is, very similar results are obtained by analyzing samples of just men or women. Nonetheless, it could be the case that the relationship between economic condition and racist, anti-Semitic and xenophobic feelings is a reflection of men's concern about economic conditions and their beliefs about "men having priority in the job market." If this is true, men's frustration about economic conditions would manifest itself in negative attitudes toward all others competing for jobs, including women. The survey includes questions gauging attitudes on women's involvement in the labor market and on their household responsibilities. These include agreements/disagreements with statements such as "A married woman should give up working if jobs are scarce and husband can provide for family," and "It is better if the husband works and wife stays at home tending to household and children." Analyzing men's responses to such statements, we find that economic conditions have no impact on men's attitudes towards women's attachment to the labor market. This

\footnotetext{
${ }^{4}$ As detailed later, support of the Nazi Party in 1928 is not correlated with the level of development in those areas today; that is, areas that produced more votes for the anti-Semitic Nazi platform in 1928 are not systematically different from other areas today in terms of economic development or level of income.
} 
indicates that perceptions about economic well-being do not trigger across-the-board negative reactions stemming from job insecurity.

In section II we present the data. Section III includes the empirical results, and section IV discusses the robustness of the results. Section V is the conclusion.

\section{Data}

Data used in this study are taken from various waves of the German General Social Survey (ALLBUS) between 1996 and 2010. The German General Social Survey consists of repeated cross sections that are representative of the resident adult population in Germany. The survey is administered every other year. We exclude non-German citizens from our sample. We make use of several questions regarding the attitudes of German citizens towards Jews and ethnic Germans from Eastern Europe, as well as towards foreigners who reside in Germany, such as those with Italian or Turkish heritage. ${ }^{5}$ Each survey year used in the analyses contains about 3,000 observations.

The first variable in Table 1, Foreigners Should Marry Their Own, is based on the response to the statement "Foreigners living in Germany should choose to marry people of their own nationality." Potential answers range from 1: Strongly disagree, to 7: Strongly agree. "Foreigners Should Marry Their Own" takes the value of 1 if the respondent agreed or strongly agreed with this statement (options 5, 6 or 7). Table 1 shows that about $18 \%$ of the sample thinks that foreigners should marry people of their own nationality. The variable titled No Politics for Foreigners takes the value of one if the respondent agrees or strongly agrees with the

\footnotetext{
${ }^{5}$ Depending on the specification, we use up to 13,146 observations.
} 
statement that "Foreigners living in Germany should be prohibited from taking part in any kind of political activity."

To say that somebody should not marry anyone outside their own nationality is an indication of racism. Similarly, despite the fact that German law allows for political participation of foreigners at the local level, trying to prohibit a group of people from participating in any kind of political activity is an attempt to disfranchise that target group economically and socially. While German law does not allow non-German citizens to vote in federal or state elections or to be elected for state or federal office, non-Germans who are citizens of the European Union countries (such as Italy, Greece, Bulgaria, Romania, Poland and Spain) have the right to vote in local elections (city and community elections) and they are eligible to run for office at the local level. Furthermore, any foreigner may be appointed to serve on local committees to represent the interests of a group. They may also participate in community initiatives, labor and trade unions, schools, etc. ${ }^{6}$

The respondents were also given the following statement: "Jewish people living in Germany should have the same rights as other Germans in every respect." Once again, the alternatives ranged from "strongly disagree" to "strongly agree" on a scale from 1 to 7 . If the respondent disagreed with this statement (chose 1, 2 or 3), the variable No Equal Rights for Jews takes the value of one. Note that "the Jewish people" here does not refer to citizens of the state of Israel. Rather, they are Jewish citizens of Germany. To declare that Jewish people should not have the same rights as (non-Jewish) Germans is an indication of anti-Semitism. Table 1 shows

\footnotetext{
${ }^{6}$ (German Federal Ministry of the Interiors web site, accessed on Dec 28, 2013: http://www.bmi.bund.de/ DE/Themen/Gesellschaft-Verfassung/Staatliche-Ordnung/Wahlrecht/Auslaenderwahlrecht/ auslaenderwahlrecht_node.html)
} 
that 22 percent of the respondents indicated agreed that German Jews should not have the same rights.

A similar attitude is observed towards the ethnic Germans from Eastern Europe (Aussiedler). This group of individuals are of German descent who have the right to return to Germany and claim German citizenship. Primarily, the term refers to German citizens (and their descendants) who remained in the former German territories east of the Oder-Neisse line after 1945, as well as refugees or expellees (and their descendants) of German ethnic origin who were admitted to the territories of the German Reich as defined by the boundaries existing in $1937{ }^{7}$ Note that this group includes individuals who may never have lived in Germany. Although some knowledge of the German language is formally required in order to obtain citizenship as an Aussiedler, many Aussiedler do not speak or write German well, and do not use German as their primary language spoken at home (Frick and Wagner 2001). Twenty-eight percent of the sample thinks that these ethnic Germans should not have the same rights as other Germans.

The descriptive statistics of "No Equal Rights for Italians" shows that 26 percent of Germans think that Italians should not have rights equal to Germans. Racism against Turks is stronger; about 45 percent of Germans think that Turks should not have the same rights as Germans.

The next group of variables listed in Table 1 measures feelings that can be described as xenophobia and anti-Semitism. These variables gauge the extent to which respondents would like to avoid having an ethnic German (Aussiedler), a Jewish person, an Italian or a Turk as a neighbor, and whether it would be unpleasant if such a person married into their family. As

\footnotetext{
${ }^{7}$ Sometimes a distinction is made between Aussiedler and Spätaussiedler ("Late Aussiedler"), depending on how soon after World War II the individuals came to present-day Germany. We make no such distinction and refer to all such individuals as "Aussiedler" or "ethnic Germans from Eastern Europe".
} 
shown in Table 1,39\% of Germans think that it would be unpleasant to have a Turkish person as a neighbor, and about $23 \%$ think the same for ethnic Germans from Eastern Europe. Twelve percent think that it would be unpleasant to have a Jewish neighbor and $7 \%$ feel the same for an Italian neighbor. These negative feelings are even stronger when it comes to the possibility of a Turkish person, ethnic German, Jewish person, or an Italian being married into the family of the respondent, but the pecking order remains the same: More than half of Germans indicate that it would be unpleasant to have a Turkish person married into the family, and about $31 \%$ percent have the same feeling about an ethnic German from Eastern Europe (Aussiedler) Jewish person. One-in-four Germans do not like the idea of a Jewish person marrying into the family, and $17 \%$ think it would be unpleasant to have an Italian in the family.

The survey includes questions that ask about perceptions regarding current economic conditions. The respondents were asked "How would you generally rate your own economic situation?" They answered on a five-point scale (Very good, good, neutral, bad, very bad). We combined "good" and "very good" under a dichotomous indicator titled "Good Personal Economic Conditions" and we similarly combined "bad" and "very bad" under "Bad Personal Economic Conditions." The respondents were also asked "How would you generally rate the current economic situation in Germany?" In the same manner we created dichotomous variables “Good National Economic Condition" and "Bad National Economic Condition."

Table 2 shows that about 50 percent of the respondents think that their personal economic conditions are good or very good, and 13 percent think that their personal economic conditions are bad or very bad. The remainder (37\%) thinks that their personal economic condition is neutral. Regarding the economic conditions in Germany, half of the respondents think that it is neutral. While 20 percent think that economic conditions of the country are good or very good, 
29 percent think Germany's economic conditions are bad or very bad. These variables that gauge sentiments of personal or national economic conditions move in tandem, but not perfectly so. For example, of those people who reported that their personal economic conditions were good or very good, only 30 percent indicated that they felt that Germany's economic condition was good or very good.

The survey contains information on personal characteristics of the respondents, such as age, gender, education, and marital status. Survey administrators have merged information regarding the location of residence of the respondent to local area characteristics. This allows us to control for local area attributes in addition to the personal characteristics of the respondents. These characteristics include such variables as the city size and whether the respondent lives in the inner city. The data set also contains information on whether individuals have contact with foreigners at work or through family and friends. The survey question is: "Do you have personal contact with foreigners living in Germany, at your job [... in your immediate family?]" Thirtyeight percent of the people have contact with foreigners at work and 20 percent have contact with foreigners through family.

Religious affiliation is measured by three mutually exclusive categories: Protestant, Catholic, and No Religion/Other Religion. Thirty-six percent of the sample are Protestant, and 28 percent are Catholic. Less than 2 percent are adherents of other religions, and 33 percent have declared having no religion. ${ }^{8}$ Thus, we have merged these last two groups into No Religion/Other Religion category.

\footnotetext{
${ }^{8}$ There are about 102,000 Jews in Germany, which is $0.13 \%$ of the 80 million population (http://de.statista.com/statistik/daten/studie/1232/umfrage/anzahl-der-juden-in-deutschland-seit-dem-jahr2003/)
} 
There are geographic patterns in religious denomination in Germany. While the South and West of the country are primarily Catholic, the North and central locations tend to be more heavily Protestant. Participation in religion was strongly discouraged in former East Germany and as a result, today most individuals in the eastern states of the country report not having a religion. For example, data from the 2011 German Census show that 62.9 percent of individuals from Saarland (located in the West) are Catholic, while only 6.2 percent of individuals from Schleswig-Holstein (the northernmost state) are Catholic. Schleswig-Holstein is 53.7 percent Protestant. Mecklenburg-Vorpommern is a formerly East German state bordering SchleswigHolstein, and in Mecklenburg-Vorpommern 79.1 percent of individuals have no religion. ${ }^{9}$

In some specifications we include a variable that measures the extent of the support of the National Socialist German Workers' Party (NSDAP, or Hitler's Nazi Party) in the state during the May 1928 elections. While the NSDAP earned only a small share of the overall votes in 1928, we use this election year because the party was most Anti-Semitic at that time, and thereafter toned down the rhetoric in order to appeal to a broader base of voters (Voigtlaender and Voth 2012a). Data, which are taken from King et al. (2008), are at the voting district level; districts as defined in 1928. We match the voting districts from 1928 with the current state boundaries in Germany. We then sum across all voting districts within each current state the number of valid votes cast, as well as the number of votes earned by the Nazi Party. This allows us to calculate the percent of the votes earned by the Nazi Party in 1928 for regions as defined by today's state lines. We then create a state level dummy variable that is equal to one if the state

\footnotetext{
${ }^{9}$ The reason for the geographic differences in religious denomination are largely rooted in history. After the Protestant Reformation in the 1500s, the rulers of the different territories of the Holy Roman Empire either chose to follow the Reformation or to remain Catholic. Areas where the rulers of that time chose to follow the Reformation are still largely protestant, and the predominantly Catholic areas today tended to have rulers that chose to remain Catholic.
} 
has a percentage of votes cast for the Nazi party in 1928 that is larger than the median, and is zero otherwise.

Each respondent lives in one of the 16 German states. ${ }^{10}$ Regressions control for state fixed-effects. They also control for year fixed-effects to account for the fact that we pool surveys from multiple years (See Table 1). The specifications that include the Nazi State in 1928 cannot include state fixed-effects because this variable does not change over time. In these models we also include variables that measure the age distribution of the state, percent foreigners living in the state and per capita GDP of the state.

\section{Empirical Framework and the Results}

We estimate models of the following form.

$$
\mathrm{R}_{i s}^{\mathrm{t}}=\beta_{0}+\beta_{1} \text { EconGood }_{i s}^{t}+\beta_{2} \text { EconBad }_{i s}^{t}+\mathbf{X}_{i s}^{\mathbf{t}} \boldsymbol{\Psi}+\mu_{\mathrm{s}}+\pi_{\mathrm{t}}+\boldsymbol{\varepsilon}_{i s}^{\mathbf{t}}
$$

where $\mathrm{R}_{\text {is }}^{\mathrm{t}}$ represents the extent of anti-Semitic, xenophobic and racist feelings of individual ( $i$ ) who resides in state $(s)$, who is surveyed in year $(t)$. EconGood and EconBad are mutually exclusive dummy variables to indicate if the person thinks his/her personal economic conditions are good/very good, or bad/very bad, respectively. The left-out category is personal economic conditions being neutral. Alternatively, we estimate equation (1) by using sentiments about National Economic Conditions, rather than Personal Economic Conditions. We also estimate models that include both personal and national economic conditions jointly. The vector $\mathrm{X}$

${ }^{10}$ The states are Schleswig-Holstein, Hamburg, Niedersachsen, Bremen, Nordrhein-Westfalen, Hessen, Rheinland-Pfalz, Baden-Württemberg, Bayern, Saarland, Berlin, Brandenburg, MecklenburgVorpommern, Sachsen, Sachsen-Anhalt, and Thüringen. 
incudes personal attributes of the respondent such as age, education, marital status, labor force activity, city size, and whether he/she lives in the inner city.

Benchmark models include state fixed-effects $\left(\mu_{\mathrm{s}}\right)$, as well year dummies $\left(\pi_{\mathrm{t}}\right)$ to account for the fact that surveys are administered in multiple waves in different years. City and state characteristics that vary over time are matched with the appropriate survey year. For example, those surveyed in 2006 are matched with city and state characteristics in 2006. Standard errors are clustered by age group-and-state of residence.

Table 3A presents the results of the estimated models where the dependent variables measure the extent of anti-Semitic and racist feelings. The dependent variable in column (1) takes the value of one if the respondent indicated that foreigners living Germany should only marry people of their own nationality. More educated individuals have a lower propensity for racism as measured by this question, and education has a monotonic effect: those with a vocational education are 8 percentage points less likely (in comparison to those with only the basic level of education) to indicate that foreigners should only marry people of their own nationality. Those with advanced technical education are about 14 percentage points less likely, and those with a college degree are about 18 percentage points less likely to agree with this racist statement. ${ }^{11}$ People who work in the labor market are about two percentage points less likely to agree with the statement, and people who live in cities that are larger than 100,000 residents are about 3 percentage points less likely to agree with it in comparison to those who live in smaller cities.

The first two explanatory variables in Table 3A show that, all else the same, people are about 3 percentage points less likely to agree that foreigners living Germany should only marry people of their own nationality if they believe that their personal economic conditions are good.

\footnotetext{
${ }^{11}$ Dustmann, Fabbri and Preston (2011) also find that higher education is associated with lower prejudice.
} 
On the other hand if they think that their personal economic conditions are bad, they are about 3 percentage points more likely to agree with the racist statement. The same result is obtained in the analysis of the statement "Foreigners living Germany should not be allowed to take part in any political activity." People who believe that their personal economic conditions are in good shape are less likely to agree with the statement and those with bad personal economic conditions are more likely to agree.

Columns (3) to (6) present the results of models where we analyze the determinants of anti-Semitism and racism targeted at specific groups. Column (3) is the model where the dependent variable is a dichotomous indicator of whether the respondents agreed with the statement that "Jewish people living in Germany should not have the same rights as other Germans in every respect." Columns (4) to (6) pertain to the same question targeted to ethnic Germans, originally from Eastern Europe, Turks, and Italians, respectively. The same regularity emerges in all models. The proclivity to declare that people should not have the same rights as Germans if they are Jewish, ethnic German, Turk or Italian goes down if the respondent's personal economic conditions are good, and the opposite is true if the respondent's economic conditions are bad. Using the coefficients across the models and using the baseline means of the dependent variables, we find that personal economic conditions being good reduces these racist feelings by 11 to 23 percent, and bad personal economic conditions enhances the racists feelings by 10 to 27 percent.

The estimated coefficients of other explanatory variables are consistent across models. Educated people are less racist. The propensity for racism is lower for people with no religious affiliation in comparison to Protestants (which is the left-out category). The impact of being a Catholic is no different than that of being a Protestant with the exception of the model in column 
(5), where being a Catholic increases the propensity to declare that Turks living in Germany should have not have the same rights as Germans by 3 percentage points in comparison to Protestants.

Table 3B presents the results where we analyze the determinants of a set of xenophobic and anti-Semitics attitudes. The questions are whether the respondent feels that it would be unpleasant to have a Jewish person (or an ethnic German, Turk or Italian) as a neighbor and whether it would be unpleasant if a Jewish person, an ethnic German, a Turk or an Italian were married into the family of the respondent. The results are consistent with those reported in Table 3A. If the respondent thinks that his/her personal economic conditions are good, this reduces the extent of anti-Semitic and xenophobic feelings. More education and being female have dampening effects on these feelings. Religious affiliation has no impact in these regressions with the exception of the impact on Turks. Columns (3) and (7) show that Catholics are more likely to indicate that it would be unpleasant to have a Turkish neighbor, and it would be unpleasant if a Turk married into the family. In column (7) we also show that those with no religion are less likely to indicate that it would be unpleasant if a Turkish person married into the family.

Age has a positive impact on racist feelings. To investigate the impact of age further, we re-estimated a more flexible form by including age dummies for 10 -year age intervals. The results, shown in Appendix Tables 1A-B, reveal that age has a monotonic impact on racist, antSemitic and xenophobic attitudes, where these feelings are stronger for older people. Given that we use data from various years between 1996 and 2010, those who are 65 and older have experienced the Nazi Germany and the World War II. The point estimates are larger for this group, which is consistent with the results of Voigtlaender and Voth (2012b), who report that 
cohorts that grew up under the Nazi regime are more anti-Semitic today. It is also interesting to note, however, that the age effect exists also among the younger cohorts: those who are 25-34 are more racist in comparison to those who are 18-24 (the left-out category in regressions of Appendix Tables 1A-B).

Tables $4 \mathrm{~A}$ and $4 \mathrm{~B}$ present the same regressions, but in these models we replace the variables that measure how the respondents feel about their personal economic circumstances with the variables that gauge how they feel about the current economic situation in Germany. The results in Tables 4A and 4B are similar to those reported in Tables 3A and 3B. The belief that current economic conditions in Germany are good (bad) has a diminishing (enhancing) effect on racist, xenophobic and anti-Semitic feelings. The impact is stronger, both in magnitude and statistical significance, when the person believes that the German economy is doing badly. ${ }^{12}$

The benchmark models do not include household income because income could be endogenous to racist attitudes. However, religious affiliation could be correlated with income, even conditional on education. Thus, we added household income to the models. The results, reported in Appendix Tables 3A and Appendix 3B show that all results remain the same although the impact of being Catholic becomes insignificant in some cases. Income has an additional negative impact on anti-Semitic, xenophobic and racist feelings.

\section{Contact with Foreigners and the Impact of the 1928 Nazi Vote}

In this sub-section we report the results of the models that include indicators of contact with foreigners. As predicted by the model of Glaeser (2005) having contact with minorities

\footnotetext{
${ }^{12}$ The models that include perceptions on both personal economic well-being and national economic conditions provided very similar results although in some cases the precision of the estimated coefficients were reduced. These results are reported in Appendix Table 2.
} 
should provide information about them and should alleviate xenophobic and racist feelings. It is also possible that racist and xenophobic people avoid contact with minorities. We address this potential reverse causality in a number of ways as explained in the Robustness section below.

It is easier to avoid contact with family members who are foreigners, but it is more difficult to avoid contact with foreigners in the place of work. That is, the extent of contact with foreigners at work may not be at full discretion of the individual. (In the robustness section we make use of the information on the self-employed). Thus, we add to the models a variable that gauges whether the respondent has contact with foreigners at work. Specifically, this dummy variable takes the value of one if the respondent answered in the affirmative to the following question: "Do you have personal contact with foreigners living in Germany at your job?" The results are reported in Table 5A for comparison. The top panel of Table 5A displays the main results reported in Table 3A. For brevity, we only show the coefficients of Good Personal Economic Conditions and Bad Personal Economic Conditions. Panel B of Table 5A displays the results of the regressions which also include the variable that measures contact with foreigners at work. There are two key observations. First, the variable Foreign Contact at Work is negative and highly significant in each model, suggesting that those who have contacts with foreigners at work have less racist tendencies. Second, inclusion of the contact variable has no meaningful impact on the magnitude of the coefficients of the personal economic conditions.

In panel $\mathrm{C}$ of Table 5A we report the results of the specifications that include two additional variables: Foreign Contact in Family and Nazi State in 1928. The former variable measures whether the respondent has personal contact with foreigners living in Germany through his/her own family or other immediate relatives. Nazi state in 1928 is a dichotomous variable that takes the value of one if the Nazi party has received more than the median vote in 
respondent's state in 1928. The regressions behind Panel C of Table 5A include every variable that is included in all previous regressions with the exception of state fixed effects. The reason for this is the fact that the variable Nazi State in 1928 does not vary within states. Therefore, the regressions in Panel C include some other state-level variables (that vary over time), such as the proportion of people in various age groups in the state, state per capita GDP and the proportion of state population that is foreigners. A comparison of panels B and C of Table 5A shows that adding these variables has no impact on the coefficients of economic condition variables or on the coefficients of Foreign Contact at Work. In addition, the estimated coefficients of Foreign Contact in Family are always negative and highly significant suggesting that contact with foreigners through family or immediate relatives mitigates racist feelings.

Those who live in states which provided above-median support for the Nazi Party in the 1928 elections are about 7 percentage points more likely to reveal that Jewish people living in Germany should not have the same rights as Germans. This result is in line of that reported by Voigtlaender and Voth (2012b). They show that historical voting patterns for anti-Semitic parties between 1890 and 1933 are strong predictors of anti-Jewish attitudes in Germany today. ${ }^{13}$ The states where the Nazi Party received above-median votes in the 1928 elections are SchleswigHolstein, Hamburg, Niedersachsen, Hessen, Rheinland-Pfalz, Bayern, Sachsen, and Thüringen. These states are located all throughout Germany. For example, Schleswig-Holstein is in the North, bordering Denmark, whereas Bayern is in the South, bordering Austria and the Czech Republic. Thüringen is in the middle of Germany with no borders to other countries. There is also significant variation in their population size, ranging from small states such as

\footnotetext{
${ }^{13}$ They also show that anti-Semitism is stronger among the cohort that grew up under the Nazi regime and that different zones of Germany, occupied by different countries after the WW II, exhibit different patterns of anti-Semitism.
} 
Hamburg and Thüringen with about 2 million residents in 2010 to Bayern with about 13 million people and Niedersachsen with 8 million residents. More importantly, there is no correlation between the current level of development in a state and voting outcomes in 1928. The correlation coefficient of a dummy variable indicating a higher than national median vote for the Nazi party in 1928 and state-level GDP per capita in 2009 is 0.15 . Thus, it is unlikely that the Nazi State in 1928 variable is capturing an economic aspect of the states.

Table 5B is similar to Table 5A, but here we analyze the feelings regarding "unpleasantness" of neighbors who are foreigners, Jewish or ethnic German (Aussiedler), and "unpleasantness" of them marrying into the family. These are the extensions of the regression reported in Table 3B, where the contact variables and Nazi state in 1928 are added as additional regressors. Panel A of Table 5B re-displays the coefficients of the benchmark model reported in Table 3B. Panel B reports the coefficients of the models that include Foreign Contact at Work, and Panel C displays the results of the models that include Foreign Contact at Work, Foreign Contact in Family and Nazi State in 1928. The results are in line with those reported in Table 5A. Adding variables that measure contact with foreigners and the Nazi State in 1928 does not impact the magnitude of the economic condition variables. The contact variables are always negative and significant, suggesting that having contact with foreigners alleviates the extent of anti-Semitic and xenophobic feelings. Panel C of Table 5B shows that those who live in states that have casted above-median Nazi-Party votes in 1928 are about 3 percentage points more likely to indicate that "it would be unpleasant to have a Jewish neighbor."

It is interesting to note that the Nazi State in 1928 is statistically significant only in the outcomes that measure anti-Semitism: "Jewish people living in Germany should not have the same rights as Germans" and "It would be unpleasant to have a neighbor who is Jewish." (Panel 
C, column 3 of Table 5A, and Panel C, column 1 of Table 5B.) This finding suggests that whatever anti-Semitic culture that existed in 1928 in those states, it still has an impact on antiSemitic feelings today. It is of course possible that those with anti-Semitic feelings migrate from other parts of Germany to those states that have provided strong support for the Nazi Party in 1928. Even if this phenomenon is prevalent, it would still underline the persistence in antiSemitism and the prevalence of some state-wide anti-Semitic attitude that would attract such people to those states.

\section{$\underline{\text { IV. Extensions and Robustness }}$}

Intense Dislike of "Others"

So far we have investigated the determinants of attitudes targeted towards specific groups, such as Jewish people or ethnic Germans as well as attitudes towards minorities as a group. In this section we identify strong racists and investigate if economic well-being has an impact on racist attitudes among this group of people.

We create three new variables. Intense Dislike of Foreigners is dichotomous variable that takes the value of one if the respondent indicated that "Foreigners living in Germany should only marry people of their own nationality," and if they also agreed with the statement that "Foreigners living in Germany should not be allowed to take part in any political activity." As Table 1 shows, 18 percent of the sample agreed with the former statement and 28 percent agreed with the latter. The mean of Intense Dislike of Foreigners is 0.105 , meaning that about 11 percent of the respondents agreed with both of these statements.

Intense Dislike of Equal Rights intends to gauge stronger racist feelings. To qualify for Intense Dislike of Equal Rights, one has to agree with the following five statements: "Foreigners 
living in Germany should not be allowed to take part in any political activity," "Jewish people living in Germany should not have the same rights as Germans," "Ethnic Germans from Eastern Europe living in Germany should not have the same rights as Germans, "Italians living in Germany should not have the same rights as Germans," and "Turkish people living in Germany should not have the same rights as Germans." Slightly less than seven percent of the sample agreed with these five statements.

Intense Dislike of Intermarriage takes the value of one if the individual believes that "Foreigners living in Germany should only marry people of their own nationality," and in addition, he/she feels that it would be unpleasant if either a Jewish person, or a Turk, an Italian or an ethnic German married into their family. About 5 percent of the sample feels this strongly negative about intermarriage.

Table 6 reports the summary results of the regressions using three types of strong racist feelings. All models in Panels A and B include all variables that are included in Table 3A, including state fixed-effects and year dummies. Panel C includes the same variables with the exception of state state-fixed effects. Instead of state fixed-effects these models include state attributes as was the case in Panels $\mathrm{C}$ of Tables 5A and 5B. In all cases we observe that racist attitudes are subdued when the person thinks his/her personal economic conditions are good, and they are intensified when personal economic conditions are bad. The impact of bad personal economic conditions is two-to-three three times as strong as the impact of good economic conditions. 


\section{Models that Exclude Individuals with Strong Racist Attitudes}

To investigate if the results are sensitive to the exclusion of those with strong racist attitudes we dropped from the sample those individuals for whom Intense Dislike of Intermarriage is equal to one or Intense Dislike of Equal Rights is equal to one. This exercise eliminates strong racists from the sample and allows us to investigate whether economic wellbeing still has an impact on anti-Semitics, xenophobic and racist attitudes in the rest of the sample. The results, summarized in Tables 7A and 7B, demonstrate that all previous results hold: If the respondent believes that his/her personal economic conditions are good, racist xenophobic and anti-Semitic feelings are lessened, and the reverse is true if they feel negatively about their economic well-being. Having contact with foreigners has a positive impact and those in states that have casted strong Nazi Party vote in 1928 are more anti-Semitic.

\section{The Impact of Sector of Work and Self-Employment}

The models estimated so far include a variable that measures whether the person is working in the labor market. We also estimate models that introduce detailed job classification for those who work. Specifically, in the data set each individual is classified into a job classification such as self-employed farmer, self-employed professional, other self-employed, civil servant or member of the military, laborer, employee (non-laborer), and trainee. As Table 2 shows $56 \%$ of the sample is working in the labor market (non-workers include students, homemakers, retired people as well as those who are otherwise not in the labor force). Table 2 also shows that we have information on sector of work for $52 \%$ of the sample, indicating that some workers have not provided information about their type of work. 
Tables $8 \mathrm{~A}$ and $8 \mathrm{~B}$ display the result of the models that include the variables on sector of work. These are the same models as in benchmark models of Tables $3 \mathrm{~A}$ and 3B, but the variable Worker is replaced by variables identifying employment category. The results show that laborers and self-employed farmers have stronger xenophobic, anti-Semitics and racist feelings in comparison to those who are not in the labor force. Civil servants and self-employed professionals seem to have weaker racist feelings. Note that these results emerge despite the fact that the models control for the impact of education. Other results, including the impact of economic well-being, are consistent with those reported earlier. Some coefficients are not reported in Tables $8 \mathrm{~A}$ and $8 \mathrm{~B}$ and they are consistent with previous results as well. For example, as in all previous models, men have consistently stronger racist attitudes. The specifications that include the Nazi State in 1928 variable showed that this variable is significant in explaining antiSemitic feelings as reported in earlier regressions. The impact of religion, displayed in Tables 3A-4B is the same in these models as well. We also ran these models by excluding non-workers. In these models we used the "Employee" category as the left-out comparison group. We found the same results: Self-employed farmers and laborers have stronger racist feelings than employees, and civil servants and self-employed professionals have weaker racist feelings.

It is possible that those with stronger negative feelings towards "others" decide to become self-employed to avoid contact with foreigners and with those of other ethnic or religious backgrounds. The data, however, do not support this hypothesis as the mean value of Foreign Contact at Work is 0.48 among the self-employed and it is 0.37 among those who are not self-employed. Similarly, the rate of Foreign Contact in Family is higher among the selfemployed (26\% vs. $18 \%$ ); and both of these differences are statistically significant. Nevertheless, we dropped all self-employed individuals and re-estimated the models. The 
summary of the results, obtained from this sample of non-self-employed workers are reported in Tables 9A and 9B. The results are very similar to those reported earlier, including the coefficients of "Foreign Contact" at work and in family, indicating that the results are not sensitive to the exclusion of the self-employed from the analysis.

\section{Are the Results Gender-specific?}

To investigate if these results are driven my males or females, we re-estimated the entire set of regressions using only males or only females. Appendix Table 4 displays the descriptive statistics of the dependent variables by gender. The mean values of the variables are very similar between sexes. Appendix Tables 5A-5B and Appendix Tables 6A-6B display the results estimated in male- and female samples, respectively. There is remarkable similarity in the results. The point estimates are similar in both samples. For both males and females, good economic conditions have a dampening effect on racist, anti-Semitic and xenophobic feelings and bad economic conditions strengthen these feelings.

Are the Results driven by Males' Frustration about "Lack of Job Priority for German Men”?

Although Appendix Tables 4A-5B show that the results are not driven by gender differences, it could be the case that in case of men, the relationship between economic conditions and racist, anti-Semitic and xenophobic feeling could be a reflection of men's concern about economic conditions and their perceptions of "men's priority in the job market." More specifically, assume that German men get upset about not having sufficient job opportunities for them during economically difficult times and they blame "others" for such lack of opportunity. 
Under this scenario, this frustration would manifest itself in having negative attitudes towards "all others," including women.

To test this hypothesis we use five questions from the survey that gauge attitudes toward women's employment in the labor market and responsibilities at home. The descriptions of these variables are provided below. The survey asks the respondents whether they strongly disagree, disagree, agree, or strongly agree with each of these statements. We coded each variable as one if the respondent agreed or strongly agreed with the statement. In this analysis we use only men and the mean value of men's agreement with each statement is provided following the variable description below.

It is more important for a woman to help husband's career than have a career herself (mean=0.26), An infant will certainly suffer if the mother is working in the market (mean=0.61), It is better if a husband works and the wife stays at home tending to household and children (mean=0.39), It is not good for a child if the mother is working in the market instead of just concentrating on the household (mean $=0.51),{ }^{14}$ A married woman should give up working if jobs are scarce and husband can provide for family (mean=0.37).

We ran the models using men only, replacing the variables measuring racism, antiSemitism and xenophobia with the variables that gauge attitudes towards women's work. The results, displayed in Table 10, show that economic conditions have no impact on men's attitudes toward women's attachment to the labor market or on women's responsibilities at home. This indicates that men's perceptions of economic well-being do not trigger across-the-board reactions toward all others (in this case, women) who may be competing with men for jobs. Rather, economic well-being alters racist, anti-Semitic and xenophobic feelings.

\footnotetext{
${ }^{14}$ This question was asked in converse as "It is actually good for a child if the mother is working in the market instead of just concentrating on the household." For consistency with other questions, we reversed the question and the answers.
} 
Are the Results due to Directly "Being Upset About Job Scarcity Because of Foreigners"?

When economic well-being or the perception of economic well-being declines, individuals could be hostile towards foreigners on the grounds that foreigners are taking away jobs from natives. If this job market-related sentiment is strong enough, it could trigger racist and xenophobic feelings. Under this scenario, racist feelings are a by-product of fears about job loss because of foreigners, and not a direct consequence of economic well-being.

Note that this conjecture pertains to natives being fearful about the scarcity of jobs, and therefore reacting negatively towards foreigners in a variety of ways, ranging from revealing displeasure to having them as neighbors to trying to prevent them from marrying anyone other than their own nationality. Because German Jews and German ethnic minorities (Aussiedler) are not foreigners, job and wage-related fear should not trigger racism or anti-Semitism against these groups. If it does, his could be an indication of behavior along the lines suggested by Loewenstein (2000). For example, Card and Dahl (2011) and Rees and Schnapel (2009) show that an unexpected loss of a football game triggers violence by men against women, suggesting the importance of reference points in behavior (DellaVigna 2009).

To investigate this hypothesis, we utilized a question in the German Social Survey that was used to ask the respondents the extent to which they agreed/disagreed with the statement that "When jobs get scarce, foreigners living in Germany should be sent home." About 26 percent of the sample agreed or strongly agreed with this statement, and for this group the variable Kick Out Foreigners when Jobs are Scarce takes the value of one. Regression results that include this additional variable are presented in Appendix Tables 7A and 7B. They are counterparts to Tables 3A and 3B. Table Appendix 6A shows that the coefficient of Kick out Foreigners when 
Jobs are Scarce is always positive and different from zero. Having this variable in the regression reduces the impact of economic conditions on racist, anti-Semitic and xenophobic feelings, but it does not eliminate it. The reduction in the magnitude of the coefficients is sometimes sizable. For example, the coefficient of Good Personal Economic Conditions in the model reported in column (1) of Table 3A - where the dependent variable is "Foreigners should marry only people of their own nationality" is -0.0272 , and it is -0.0111 when the model includes the variable Kick out Foreigners when Jobs are Scarce (in column (1) of Appendix Table 7A). This suggests that part, but not all, of the impact of economic well-being on racist attitudes is driven by concerns about competition with foreigners for jobs. It is interesting to note that the impact of economic well-being gets smaller also in regressions about anti-Semitic attitudes, and attitudes against ethnic Germans (columns 3 and 4), although the decline in magnitude is not as significant as in columns (1) and (2). This suggests that fears about job security trigger anti-Semitic and racist reactions, much like an unexpected loss of a football match triggers violence against women (Card and Dahl 2012). Nevertheless, controlling for the sentiment about sending foreigners off when jobs are scarce does not eliminate the impact of economic well-being on xenophobic, anti-Semitic and racist attitudes.

\section{$\underline{\text { V. Conclusion and Discussion }}$}

Recent research in economics has demonstrated that cultural attributes of individuals have significant impact on their economic behavior. While culture consists of many dimensions, certain attributes of a society, such as people's beliefs about the importance of the family, and whether people of a given country trust or distrust people from other countries have been used as indicators of culture (Alesina and Giuliano 2010, Bottazzi et al. 2011, Helliwell et al. 2014). 
Cultural traits of countries, such as distrust of others, are believed to be very stable; i.e. they change very slowly from generation to generation. This implies that culture has persistent, longlasting impacts on behavior. On the other hand, economic conditions of individuals are shown to have an impact even on strong feelings, such as vengeance (Mocan 2013).

In this paper we use data from Germany to investigate the extent to which attitudes of Germans towards foreigners, Jews and ethnic Germans are impacted by personal characteristics of the respondents as well as the extent to which they believe that their personal economic circumstances or the economic conditions in Germany are good or bad.

The questions posed to Germans in the data set gauge the extent of anti-Semitic, xenophobic and racist feelings. They range from statements about foreigners such as "Foreigners should not be allowed to marry anyone other than their own nationality," to statements about a specific group such as "Jews in Germany should not have the same rights as other Germans," or "It would be unpleasant to have a Turkish person as a neighbor." Note that "foreigners" does not refer to illegal immigrants because illegal immigration is practically nonexistent in Germany. Instead, foreigners in the survey questions refer to non-Germans who are legal residents of Germany (such as guest workers or citizens of other EU countries). Similarly, "Jews" does not refer to citizens of Israel, but it refers to Jewish German citizens.

A variety of empirical specifications yield very consistent results. Consistent with theoretical predictions of Glaeser (2005), education weakens anti-Semitic, xenophobic and racist feelings, and higher levels of education are associated with monotonically lower level of negative feelings. Those who have contact with foreigners at work or through family have weaker racist feelings. These results are not driven by selection into self-employment and the results hold among strong racists as well as those who have weaker racist feelings. 
Negative feelings towards religious and ethnic minorities (Jews, or Aussiedler) and towards foreigners are not substantially different between Protestants and Catholics although there is evidence of negative feelings of Catholics towards Turks, who are, by and large, Muslim. Non-religious Germans have weaker negative feelings towards foreigners, Jews and ethnic Germans. Controlling for household income does not alter the results.

Voigtlaender and Voth (2012a) find that the extent of anti-Semitism 600 years ago, measured by persecutions and executions of Jews during the plague-era, predicts the extent of support of the Nazi Party in the 1928 elections in Germany. This suggests that anti-Semitic sentiments continued to exist in local areas for centuries. We extend on this idea and include in our specifications a measure of local support for the Nazi Party in 1928. Economic conditions of the German states today are not correlated with whether they were more supportive of the Nazi Party in the 1928 elections. We find that people who currently reside in states that have provided above-median support for the Nazi Party in 1928 are more anti-Semitic today in comparison to those who live elsewhere. This provides evidence that local cultural traits in terms of antiSemitism persisted over the last 80 years. ${ }^{15}$

Importantly, we find that people's perceptions of their economic circumstances have an impact on their anti-Semitic, xenophobic and racist feelings. The data set contains questions on the respondents' evaluation of their own economic situation, and how they rate the current economic conditions in Germany. We find that, xenophobic, anti-Semitic and racist feelings are mitigated when people believe that their own economic situation is in good shape, and these feelings are magnified when people think that their personal economic situation is bad. The results are the same regardless of whether we use individuals' assessment of their personal

\footnotetext{
${ }^{15}$ This point in also made by Voigtlaender and Voth (2012b).
} 
economic well-being or the economic well-being of Germany. The results are similarly robust to using these measures jointly and also adding household income to the models.

We show that very similar results are obtained when men and women are analyzed separately. It could still be the case that the relationship between economic conditions and racist, anti-Semitic and xenophobic feelings is a reflection of men's frustration about the job market in general, which then produces negative reactions against anyone who would compete for jobs, including women. We analyze men's responses to statements such as “A married woman should give up working if jobs are scarce and husband can provide for family," and "It is better if the husband works and wife stays at home tending to household and children," and find that economic conditions have no impact on men's attitudes towards women's attachment to the labor market. This indicates that perceptions about economic well-being do not trigger acrossthe-board negative reactions stemming from job insecurity.

These results suggest that economic well-being of individuals influence how they perceive others who are "different" from them. More specifically, the negative/intolerant/prejudiced feelings about minorities are mitigated if economic well-being is improved. These results are consistent with the model proposed by Akerlof and Kranton (2000, 2005) that underline the importance of identity in economic behavior and suggest that income (economic well-being) and identity are substitutes.

The results are important for a number of reasons. For example, the rise in international labor mobility and migration over the last two decades has made domestic populations more heterogeneous in many countries and changed the landscape of labor markets. This phenomenon created debates ranging from job displacement of natives of the country by foreigners, to whether or not the inflow of the immigrants has an impact on economic productivity in the 
receiving country. A parallel debate centers around the extent to which immigrants adopt the mainstream lifestyle of the country to which they migrated, and economic and social problems that may have been generated by the presence of immigrants. A few recent and prominent examples include the debate on a law banning veils and other face coverings in public places (mostly applicable for Muslim immigrants) in France, the debate on the relationship between illegal immigration and crime in the United States.

Nevertheless, the trend of the change in the demographic composition of many developed countries, and the associated repercussions are expected to continue. ${ }^{16}$ For example, the U.K. and eight other European Union countries have lifted restrictions in 2014 for Bulgarians and Romanians to work and reside in their countries. But, the expectation of Bulgarians and Romanians to move to the U.K. has created political turmoil that included comments of Prime Minister David Cameron against the predicted jump in migration on the one hand, and the warnings of the EU officials against "knee-jerk xenophobia" on the other hand (The Guardian; March 30, 2013); and the EU Commission President Jose Manuel Barroso warned EU countries against nationalism, xenophobia and racism (Reuters, October 30, 2013). In February 2014 a referendum in Switzerland supported a quota on immigration, spearheaded by the right-wing

\footnotetext{
${ }^{16}$ It is predicted that 55 percent of the U.S. population will consist of African-Americans and those with Hispanic or Asian descent (U.S. Census Bureau). Populations of the EU countries are becoming more heterogeneous as well. A visible example of the inflow of foreigners and increased prevalence of secondgeneration immigrants in Europe can be seen in the soccer industry. In 1990, the prominent German soccer team Bayern Munich had three players on its 22-player roster who were not German (13.6\% of the roster). In 2013, almost half of the Bayern roster (46\%) consisted of foreign players. The same is true for any other soccer team in Europe. For example, the share of foreign players rose from 19\% in 1990 to 33\% in 2013 for the prominent Spanish soccer team Barcelona. The picture is even more striking regarding the national soccer teams. A player must have citizenship of that country to be eligible to play on the national team. In 1990, the French national soccer team had two black French players (14\% of 25 players). In 2013 the same team includes 9 black players (41\% of 22 players). German national soccer team had no player who was not of German descent in 1990. The team has 8 players in 2013 that have a migration background.
} 
Swiss People's party (SVP), prompting a reaction from the EU leaders, including German Chancellor Angela Merkel (Reuters, February 18, 2014).

Attitudes towards "others" have economic implications. For example, racist and xenophobic attitudes are likely to have discriminatory effects in a number of markets including the labor market, housing market and the money market with consequences on wage disparities, credit constraints and economic mobility. Such attitudes would also yield to under-utilization of resources and loss of productivity. An example is provided by Freeman and Huang (2014) who show that homophily in research collaborations generates weaker scientific contributions. Similarly, Hong and Page (2004) show theoretically that a team of randomly selected agents from a diverse population outperforms a homogenous team of high ability agents. The intuition is that within-group diversity in perspective and problem solving becomes more important than average group ability. Lazear (1999) discusses that a multi-cultural team in a corporate environment, which combines workers of different cultures and exploits worker complementarities, could have a positive impact on productivity although costly communication can pose a constraint. On the other hand, ethno-linguistic fragmentation of a population can generate challenges regarding governance, especially if the institutions are weak. A more detailed discussion of costs and benefits of diversity is provided by Alesina and La Ferrara (2005).

Although the impact of perceived economic conditions on racist attitudes becomes smaller in some cases when we control for the sentiment that foreigners should be sent home when jobs get scarce, it does not vanish. This indicates that job-related fears are not the only or even principal source of the racist and xenophobic attitudes. Furthermore, controlling for the foreigner-induced job-related fears reduces the impact of economic well-being on anti-Semitic 
and racist feelings towards Jews and German ethnic minorities (Aussiedler), both of whom are German citizens. This provides some support for the potential importance of reference points in behavior, similar to that of Card and Dahl (2011) who report that an unexpected loss of a football game triggers violence against women.

In summary, our results show that xenophobic and racist reactions against "others" from foreign countries and cultures are alleviated when people feel more secure about their economic conditions and that, more generally and more importantly, perceived economic circumstances of people have an impact on feelings as strong as anti-Semitism and racism. 
Table 1. Descriptive Statistics of Outcome Variables

\begin{tabular}{|c|c|c|c|c|c|}
\hline Variable & Details & $\begin{array}{c}\text { Years } \\
\text { available }\end{array}$ & Mean & $\begin{array}{l}\text { Std. } \\
\text { Dev. }\end{array}$ & $\mathrm{N}$ \\
\hline $\begin{array}{l}\text { Foreigners Should } \\
\text { Marry Their Own }\end{array}$ & $\begin{array}{l}\text { "Foreigners living in Germany should } \\
\text { choose to marry people of their own } \\
\text { nationality." }\end{array}$ & $\begin{array}{l}1996,2000 \\
2002,2006 \\
2010\end{array}$ & 0.180 & 0.384 & 13,146 \\
\hline $\begin{array}{l}\text { No Politics for } \\
\text { Foreigners }\end{array}$ & $\begin{array}{l}\text { "Foreigners living in Germany should be } \\
\text { prohibited from taking part in any kind of } \\
\text { political activity" }\end{array}$ & $\begin{array}{l}1996,2000 \\
2002,2006 \\
\quad 2010\end{array}$ & 0.283 & 0.450 & 13,102 \\
\hline $\begin{array}{l}\text { No equal rights for } \\
\text { Jews }\end{array}$ & $\begin{array}{l}\text { "Jewish people living in Germany should not } \\
\text { have the same rights as Germans in every } \\
\text { respect." }\end{array}$ & 1996, 2006 & 0.224 & 0.417 & 5,905 \\
\hline $\begin{array}{l}\text { No equal rights for } \\
\text { Aussiedler }\end{array}$ & $\begin{array}{l}\text { "Ethnic Germans from Eastern Europe living } \\
\text { in Germany should not have the same rights } \\
\text { as Germans in every respect." }\end{array}$ & 1996, 2006 & 0.282 & 0.450 & 6,100 \\
\hline $\begin{array}{l}\text { No equal rights for } \\
\text { Turks }\end{array}$ & $\begin{array}{l}\text { "Turkish people living in Germany should } \\
\text { not have the same rights as Germans in every } \\
\text { respect." }\end{array}$ & 1996, 2006 & 0.450 & 0.498 & 6,090 \\
\hline $\begin{array}{l}\text { No equal rights for } \\
\text { Italians }\end{array}$ & $\begin{array}{l}\text { "Italians living in Germany should not have } \\
\text { the same rights as Germans in every } \\
\text { respect." }\end{array}$ & 1996,2006 & 0.261 & 0.439 & 6,096 \\
\hline $\begin{array}{l}\text { Unpleasant Neighbor } \\
\text { - Jewish }\end{array}$ & $\begin{array}{l}\text { "It would be unpleasant to have a Jewish } \\
\text { person as a neighbor" }\end{array}$ & 1996, 2006 & 0.122 & 0.327 & 6,024 \\
\hline $\begin{array}{l}\text { Unpleasant Neighbor } \\
\text { - Aussiedler }\end{array}$ & $\begin{array}{l}\text { "It would be unpleasant to have an ethnic } \\
\text { German from Eastern Europe as a neighbor" }\end{array}$ & 1996,2006 & 0.227 & 0.419 & 6,134 \\
\hline $\begin{array}{l}\text { Unpleasant Neighbor } \\
\text { - Turkish }\end{array}$ & $\begin{array}{l}\text { "It would be unpleasant to have a Turkish } \\
\text { person as a neighbor" }\end{array}$ & 1996,2006 & 0.393 & 0.488 & 6,141 \\
\hline $\begin{array}{l}\text { Unpleasant Neighbor } \\
\text { - Italian }\end{array}$ & $\begin{array}{l}\text { "It would be unpleasant to have an Italian } \\
\text { person as a neighbor" }\end{array}$ & 1996,2006 & 0.074 & 0.261 & 6,141 \\
\hline $\begin{array}{l}\text { Unpleasant Marriage } \\
\text { - Jewish }\end{array}$ & $\begin{array}{l}\text { "It would be unpleasant if a Jewish person } \\
\text { married into my family" }\end{array}$ & 1996,2006 & 0.258 & 0.437 & 5,985 \\
\hline $\begin{array}{l}\text { Unpleasant Marriage } \\
\text { - Aussiedler }\end{array}$ & $\begin{array}{l}\text { "It would be unpleasant if an ethnic German } \\
\text { from Eastern Europe married into my } \\
\text { family" }\end{array}$ & 1996,2006 & 0.307 & 0.461 & 6,107 \\
\hline $\begin{array}{l}\text { Unpleasant Marriage } \\
\text { - Turkish }\end{array}$ & $\begin{array}{l}\text { "It would be unpleasant if a Turkish person } \\
\text { married into my family" }\end{array}$ & 1996,2006 & 0.554 & 0.497 & 6,111 \\
\hline $\begin{array}{l}\text { Unpleasant Marriage } \\
\text { - Italian }\end{array}$ & $\begin{array}{l}\text { "It would be unpleasant if an Italian person } \\
\text { married into my family" }\end{array}$ & 1996,2006 & 0.176 & 0.381 & 6,120 \\
\hline
\end{tabular}




\section{Table 1 (concluded)}

\begin{tabular}{|c|c|c|c|c|c|}
\hline $\begin{array}{l}\text { Intense Dislike of } \\
\text { Foreigners }\end{array}$ & $\begin{array}{l}\text { Individual thinks that foreigners should } \\
\text { choose to marry people of their own } \\
\text { nationality and that any kind of political } \\
\text { participation for foreigners should be } \\
\text { prohibited }\end{array}$ & $\begin{array}{c}1996,2000 \\
2002,2006, \\
2010\end{array}$ & 0.105 & 0.306 & 13,029 \\
\hline $\begin{array}{l}\text { Intense Dislike of } \\
\text { Equal Rights }\end{array}$ & $\begin{array}{l}\text { Individual thinks any kind of political } \\
\text { participation for foreigners should be } \\
\text { prohibited, and that neither Jews, Turks, } \\
\text { Italians, or Aussiedler should have the same } \\
\text { rights as Germans }\end{array}$ & 1996,2006 & 0.064 & 0.245 & 5,864 \\
\hline $\begin{array}{l}\text { Intense Dislike of } \\
\text { Intermarriage }\end{array}$ & $\begin{array}{l}\text { Individual thinks that foreigners should } \\
\text { choose to marry people of their own } \\
\text { nationality and that a Jew, Turk, Italian, or } \\
\text { Aussiedler marrying into their family would } \\
\text { be unpleasant. }\end{array}$ & 1996,2006 & 0.050 & 0.217 & 5,954 \\
\hline
\end{tabular}

See the text for detailed description of the variables and their measurement. 
Table 2. Descriptive Statistics of Demographic Variables and Local Area Characteristics

\begin{tabular}{|c|c|c|c|c|}
\hline Variable & Details & Mean & $\begin{array}{l}\text { Std. } \\
\text { Dev. }\end{array}$ & $\mathrm{N}$ \\
\hline Age & Age of the respondent & 48.743 & 17.103 & 13,146 \\
\hline Married & Dummy variable (Married = 1) & 0.604 & 0.489 & 13,146 \\
\hline Female & Gender dummy variable. Female $=1$ & 0.511 & 0.500 & 13,146 \\
\hline Education & Highest level of schooling attained & & & \\
\hline Minor & No formal education beyond basic secondary school & 0.180 & 0.384 & 13,146 \\
\hline Vocational & Completed apprenticeship & 0.478 & 0.500 & 13,146 \\
\hline Advanced Technical & Degree from advance trade or technical school & 0.182 & 0.386 & 13,146 \\
\hline College Degree & $\begin{array}{l}\text { Individual has a degree from a research university } \\
\text { or a university of applied science }\end{array}$ & 0.161 & 0.367 & 13,146 \\
\hline \multicolumn{5}{|l|}{ Religion } \\
\hline Protestant & & 0.363 & 0.481 & 13,146 \\
\hline Catholic & & 0.280 & 0.449 & 13,146 \\
\hline $\begin{array}{l}\text { No Religion/Other } \\
\text { Religion }\end{array}$ & & 0.357 & 0.479 & 13,146 \\
\hline Working & Dummy variable (=1 if currently working) & 0.563 & 0.496 & 13,146 \\
\hline Household Income & Real net monthly household income (1000s) & 2.170 & 1.385 & 10,573 \\
\hline $\begin{array}{l}\text { Personal Economic } \\
\text { Conditions }\end{array}$ & $\begin{array}{l}\text { Answer to the question: "How would you generally } \\
\text { rate your own current economic situation?" }\end{array}$ & & & \\
\hline Good & & 0.490 & 0.500 & 13,146 \\
\hline Neutral & & 0.377 & 0.485 & 13,146 \\
\hline $\mathrm{Bad}$ & & 0.132 & 0.339 & 13,146 \\
\hline $\begin{array}{l}\text { National Economic } \\
\text { Conditions }\end{array}$ & $\begin{array}{l}\text { Answer to the question: "How would you generally } \\
\text { rate the current economic situation in Germany?" }\end{array}$ & & & \\
\hline Good & & 0.188 & 0.391 & 13,110 \\
\hline Neutral & & 0.499 & 0.500 & 13,110 \\
\hline $\mathrm{Bad}$ & & 0.313 & 0.464 & 13,110 \\
\hline Contact with Foreigners & Individual has personal contact with foreigners... & & & \\
\hline At Work & & 0.382 & 0.486 & 12,834 \\
\hline In their own family & & 0.199 & 0.399 & 12,830 \\
\hline
\end{tabular}


Table 2 (concluded)

\begin{tabular}{|c|c|c|c|c|}
\hline \multirow{2}{*}{$\begin{array}{l}\text { City Size } \\
\qquad 0-49,999\end{array}$} & \multicolumn{4}{|l|}{ The size of the city where the respondent lives. } \\
\hline & & 0.381 & 0.486 & 13,146 \\
\hline \multicolumn{2}{|l|}{$50,000-99,999$} & 0.087 & 0.281 & 13,146 \\
\hline \multicolumn{2}{|c|}{$100,000-499,999$} & 0.227 & 0.419 & 13,146 \\
\hline \multicolumn{2}{|l|}{$500,000+$} & 0.305 & 0.460 & 13,146 \\
\hline Inner City & $\begin{array}{c}\text { Dummy ( }=1 \text { if the respondent live in the inner city, } \\
=0 \text { if suburb) }\end{array}$ & 0.381 & 0.486 & 13,146 \\
\hline \multicolumn{2}{|r|}{ Worker classification of the individual } & & & \\
\hline Non-worker & The person is retired, homemaker, a student, etc. & 0.472 & 0.499 & 12,723 \\
\hline \multicolumn{2}{|c|}{ Self-employed farmer } & 0.005 & 0.072 & 12,723 \\
\hline \multicolumn{2}{|c|}{ Self-employed Professional } & 0.009 & 0.095 & 12,723 \\
\hline \multicolumn{2}{|c|}{ Other self-employed } & 0.050 & 0.217 & 12,723 \\
\hline \multicolumn{2}{|c|}{ Civil Servant or military } & 0.035 & 0.183 & 12,723 \\
\hline \multicolumn{2}{|l|}{ Employee } & 0.265 & 0.441 & 12,723 \\
\hline \multicolumn{2}{|l|}{ Laborer } & 0.149 & 0.356 & 12,723 \\
\hline \multicolumn{2}{|l|}{ In Training } & 0.016 & 0.124 & 12,723 \\
\hline State Age Group & \multicolumn{4}{|l|}{$\begin{array}{l}\text { Share of the state's population in the age group as a } \\
\text { proportion of a state's total population. }\end{array}$} \\
\hline \multicolumn{2}{|l|}{$0-6$ years } & 5.279 & 1.018 & 10,375 \\
\hline \multicolumn{2}{|l|}{$6-18$} & 12.815 & 1.727 & 10,375 \\
\hline \multicolumn{2}{|l|}{$18-25$} & 8.184 & 0.680 & 10,375 \\
\hline \multicolumn{2}{|l|}{$25-30$} & 6.352 & 1.009 & 10,375 \\
\hline \multicolumn{2}{|l|}{$30-50$} & 30.838 & 1.076 & 10,375 \\
\hline \multicolumn{2}{|l|}{$50-65$} & 18.941 & 0.852 & 10,375 \\
\hline \multicolumn{2}{|l|}{65 plus } & 17.594 & 2.142 & 10,375 \\
\hline Percent Foreign & Percent of foreigners in state population. & 7.574 & 4.247 & 10,375 \\
\hline Nazi State & $\begin{array}{l}\text { State-Level indicator for whether the Nazi party } \\
\text { earned more than the national median percent of } \\
\text { votes in the } 1928 \text { elections }\end{array}$ & 0.518 & 0.500 & 13,146 \\
\hline GDP per capita & State-level GDP per capita & 23.916 & 5.752 & 10,375 \\
\hline
\end{tabular}


Table 3A. The Impact of Perceived Personal Economic Conditions on Attitudes towards Foreigners regarding their Rights

\begin{tabular}{|c|c|c|c|c|c|c|}
\hline & \multicolumn{2}{|c|}{$\begin{array}{c}\text { Foreigners living in Germany } \\
\text { Should... }\end{array}$} & \multirow{2}{*}{$\begin{array}{c}(3) \\
\text { Jewish people } \\
\text { living in } \\
\text { Germany } \\
\text { should not } \\
\text { have the same } \\
\text { rights as } \\
\text { Germans }\end{array}$} & \multirow{2}{*}{$\begin{array}{c}(4) \\
\text { Ethnic } \\
\text { Germans from } \\
\text { Eastern } \\
\text { Europe living } \\
\text { in Germany } \\
\text { should not } \\
\text { have the same } \\
\text { rights as } \\
\text { Germans }\end{array}$} & \multirow{2}{*}{$\begin{array}{c}(5) \\
\text { Turkish people } \\
\text { living in } \\
\text { Germany } \\
\text { should not } \\
\text { have the same } \\
\text { rights as } \\
\text { Germans }\end{array}$} & \multirow{2}{*}{$\begin{array}{c}(6) \\
\text { Italians living } \\
\text { in Germany } \\
\text { should not } \\
\text { have the same } \\
\text { rights as } \\
\text { Germans }\end{array}$} \\
\hline & $\begin{array}{c}\text {...marry } \\
\text { only people } \\
\text { of their own } \\
\text { nationality }\end{array}$ & $\begin{array}{l}\text {...not be } \\
\text { allowed to } \\
\text { take part in } \\
\text { any political } \\
\text { activity }\end{array}$ & & & & \\
\hline $\begin{array}{l}\text { Good Personal } \\
\text { Economic Conditions }\end{array}$ & $\begin{array}{l}-0.0272^{* * * *} \\
(0.0071)\end{array}$ & $\begin{array}{l}-0.0374^{* * * *} \\
(0.0069)\end{array}$ & $\begin{array}{l}-0.0507^{* * * *} \\
(0.0129)\end{array}$ & $\begin{array}{c}-0.0332^{* * * *} \\
(0.0125)\end{array}$ & $\begin{array}{l}-0.0680^{* * *} \\
(0.0140)\end{array}$ & $\begin{array}{l}-0.0287^{* * *} \\
(0.0135)\end{array}$ \\
\hline $\begin{array}{l}\text { Bad Personal } \\
\text { Economic Conditions }\end{array}$ & $\begin{array}{l}0.0242^{* *} \\
(0.0119)\end{array}$ & $\begin{array}{l}0.0459^{* * *} \\
(0.0101)\end{array}$ & $\begin{array}{l}0.0634^{* * *} \\
(0.0194)\end{array}$ & $\begin{array}{l}0.0644^{* * *} \\
(0.0243)\end{array}$ & $\begin{array}{l}0.0463^{* *} \\
(0.0215)\end{array}$ & $\begin{array}{l}0.0481^{* *} \\
(0.0238)\end{array}$ \\
\hline Age & $\begin{array}{c}0.0025^{*} \\
(0.0014)\end{array}$ & $\begin{array}{l}0.0048^{* * *} \\
(0.0014)\end{array}$ & $\begin{array}{c}0.0019 \\
(0.0020)\end{array}$ & $\begin{array}{l}0.0048^{* *} \\
(0.0023)\end{array}$ & $\begin{array}{c}0.0011 \\
(0.0024)\end{array}$ & $\begin{array}{c}0.0006 \\
(0.0022)\end{array}$ \\
\hline Age-squared & $\begin{array}{c}0.0000 \\
(0.0000)\end{array}$ & $\begin{array}{l}-0.0000 \\
(0.0000)\end{array}$ & $\begin{array}{l}-0.0000 \\
(0.0000)\end{array}$ & $\begin{array}{l}-0.0000^{*} \\
(0.0000)\end{array}$ & $\begin{array}{c}0.0000 \\
(0.0000)\end{array}$ & $\begin{array}{c}0.0000 \\
(0.0000)\end{array}$ \\
\hline Married & $\begin{array}{l}-0.0003 \\
(0.0080)\end{array}$ & $\begin{array}{l}0.0256^{* *} \\
(0.0109)\end{array}$ & $\begin{array}{c}0.0043 \\
(0.0141)\end{array}$ & $\begin{array}{l}-0.0047 \\
(0.0159)\end{array}$ & $\begin{array}{c}0.0283 \\
(0.0181)\end{array}$ & $\begin{array}{c}0.0070 \\
(0.0139)\end{array}$ \\
\hline Female & $\begin{array}{c}0.0018 \\
(0.0051)\end{array}$ & $\begin{array}{l}-0.0053 \\
(0.0070)\end{array}$ & $\begin{array}{c}-0.0313^{* * *} \\
(0.0101)\end{array}$ & $\begin{array}{c}0.0023 \\
(0.0123)\end{array}$ & $\begin{array}{l}-0.0246^{* *} \\
(0.0104)\end{array}$ & $\begin{array}{c}-0.0284^{* * *} \\
(0.0103)\end{array}$ \\
\hline Catholic & $\begin{array}{l}-0.0001 \\
(0.0094)\end{array}$ & $\begin{array}{c}0.0017 \\
(0.0126)\end{array}$ & $\begin{array}{c}0.0174 \\
(0.0160)\end{array}$ & $\begin{array}{c}0.0002 \\
(0.0156)\end{array}$ & $\begin{array}{l}0.0307^{*} \\
(0.0156)\end{array}$ & $\begin{array}{c}0.0006 \\
(0.0171)\end{array}$ \\
\hline $\begin{array}{l}\text { No Religion/ } \\
\text { Other Religion }\end{array}$ & $\begin{array}{l}-0.0150^{*} \\
(0.0080)\end{array}$ & $\begin{array}{l}-0.0220^{*} \\
(0.0112)\end{array}$ & $\begin{array}{l}-0.0334^{* *} \\
(0.0144)\end{array}$ & $\begin{array}{l}-0.0254 \\
(0.0170)\end{array}$ & $\begin{array}{l}-0.0413^{* *} \\
(0.0194)\end{array}$ & $\begin{array}{l}-0.0360^{* *} \\
(0.0176)\end{array}$ \\
\hline $\begin{array}{l}\text { Education: } \\
\text { Vocational }\end{array}$ & $\begin{array}{l}-0.0806^{* * *} \\
(0.0099)\end{array}$ & $\begin{array}{l}-0.0127 \\
(0.0121)\end{array}$ & $\begin{array}{l}-0.0233 \\
(0.0151)\end{array}$ & $\begin{array}{c}0.0013 \\
(0.0204)\end{array}$ & $\begin{array}{l}-0.0283 \\
(0.0178)\end{array}$ & $\begin{array}{l}-0.0152 \\
(0.0163)\end{array}$ \\
\hline $\begin{array}{l}\text { Education: } \\
\text { Adv. Technical }\end{array}$ & $\begin{array}{l}-0.1372^{* * *} \\
(0.0118)\end{array}$ & $\begin{array}{c}-0.0729^{* * *} \\
(0.0161)\end{array}$ & $\begin{array}{c}-0.0496^{* * *} \\
(0.0182)\end{array}$ & $\begin{array}{l}-0.0119 \\
(0.0230)\end{array}$ & $\begin{array}{l}-0.0357 \\
(0.0221)\end{array}$ & $\begin{array}{l}-0.0141 \\
(0.0233)\end{array}$ \\
\hline $\begin{array}{l}\text { Education: } \\
\text { College }\end{array}$ & $\begin{array}{l}-0.1782^{* * *} \\
(0.0132)\end{array}$ & $\begin{array}{l}-0.1640^{* * *} \\
(0.0139)\end{array}$ & $\begin{array}{l}-0.1099^{* * *} \\
(0.0213)\end{array}$ & $\begin{array}{l}-0.0897^{* * * *} \\
(0.0242)\end{array}$ & $\begin{array}{l}-0.1013^{* * *} \\
(0.0229)\end{array}$ & $\begin{array}{c}-0.0593^{* * *} \\
(0.0225)\end{array}$ \\
\hline $\begin{array}{l}\text { Currently } \\
\text { Working }\end{array}$ & $\begin{array}{l}-0.0180^{* *} \\
(0.0082)\end{array}$ & $\begin{array}{c}-0.0212^{* *} \\
(0.0096)\end{array}$ & $\begin{array}{c}0.0144 \\
(0.0148)\end{array}$ & $\begin{array}{c}0.0065 \\
(0.0154)\end{array}$ & $\begin{array}{l}-0.0111 \\
(0.0177)\end{array}$ & $\begin{array}{c}0.0039 \\
(0.0152)\end{array}$ \\
\hline $\begin{array}{l}\text { City Size: } \\
50,000-99,999\end{array}$ & $\begin{array}{l}-0.0059 \\
(0.0128)\end{array}$ & $\begin{array}{c}0.0055 \\
(0.0154)\end{array}$ & $\begin{array}{l}-0.0446^{*} \\
(0.0236)\end{array}$ & $\begin{array}{l}-0.0601^{* *} \\
(0.0255)\end{array}$ & $\begin{array}{l}-0.0497^{*} \\
(0.0257)\end{array}$ & $\begin{array}{l}-0.0456^{*} \\
(0.0266)\end{array}$ \\
\hline $\begin{array}{l}\text { City Size: } \\
100,000-499,999\end{array}$ & $\begin{array}{l}-0.0296^{* *} \\
(0.0115)\end{array}$ & $\begin{array}{l}-0.0273^{* *} \\
(0.0126)\end{array}$ & $\begin{array}{l}-0.0188 \\
(0.0263)\end{array}$ & $\begin{array}{c}0.0208 \\
(0.0286)\end{array}$ & $\begin{array}{l}-0.0313 \\
(0.0286)\end{array}$ & $\begin{array}{l}-0.0255 \\
(0.0244)\end{array}$ \\
\hline $\begin{array}{l}\text { City Size: } \\
500,000+\end{array}$ & $\begin{array}{l}-0.0344^{* *} \\
(0.0134)\end{array}$ & $\begin{array}{l}-0.0137 \\
(0.0158)\end{array}$ & $\begin{array}{l}-0.0259 \\
(0.0252)\end{array}$ & $\begin{array}{l}-0.0098 \\
(0.0247)\end{array}$ & $\begin{array}{c}-0.0464^{* * *} \\
(0.0202)\end{array}$ & $\begin{array}{l}-0.0322 \\
(0.0232)\end{array}$ \\
\hline Inner City & $\begin{array}{c}0.0015 \\
(0.0115)\end{array}$ & $\begin{array}{l}-0.0101 \\
(0.0144)\end{array}$ & $\begin{array}{l}-0.0440^{* *} \\
(0.0217)\end{array}$ & $\begin{array}{l}-0.0159 \\
(0.0205)\end{array}$ & $\begin{array}{l}-0.0103 \\
(0.0221)\end{array}$ & $\begin{array}{l}-0.0280^{*} \\
(0.0142)\end{array}$ \\
\hline Observations & 13,146 & 13,102 & 5,905 & 6,100 & 6,090 & 6,096 \\
\hline
\end{tabular}

Note: Standard errors clustered at the age group-state level in parentheses, ${ }^{*} p<0.1,{ }^{* *} p<0.05,{ }^{* * *} p<0.01$. All regressions use sampling weights, and also include state dummies and year dummies. 
Table 3B: The Impact of Perceived Personal Economic Conditions on Attitudes towards Foreigners regarding Marriage and Family

\begin{tabular}{|c|c|c|c|c|c|c|c|c|}
\hline & \multirow{2}{*}{\multicolumn{4}{|c|}{$\begin{array}{l}(1) \quad(2) \quad(3) \\
\text { It would be unpleasant to have neighbor who } \\
\text { is }\end{array}$}} & \multirow{2}{*}{\multicolumn{4}{|c|}{$\begin{array}{c}(5) \quad(6) \\
\text { It would be unpleasant if a ... person married } \\
\text { into the family }\end{array}$}} \\
\hline & & & & & & & & \\
\hline & Jewish & $\begin{array}{c}\text { Ethnic } \\
\text { German } \\
\text { from } \\
\text { Eastern } \\
\text { Europe }\end{array}$ & Turkish & Italian & Jewish & $\begin{array}{c}\text { Ethnic } \\
\text { German } \\
\text { from } \\
\text { Eastern } \\
\text { Europe }\end{array}$ & Turkish & Italian \\
\hline $\begin{array}{l}\text { Good Personal } \\
\text { Economic Conditions }\end{array}$ & $\begin{array}{l}-0.0339^{\text {and }} \\
(0.0088)\end{array}$ & $\begin{array}{l}-0.0543^{\text {*.;.7. }} \\
(0.0139)\end{array}$ & $\begin{array}{l}-0.0500 \\
(0.0140)\end{array}$ & $\begin{array}{l}-0.0170 \\
(0.0077)\end{array}$ & $\begin{array}{l}-0.0230^{*} \\
(0.0131)\end{array}$ & $\begin{array}{l}-0.0417 \\
(0.0126)\end{array}$ & $\begin{array}{l}-0.0254^{*} \\
(0.0142)\end{array}$ & $\begin{array}{l}-0.0281 \\
(0.0101)\end{array}$ \\
\hline $\begin{array}{l}\text { Bad Personal } \\
\text { Economic Conditions }\end{array}$ & $\begin{array}{l}0.0258^{*} \\
(0.0137)\end{array}$ & $\begin{array}{l}-0.0125 \\
(0.0196)\end{array}$ & $\begin{array}{c}0.0183 \\
(0.0234)\end{array}$ & $\begin{array}{l}-0.0022 \\
(0.0107)\end{array}$ & $\begin{array}{c}0.0183 \\
(0.0189)\end{array}$ & $\begin{array}{c}0.0213 \\
(0.0188)\end{array}$ & $\begin{array}{l}-0.0119 \\
(0.0213)\end{array}$ & $\begin{array}{l}0.0264^{*} \\
(0.0152)\end{array}$ \\
\hline Age & $\begin{array}{c}0.0010 \\
(0.0017)\end{array}$ & $\begin{array}{l}0.0043^{* *} \\
(0.0019)\end{array}$ & $\begin{array}{l}-0.0020 \\
(0.0025)\end{array}$ & $\begin{array}{c}0.0018 \\
(0.0014)\end{array}$ & $\begin{array}{l}0.0080^{* * *} \\
(0.0023)\end{array}$ & $\begin{array}{l}0.0068^{* * *} \\
(0.0021)\end{array}$ & $\begin{array}{l}0.0048^{*} \\
(0.0028)\end{array}$ & $\begin{array}{c}0.0021 \\
(0.0017)\end{array}$ \\
\hline Age-squared & $\begin{array}{c}0.0000 \\
(0.0000)\end{array}$ & $\begin{array}{l}-0.0000^{*} \\
(0.0000)\end{array}$ & $\begin{array}{l}0.0001^{* *} \\
(0.0000)\end{array}$ & $\begin{array}{l}-0.0000 \\
(0.0000)\end{array}$ & $\begin{array}{l}-0.0000^{*} \\
(0.0000)\end{array}$ & $\begin{array}{l}-0.0000^{*} \\
(0.0000)\end{array}$ & $\begin{array}{c}0.0000 \\
(0.0000)\end{array}$ & $\begin{array}{c}0.0000 \\
(0.0000)\end{array}$ \\
\hline Married & $\begin{array}{c}0.0057 \\
(0.0116)\end{array}$ & $\begin{array}{l}-0.0248^{* *} \\
(0.0120)\end{array}$ & $\begin{array}{c}0.0170 \\
(0.0157)\end{array}$ & $\begin{array}{l}-0.0085 \\
(0.0072)\end{array}$ & $\begin{array}{l}0.0218^{*} \\
(0.0128)\end{array}$ & $\begin{array}{c}0.0138 \\
(0.0151)\end{array}$ & $\begin{array}{c}0.0438^{* * *} \\
(0.0145)\end{array}$ & $\begin{array}{l}0.0245^{* *} \\
(0.0122)\end{array}$ \\
\hline Female & $\begin{array}{l}-0.0256^{* * *} \\
(0.0078)\end{array}$ & $\begin{array}{l}-0.0246^{* *} \\
(0.0106)\end{array}$ & $\begin{array}{l}-0.0218^{*} \\
(0.0121)\end{array}$ & $\begin{array}{l}-0.0176^{* * *} \\
(0.0066)\end{array}$ & $\begin{array}{c}-0.0301^{* * *} \\
(0.0105)\end{array}$ & $\begin{array}{l}-0.0221 \\
(0.0141)\end{array}$ & $\begin{array}{c}-0.0372^{* * *} \\
(0.0121)\end{array}$ & $\begin{array}{c}-0.0409^{* * *} \\
(0.0092)\end{array}$ \\
\hline Catholic & $\begin{array}{c}0.0038 \\
(0.0146)\end{array}$ & $\begin{array}{c}0.0028 \\
(0.0151)\end{array}$ & $\begin{array}{l}0.0357^{*} \\
(0.0208)\end{array}$ & $\begin{array}{c}0.0113 \\
(0.0086)\end{array}$ & $\begin{array}{c}0.0296 \\
(0.0243)\end{array}$ & $\begin{array}{c}0.0037 \\
(0.0180)\end{array}$ & $\begin{array}{l}0.0357^{*} \\
(0.0191)\end{array}$ & $\begin{array}{c}0.0172 \\
(0.0145)\end{array}$ \\
\hline $\begin{array}{l}\text { No Religion/ } \\
\text { Other Religion }\end{array}$ & $\begin{array}{c}0.0067 \\
(0.0121)\end{array}$ & $\begin{array}{c}0.0082 \\
(0.0139)\end{array}$ & $\begin{array}{l}-0.0106 \\
(0.0162)\end{array}$ & $\begin{array}{c}0.0028 \\
(0.0083)\end{array}$ & $\begin{array}{l}-0.0124 \\
(0.0162)\end{array}$ & $\begin{array}{l}-0.0174 \\
(0.0182)\end{array}$ & $\begin{array}{c}-0.0714^{* * *} \\
(0.0190)\end{array}$ & $\begin{array}{l}-0.0162 \\
(0.0118)\end{array}$ \\
\hline $\begin{array}{l}\text { Education: } \\
\text { Vocational }\end{array}$ & $\begin{array}{l}-0.0281^{* *} \\
(0.0134)\end{array}$ & $\begin{array}{c}0.0003 \\
(0.0147)\end{array}$ & $\begin{array}{l}-0.0425^{* *} \\
(0.0206)\end{array}$ & $\begin{array}{c}-0.0390^{* * *} \\
(0.0130)\end{array}$ & $\begin{array}{c}-0.0686^{* * * *} \\
(0.0167)\end{array}$ & $\begin{array}{l}-0.0028 \\
(0.0196)\end{array}$ & $\begin{array}{l}-0.0371^{*} \\
(0.0198)\end{array}$ & $\begin{array}{c}-0.0615^{* * *} \\
(0.0168)\end{array}$ \\
\hline $\begin{array}{l}\text { Education: } \\
\text { Adv. Technical }\end{array}$ & $\begin{array}{l}-0.0483^{* *} \\
(0.0189)\end{array}$ & $\begin{array}{l}-0.0300 \\
(0.0184)\end{array}$ & $\begin{array}{c}-0.0803^{* * *} \\
(0.0219)\end{array}$ & $\begin{array}{c}-0.0514^{* * *} \\
(0.0121)\end{array}$ & $\begin{array}{c}-0.1202^{* * *} \\
(0.0236)\end{array}$ & $\begin{array}{l}-0.0548^{* *} \\
(0.0235)\end{array}$ & $\begin{array}{c}-0.0759^{* * * *} \\
(0.0227)\end{array}$ & $\begin{array}{c}-0.0996^{* * *} \\
(0.0182)\end{array}$ \\
\hline $\begin{array}{l}\text { Education: } \\
\text { College }\end{array}$ & $\begin{array}{c}-0.0818^{* * *} \\
(0.0167)\end{array}$ & $\begin{array}{l}-0.0496^{* *} \\
(0.0231)\end{array}$ & $\begin{array}{c}-0.1350^{* * *} \\
(0.0272)\end{array}$ & $\begin{array}{c}-0.0541^{\text {*** }} \\
(0.0147)\end{array}$ & $\begin{array}{c}-0.1701^{* * *} \\
(0.0206)\end{array}$ & $\begin{array}{c}-0.1298^{* * *} \\
(0.0236)\end{array}$ & $\begin{array}{c}-0.1653^{* * *} \\
(0.0247)\end{array}$ & $\begin{array}{c}-0.1429^{* * *} \\
(0.0214)\end{array}$ \\
\hline $\begin{array}{l}\text { Currently } \\
\text { Working }\end{array}$ & $\begin{array}{l}-0.0105 \\
(0.0100)\end{array}$ & $\begin{array}{c}0.0061 \\
(0.0158)\end{array}$ & $\begin{array}{l}-0.0075 \\
(0.0156)\end{array}$ & $\begin{array}{l}-0.0027 \\
(0.0089)\end{array}$ & $\begin{array}{c}0.0058 \\
(0.0155)\end{array}$ & $\begin{array}{c}0.0022 \\
(0.0134)\end{array}$ & $\begin{array}{c}0.0091 \\
(0.0166)\end{array}$ & $\begin{array}{l}-0.0096 \\
(0.0092)\end{array}$ \\
\hline $\begin{array}{l}\text { City Size: } \\
50,000-99,999\end{array}$ & $\begin{array}{l}-0.0113 \\
(0.0156)\end{array}$ & $\begin{array}{l}-0.0410^{*} \\
(0.0220)\end{array}$ & $\begin{array}{l}-0.0095 \\
(0.0244)\end{array}$ & $\begin{array}{l}-0.0207 \\
(0.0170)\end{array}$ & $\begin{array}{l}-0.0197 \\
(0.0201)\end{array}$ & $\begin{array}{l}-0.0382 \\
(0.0316)\end{array}$ & $\begin{array}{l}-0.0154 \\
(0.0229)\end{array}$ & $\begin{array}{l}-0.0108 \\
(0.0152)\end{array}$ \\
\hline $\begin{array}{l}\text { City Size: } \\
\text { 100,000-499,999 }\end{array}$ & $\begin{array}{l}-0.0087 \\
(0.0143)\end{array}$ & $\begin{array}{c}0.0046 \\
(0.0237)\end{array}$ & $\begin{array}{l}-0.0582^{* *} \\
(0.0224)\end{array}$ & $\begin{array}{l}-0.0225^{* *} \\
(0.0101)\end{array}$ & $\begin{array}{l}-0.0064 \\
(0.0197)\end{array}$ & $\begin{array}{c}0.0027 \\
(0.0274)\end{array}$ & $\begin{array}{l}-0.0427^{* *} \\
(0.0189)\end{array}$ & $\begin{array}{l}-0.0061 \\
(0.0150)\end{array}$ \\
\hline $\begin{array}{l}\text { City Size: } \\
500,000+\end{array}$ & $\begin{array}{l}-0.0028 \\
(0.0147)\end{array}$ & $\begin{array}{l}-0.0053 \\
(0.0216)\end{array}$ & $\begin{array}{l}-0.0395^{*} \\
(0.0214)\end{array}$ & $\begin{array}{l}-0.0104 \\
(0.0111)\end{array}$ & $\begin{array}{l}-0.0396^{* *} \\
(0.0190)\end{array}$ & $\begin{array}{l}-0.0332 \\
(0.0249)\end{array}$ & $\begin{array}{c}-0.0511^{* * *} \\
(0.0183)\end{array}$ & $\begin{array}{l}-0.0378^{* *} \\
(0.0163)\end{array}$ \\
\hline Inner City & $\begin{array}{l}-0.0210 \\
(0.0160) \\
\end{array}$ & $\begin{array}{c}0.0054 \\
(0.0190)\end{array}$ & $\begin{array}{c}0.0088 \\
(0.0153)\end{array}$ & $\begin{array}{c}0.0048 \\
(0.0075)\end{array}$ & $\begin{array}{l}-0.0316^{*} \\
(0.0180)\end{array}$ & $\begin{array}{l}-0.0038 \\
(0.0213)\end{array}$ & $\begin{array}{l}-0.0080 \\
(0.0204)\end{array}$ & $\begin{array}{l}-0.0072 \\
(0.0122)\end{array}$ \\
\hline Observations & 6,024 & 6,134 & 6,141 & 6,141 & 5,985 & 6,107 & 6,111 & 6,120 \\
\hline
\end{tabular}


Table 4A. The Impact of Perceived National Economic Conditions on Attitudes towards Foreigners regarding their Rights

\begin{tabular}{|c|c|c|c|c|c|c|}
\hline & \multicolumn{2}{|c|}{$\begin{array}{c}\text { Foreigners living in Germany } \\
\text { Should... }\end{array}$} & \multirow{2}{*}{$\begin{array}{c}\text { (3) } \\
\text { Jewish people } \\
\text { living in } \\
\text { Germany } \\
\text { should not } \\
\text { have the same } \\
\text { rights as } \\
\text { Germans }\end{array}$} & \multirow{2}{*}{$\begin{array}{c}(4) \\
\text { Ethnic } \\
\text { Germans from } \\
\text { Eastern } \\
\text { Europe living } \\
\text { in Germany } \\
\text { should not } \\
\text { have the same } \\
\text { rights as } \\
\text { Germans }\end{array}$} & \multirow{2}{*}{$\begin{array}{c}\text { (5) } \\
\text { Turkish people } \\
\text { living in } \\
\text { Germany } \\
\text { should not } \\
\text { have the same } \\
\text { rights as } \\
\text { Germans }\end{array}$} & \multirow{2}{*}{$\begin{array}{c}(6) \\
\text { Italians living } \\
\text { in Germany } \\
\text { should not } \\
\text { have the same } \\
\text { rights as } \\
\text { Germans }\end{array}$} \\
\hline & $\begin{array}{l}\text {...marry only } \\
\text { people of } \\
\text { their own } \\
\text { nationality }\end{array}$ & $\begin{array}{l}\text {...not be } \\
\text { allowed to } \\
\text { take part in } \\
\text { any political } \\
\text { activity }\end{array}$ & & & & \\
\hline $\begin{array}{l}\text { Good National } \\
\text { Economic Conditions }\end{array}$ & $\begin{array}{l}-0.0107 \\
(0.0079)\end{array}$ & $\begin{array}{l}-0.0201^{* *} \\
(0.0095)\end{array}$ & $\begin{array}{c}0.0231 \\
(0.0176)\end{array}$ & $\begin{array}{l}-0.0208 \\
(0.0184)\end{array}$ & $\begin{array}{c}0.0137 \\
(0.0211)\end{array}$ & $\begin{array}{c}0.0081 \\
(0.0171)\end{array}$ \\
\hline $\begin{array}{l}\text { Bad National } \\
\text { Economic Conditions }\end{array}$ & $\begin{array}{l}0.0361^{* * *} \\
(0.0069)\end{array}$ & $\begin{array}{l}0.0628^{* * *} \\
(0.0093)\end{array}$ & $\begin{array}{l}0.0661^{\text {*** }} \\
(0.0113)\end{array}$ & $\begin{array}{l}0.0782^{* * *} \\
(0.0121)\end{array}$ & $\begin{array}{l}0.0804^{* * *} \\
(0.0113)\end{array}$ & $\begin{array}{l}0.0590^{* * *} \\
(0.0126)\end{array}$ \\
\hline Age & $\begin{array}{l}0.0030^{* *} \\
(0.0014)\end{array}$ & $\begin{array}{l}0.0054^{* * *} \\
(0.0014)\end{array}$ & $\begin{array}{c}0.0028 \\
(0.0020)\end{array}$ & $\begin{array}{l}0.0054^{* *} \\
(0.0023)\end{array}$ & $\begin{array}{c}0.0024 \\
(0.0023)\end{array}$ & $\begin{array}{c}0.0013 \\
(0.0021)\end{array}$ \\
\hline Age-squared & $\begin{array}{c}0.0000 \\
(0.0000)\end{array}$ & $\begin{array}{l}-0.0000 \\
(0.0000)\end{array}$ & $\begin{array}{l}-0.0000 \\
(0.0000)\end{array}$ & $\begin{array}{l}-0.0000^{* *} \\
(0.0000)\end{array}$ & $\begin{array}{c}0.0000 \\
(0.0000)\end{array}$ & $\begin{array}{l}-0.0000 \\
(0.0000)\end{array}$ \\
\hline Married & $\begin{array}{l}-0.0058 \\
(0.0079)\end{array}$ & $\begin{array}{c}0.0198^{*} \\
(0.0106)\end{array}$ & $\begin{array}{l}-0.0078 \\
(0.0139)\end{array}$ & $\begin{array}{l}-0.0136 \\
(0.0159)\end{array}$ & $\begin{array}{c}0.0156 \\
(0.0179)\end{array}$ & $\begin{array}{l}-0.0000 \\
(0.0136)\end{array}$ \\
\hline Female & $\begin{array}{l}-0.0011 \\
(0.0053)\end{array}$ & $\begin{array}{l}-0.0102 \\
(0.0071)\end{array}$ & $\begin{array}{c}-0.0319^{* * *} \\
(0.0100)\end{array}$ & $\begin{array}{l}-0.0006 \\
(0.0124)\end{array}$ & $\begin{array}{l}-0.0257^{* *} \\
(0.0104)\end{array}$ & $\begin{array}{c}-0.0302^{* * *} \\
(0.0106)\end{array}$ \\
\hline Catholic & $\begin{array}{c}0.0001 \\
(0.0094)\end{array}$ & $\begin{array}{c}0.0002 \\
(0.0123)\end{array}$ & $\begin{array}{c}0.0158 \\
(0.0165)\end{array}$ & $\begin{array}{l}-0.0008 \\
(0.0159)\end{array}$ & $\begin{array}{c}0.0284^{*} \\
(0.0163)\end{array}$ & $\begin{array}{c}0.0002 \\
(0.0171)\end{array}$ \\
\hline $\begin{array}{l}\text { No Religion/ } \\
\text { Other Religion }\end{array}$ & $\begin{array}{l}-0.0136^{*} \\
(0.0079)\end{array}$ & $\begin{array}{l}-0.0225^{* *} \\
(0.0112)\end{array}$ & $\begin{array}{l}-0.0325^{* *} \\
(0.0146)\end{array}$ & $\begin{array}{l}-0.0241 \\
(0.0170)\end{array}$ & $\begin{array}{l}-0.0432^{* *} \\
(0.0205)\end{array}$ & $\begin{array}{l}-0.0371^{* *} \\
(0.0183)\end{array}$ \\
\hline $\begin{array}{l}\text { Education: } \\
\text { Vocational }\end{array}$ & $\begin{array}{c}-0.0820^{* * *} \\
(0.0100)\end{array}$ & $\begin{array}{l}-0.0151 \\
(0.0126)\end{array}$ & $\begin{array}{l}-0.0295^{* *} \\
(0.0148)\end{array}$ & $\begin{array}{l}-0.0040 \\
(0.0196)\end{array}$ & $\begin{array}{l}-0.0334^{*} \\
(0.0174)\end{array}$ & $\begin{array}{l}-0.0207 \\
(0.0163)\end{array}$ \\
\hline $\begin{array}{l}\text { Education: } \\
\text { Adv. Technical }\end{array}$ & $\begin{array}{c}-0.1406^{* * *} \\
(0.0120)\end{array}$ & $\begin{array}{c}-0.0765^{* * *} \\
(0.0165)\end{array}$ & $\begin{array}{l}-0.0602^{* * *} \\
(0.0179)\end{array}$ & $\begin{array}{l}-0.0190 \\
(0.0207)\end{array}$ & $\begin{array}{l}-0.0481^{* *} \\
(0.0217)\end{array}$ & $\begin{array}{l}-0.0222 \\
(0.0236)\end{array}$ \\
\hline $\begin{array}{l}\text { Education: } \\
\text { College }\end{array}$ & $\begin{array}{c}-0.1817^{* * *} \\
(0.0132)\end{array}$ & $\begin{array}{l}-0.1679^{* * *} \\
(0.0142)\end{array}$ & $\begin{array}{l}-0.1243^{* * *} \\
(0.0217)\end{array}$ & $\begin{array}{c}-0.0935^{\text {**** }} \\
(0.0225)\end{array}$ & $\begin{array}{l}-0.1146^{* * *} \\
(0.0220)\end{array}$ & $\begin{array}{c}-0.0665^{* * *} \\
(0.0227)\end{array}$ \\
\hline $\begin{array}{l}\text { Currently } \\
\text { Working }\end{array}$ & $\begin{array}{c}-0.0215^{* * *} \\
(0.0082)\end{array}$ & $\begin{array}{c}-0.0265^{* * *} \\
(0.0092)\end{array}$ & $\begin{array}{c}0.0081 \\
(0.0150)\end{array}$ & $\begin{array}{l}-0.0004 \\
(0.0146)\end{array}$ & $\begin{array}{l}-0.0173 \\
(0.0173)\end{array}$ & $\begin{array}{l}-0.0020 \\
(0.0149)\end{array}$ \\
\hline $\begin{array}{l}\text { City Size: } \\
\text { 50,000-99,999 }\end{array}$ & $\begin{array}{l}-0.0031 \\
(0.0126)\end{array}$ & $\begin{array}{c}0.0017 \\
(0.0154)\end{array}$ & $\begin{array}{l}-0.0429^{*} \\
(0.0236)\end{array}$ & $\begin{array}{l}-0.0561^{* *} \\
(0.0254)\end{array}$ & $\begin{array}{l}-0.0474^{*} \\
(0.0254)\end{array}$ & $\begin{array}{l}-0.0409 \\
(0.0269)\end{array}$ \\
\hline $\begin{array}{l}\text { City Size: } \\
100,000-499,999\end{array}$ & $\begin{array}{l}-0.0277^{* *} \\
(0.0114)\end{array}$ & $\begin{array}{l}-0.0283^{* *} \\
(0.0121)\end{array}$ & $\begin{array}{l}-0.0162 \\
(0.0265)\end{array}$ & $\begin{array}{c}0.0241 \\
(0.0284)\end{array}$ & $\begin{array}{l}-0.0260 \\
(0.0283)\end{array}$ & $\begin{array}{l}-0.0245 \\
(0.0243)\end{array}$ \\
\hline $\begin{array}{l}\text { City Size: } \\
500,000+\end{array}$ & $\begin{array}{l}-0.0345^{* *} \\
(0.0133)\end{array}$ & $\begin{array}{l}-0.0167 \\
(0.0156)\end{array}$ & $\begin{array}{l}-0.0282 \\
(0.0256)\end{array}$ & $\begin{array}{l}-0.0093 \\
(0.0248)\end{array}$ & $\begin{array}{l}-0.0484^{* *} \\
(0.0202)\end{array}$ & $\begin{array}{l}-0.0346 \\
(0.0226)\end{array}$ \\
\hline Inner City & $\begin{array}{c}0.0007 \\
(0.0113)\end{array}$ & $\begin{array}{l}-0.0082 \\
(0.0141)\end{array}$ & $\begin{array}{l}-0.0446^{* *} \\
(0.0220)\end{array}$ & $\begin{array}{l}-0.0171 \\
(0.0204)\end{array}$ & $\begin{array}{l}-0.0105 \\
(0.0219)\end{array}$ & $\begin{array}{l}-0.0274^{*} \\
(0.0142)\end{array}$ \\
\hline Observations & 13,110 & 13,071 & 5,894 & 6,089 & 6,079 & 6,084 \\
\hline
\end{tabular}

Note: Standard errors clustered at the age group-state level in parentheses, ${ }^{*} p<0.1,{ }^{* * *} p<0.05,{ }^{* * * *} p<0.01$. All regressions use sampling weights, and also include state dummies and year dummies. 
Table 4B: The Impact of Perceived National Economic Conditions on Attitudes towards

Foreigners regarding Marriage and Family

\begin{tabular}{|c|c|c|c|c|c|c|c|c|}
\hline & \multirow{2}{*}{\multicolumn{4}{|c|}{$\begin{array}{l}\text { It would be unpleasant to have neighbor who } \\
\text { is }\end{array}$}} & \multirow{2}{*}{\multicolumn{4}{|c|}{$\begin{array}{l}\text { It would be unpleasant if a ... person married } \\
\text { into the family }\end{array}$}} \\
\hline & & & & & & & & \\
\hline & Jewish & $\begin{array}{c}\text { Ethnic } \\
\text { German } \\
\text { from } \\
\text { Eastern } \\
\text { Europe } \\
\end{array}$ & Turkish & Italian & Jewish & $\begin{array}{c}\text { Ethnic } \\
\text { German } \\
\text { from } \\
\text { Eastern } \\
\text { Europe } \\
\end{array}$ & Turkish & Italian \\
\hline $\begin{array}{l}\text { Good National } \\
\text { Economic Conditions }\end{array}$ & $\begin{array}{c}0.0054 \\
(0.0150)\end{array}$ & $\begin{array}{l}-0.0247^{\prime \prime} \\
(0.0147)\end{array}$ & $\begin{array}{l}-0.0430 \\
(0.0221)\end{array}$ & $\begin{array}{l}-0.0069 \\
(0.0099)\end{array}$ & $\begin{array}{l}0.0095 \\
(0.0195)\end{array}$ & $\begin{array}{l}-0.0272 \\
(0.0176)\end{array}$ & $\begin{array}{l}-0.0412 \\
(0.0177)\end{array}$ & $\begin{array}{l}-0.0122 \\
(0.0141)\end{array}$ \\
\hline $\begin{array}{l}\text { Bad National } \\
\text { Economic Conditions }\end{array}$ & $\begin{array}{l}0.0473^{* * *} \\
(0.0097)\end{array}$ & $\begin{array}{l}0.0565^{* * *} \\
(0.0110)\end{array}$ & $\begin{array}{l}0.0522^{* * *} \\
(0.0124)\end{array}$ & $\begin{array}{l}0.0128^{*} \\
(0.0069)\end{array}$ & $\begin{array}{l}0.0455^{* * *} \\
(0.0138)\end{array}$ & $\begin{array}{l}0.0635^{* * *} \\
(0.0117)\end{array}$ & $\begin{array}{l}0.0516^{* * *} \\
(0.0142)\end{array}$ & $\begin{array}{l}0.0264^{* *} \\
(0.0102)\end{array}$ \\
\hline Age & $\begin{array}{c}0.0016 \\
(0.0018)\end{array}$ & $\begin{array}{l}0.0046^{* * *} \\
(0.0017)\end{array}$ & $\begin{array}{l}-0.0011 \\
(0.0025)\end{array}$ & $\begin{array}{c}0.0017 \\
(0.0014)\end{array}$ & $\begin{array}{l}0.0085^{* * *} \\
(0.0022)\end{array}$ & $\begin{array}{l}0.0073^{* * *} \\
(0.0021)\end{array}$ & $\begin{array}{l}0.0050^{*} \\
(0.0028)\end{array}$ & $\begin{array}{l}0.0026^{*} \\
(0.0016)\end{array}$ \\
\hline Age-squared & $\begin{array}{l}-0.0000 \\
(0.0000)\end{array}$ & $\begin{array}{l}-0.0000^{* *} \\
(0.0000)\end{array}$ & $\begin{array}{l}0.0000^{*} \\
(0.0000)\end{array}$ & $\begin{array}{l}-0.0000 \\
(0.0000)\end{array}$ & $\begin{array}{l}-0.0000^{* *} \\
(0.0000)\end{array}$ & $\begin{array}{l}-0.0000^{* *} \\
(0.0000)\end{array}$ & $\begin{array}{c}0.0000 \\
(0.0000)\end{array}$ & $\begin{array}{c}0.0000 \\
(0.0000)\end{array}$ \\
\hline Married & $\begin{array}{l}-0.0009 \\
(0.0114)\end{array}$ & $\begin{array}{l}-0.0274^{* *} \\
(0.0120)\end{array}$ & $\begin{array}{c}0.0089 \\
(0.0151)\end{array}$ & $\begin{array}{l}-0.0093 \\
(0.0071)\end{array}$ & $\begin{array}{c}0.0167 \\
(0.0121)\end{array}$ & $\begin{array}{c}0.0092 \\
(0.0142)\end{array}$ & $\begin{array}{l}0.0417^{\text {*** }} \\
(0.0140)\end{array}$ & $\begin{array}{l}0.0192^{*} \\
(0.0115)\end{array}$ \\
\hline Female & $\begin{array}{c}-0.0270^{* * *} \\
(0.0080)\end{array}$ & $\begin{array}{l}-0.0270^{* *} \\
(0.0108)\end{array}$ & $\begin{array}{l}-0.0240^{* *} \\
(0.0119)\end{array}$ & $\begin{array}{c}-0.0176^{* * *} \\
(0.0067)\end{array}$ & $\begin{array}{c}-0.0302^{* * *} \\
(0.0107)\end{array}$ & $\begin{array}{l}-0.0252^{*} \\
(0.0140)\end{array}$ & $\begin{array}{c}-0.0383^{* * *} \\
(0.0121)\end{array}$ & $\begin{array}{c}-0.0413^{* * *} \\
(0.0094)\end{array}$ \\
\hline Catholic & $\begin{array}{c}0.0027 \\
(0.0148)\end{array}$ & $\begin{array}{c}0.0039 \\
(0.0154)\end{array}$ & $\begin{array}{l}0.0361^{*} \\
(0.0210)\end{array}$ & $\begin{array}{c}0.0117 \\
(0.0086)\end{array}$ & $\begin{array}{c}0.0272 \\
(0.0239)\end{array}$ & $\begin{array}{c}0.0052 \\
(0.0176)\end{array}$ & $\begin{array}{c}0.0357^{*} \\
(0.0190)\end{array}$ & $\begin{array}{c}0.0171 \\
(0.0143)\end{array}$ \\
\hline $\begin{array}{l}\text { No Religion/ } \\
\text { Other Religion }\end{array}$ & $\begin{array}{c}0.0064 \\
(0.0123)\end{array}$ & $\begin{array}{c}0.0093 \\
(0.0140)\end{array}$ & $\begin{array}{l}-0.0105 \\
(0.0166)\end{array}$ & $\begin{array}{c}0.0028 \\
(0.0082)\end{array}$ & $\begin{array}{l}-0.0126 \\
(0.0164)\end{array}$ & $\begin{array}{l}-0.0156 \\
(0.0181)\end{array}$ & $\begin{array}{c}-0.0710^{\text {**** }} \\
(0.0190)\end{array}$ & $\begin{array}{l}-0.0163 \\
(0.0116)\end{array}$ \\
\hline $\begin{array}{l}\text { Education: } \\
\text { Vocational }\end{array}$ & $\begin{array}{c}-0.0304^{* *} \\
(0.0133)\end{array}$ & $\begin{array}{l}-0.0014 \\
(0.0148)\end{array}$ & $\begin{array}{l}-0.0457^{* *} \\
(0.0207)\end{array}$ & $\begin{array}{c}-0.0403^{* * *} \\
(0.0132)\end{array}$ & $\begin{array}{c}-0.0698^{* * *} \\
(0.0170)\end{array}$ & $\begin{array}{l}-0.0057 \\
(0.0202)\end{array}$ & $\begin{array}{l}-0.0386^{*} \\
(0.0200)\end{array}$ & $\begin{array}{c}-0.0649^{* * *} \\
(0.0168)\end{array}$ \\
\hline $\begin{array}{l}\text { Education: } \\
\text { Adv. Technical }\end{array}$ & $\begin{array}{c}-0.0535^{* * *} \\
(0.0192)\end{array}$ & $\begin{array}{l}-0.0346^{*} \\
(0.0181)\end{array}$ & $\begin{array}{c}-0.0905^{* * * *} \\
(0.0228)\end{array}$ & $\begin{array}{c}-0.0539^{* * *} \\
(0.0126)\end{array}$ & $\begin{array}{c}-0.1241^{* * *} \\
(0.0242)\end{array}$ & $\begin{array}{l}-0.0608^{* *} \\
(0.0248)\end{array}$ & $\begin{array}{c}-0.0818^{* * * *} \\
(0.0226)\end{array}$ & $\begin{array}{c}-0.1088^{* * *} \\
(0.0188)\end{array}$ \\
\hline $\begin{array}{l}\text { Education: } \\
\text { College }\end{array}$ & $\begin{array}{c}-0.0870^{* * * *} \\
(0.0167)\end{array}$ & $\begin{array}{l}-0.0513^{* *} \\
(0.0233)\end{array}$ & $\begin{array}{c}-0.1396^{* * * *} \\
(0.0275)\end{array}$ & $\begin{array}{c}-0.0564^{* * *} \\
(0.0150)\end{array}$ & $\begin{array}{c}-0.1716^{* * *} \\
(0.0222)\end{array}$ & $\begin{array}{c}-0.1319^{\text {**** }} \\
(0.0245)\end{array}$ & $\begin{array}{c}-0.1600^{* * * *} \\
(0.0252)\end{array}$ & $\begin{array}{c}-0.1504^{* * *} \\
(0.0216)\end{array}$ \\
\hline $\begin{array}{l}\text { Currently } \\
\text { Working }\end{array}$ & $\begin{array}{l}-0.0127 \\
(0.0099)\end{array}$ & $\begin{array}{c}0.0048 \\
(0.0155)\end{array}$ & $\begin{array}{l}-0.0105 \\
(0.0158)\end{array}$ & $\begin{array}{l}-0.0022 \\
(0.0088)\end{array}$ & $\begin{array}{c}0.0041 \\
(0.0152)\end{array}$ & $\begin{array}{l}-0.0020 \\
(0.0128)\end{array}$ & $\begin{array}{c}0.0099 \\
(0.0176)\end{array}$ & $\begin{array}{l}-0.0135 \\
(0.0091)\end{array}$ \\
\hline $\begin{array}{l}\text { City Size: } \\
\text { 50,000-99,999 }\end{array}$ & $\begin{array}{l}-0.0105 \\
(0.0156)\end{array}$ & $\begin{array}{l}-0.0401^{*} \\
(0.0222)\end{array}$ & $\begin{array}{l}-0.0093 \\
(0.0248)\end{array}$ & $\begin{array}{l}-0.0208 \\
(0.0172)\end{array}$ & $\begin{array}{l}-0.0175 \\
(0.0201)\end{array}$ & $\begin{array}{l}-0.0364 \\
(0.0322)\end{array}$ & $\begin{array}{l}-0.0137 \\
(0.0235)\end{array}$ & $\begin{array}{l}-0.0091 \\
(0.0156)\end{array}$ \\
\hline $\begin{array}{l}\text { City Size: } \\
\text { 100,000-499,999 }\end{array}$ & $\begin{array}{l}-0.0048 \\
(0.0148)\end{array}$ & $\begin{array}{c}0.0101 \\
(0.0229)\end{array}$ & $\begin{array}{l}-0.0535^{* *} \\
(0.0218)\end{array}$ & $\begin{array}{l}-0.0219^{* *} \\
(0.0102)\end{array}$ & $\begin{array}{l}-0.0019 \\
(0.0199)\end{array}$ & $\begin{array}{c}0.0062 \\
(0.0261)\end{array}$ & $\begin{array}{l}-0.0379^{* *} \\
(0.0186)\end{array}$ & $\begin{array}{l}-0.0043 \\
(0.0154)\end{array}$ \\
\hline $\begin{array}{l}\text { City Size: } \\
500,000+\end{array}$ & $\begin{array}{l}-0.0033 \\
(0.0146)\end{array}$ & $\begin{array}{l}-0.0042 \\
(0.0218)\end{array}$ & $\begin{array}{l}-0.0398^{*} \\
(0.0208)\end{array}$ & $\begin{array}{l}-0.0107 \\
(0.0113)\end{array}$ & $\begin{array}{l}-0.0388^{* *} \\
(0.0191)\end{array}$ & $\begin{array}{l}-0.0323 \\
(0.0245)\end{array}$ & $\begin{array}{c}-0.0493^{* * *} \\
(0.0186)\end{array}$ & $\begin{array}{l}-0.0392^{* *} \\
(0.0159)\end{array}$ \\
\hline Inner City & $\begin{array}{l}-0.0219 \\
(0.0161)\end{array}$ & $\begin{array}{c}0.0045 \\
(0.0188)\end{array}$ & $\begin{array}{c}0.0079 \\
(0.0150)\end{array}$ & $\begin{array}{c}0.0048 \\
(0.0075)\end{array}$ & $\begin{array}{l}-0.0333^{*} \\
(0.0179)\end{array}$ & $\begin{array}{l}-0.0047 \\
(0.0210)\end{array}$ & $\begin{array}{l}-0.0101 \\
(0.0201)\end{array}$ & $\begin{array}{l}-0.0075 \\
(0.0123)\end{array}$ \\
\hline Observations & 6,012 & 6,123 & 6,130 & 6,129 & 5,973 & 6,095 & 6,099 & 6,106 \\
\hline
\end{tabular}


Table 5A. The Impact of Perceived Personal Economic Conditions on Attitudes towards Foreigners regarding their Rights: Models with Contact variables and Nazi States in 1928

\begin{tabular}{|c|c|c|c|c|c|c|}
\hline & \multicolumn{2}{|c|}{$\begin{array}{c}\text { Foreigners living in Germany } \\
\text { Should... }\end{array}$} & \multirow{2}{*}{$\begin{array}{c}\text { (3) } \\
\text { Jewish } \\
\text { people living } \\
\text { in Germany } \\
\text { should not } \\
\text { have the } \\
\text { same rights } \\
\text { as Germans }\end{array}$} & \multirow{2}{*}{$\begin{array}{c}(4) \\
\text { Ethnic } \\
\text { Germans from } \\
\text { Eastern Europe } \\
\text { living in } \\
\text { Germany } \\
\text { should not } \\
\text { have the same } \\
\text { rights as } \\
\text { Germans }\end{array}$} & \multirow{2}{*}{$\begin{array}{c}\text { (5) } \\
\text { Turkish } \\
\text { people } \\
\text { living in } \\
\text { Germany } \\
\text { should not } \\
\text { have the } \\
\text { same rights } \\
\text { as Germans }\end{array}$} & \multirow{2}{*}{$\begin{array}{l}\text { (6) } \\
\text { Italians living } \\
\text { in Germany } \\
\text { should not } \\
\text { have the } \\
\text { same rights } \\
\text { as Germans }\end{array}$} \\
\hline & $\begin{array}{c}\text {...marry } \\
\text { only people } \\
\text { of their own } \\
\text { nationality }\end{array}$ & $\begin{array}{c}\text {...not be } \\
\text { allowed to } \\
\text { take part in } \\
\text { any political } \\
\text { activity }\end{array}$ & & & & \\
\hline & \multicolumn{6}{|c|}{ Panel A } \\
\hline $\begin{array}{l}\text { Good Personal } \\
\text { Economic Conditions }\end{array}$ & $\begin{array}{l}-0.0272^{* * *} \\
(0.0071)\end{array}$ & $\begin{array}{l}-0.0374^{* * *} \\
(0.0069)\end{array}$ & $\begin{array}{l}-0.0507^{* * * *} \\
(0.0129)\end{array}$ & $\begin{array}{c}-0.0332^{* * * *} \\
(0.0125)\end{array}$ & $\begin{array}{c}-0.0680^{* * * *} \\
(0.0140)\end{array}$ & $\begin{array}{l}-0.0287^{\text {*** }} \\
(0.0135)\end{array}$ \\
\hline $\begin{array}{l}\text { Bad Personal } \\
\text { Economic Conditions }\end{array}$ & $\begin{array}{l}0.0242^{* *} \\
(0.0119)\end{array}$ & $\begin{array}{c}0.0459^{* * *} \\
(0.0101)\end{array}$ & $\begin{array}{c}0.0634^{* * * *} \\
(0.0194)\end{array}$ & $\begin{array}{c}0.0644^{* * *} \\
(0.0243)\end{array}$ & $\begin{array}{l}0.0463^{* * *} \\
(0.0215)\end{array}$ & $\begin{array}{l}0.0481^{* *} \\
(0.0238)\end{array}$ \\
\hline Observations & 13,146 & 13,102 & 5,905 & 6,100 & 6,090 & 6,096 \\
\hline $\begin{array}{l}\text { Good Personal } \\
\text { Economic Conditions }\end{array}$ & $\begin{array}{l}-0.0241^{* * * *} \\
(0.0070)\end{array}$ & $\begin{array}{l}-0.0347^{\text {**** }} \\
(0.0071)\end{array}$ & $\begin{array}{c}\mathrm{Pa} \\
-0.0462^{* * * *} \\
(0.0137)\end{array}$ & $\begin{array}{l}-0.0312^{* *} \\
(0.0130)\end{array}$ & $\begin{array}{l}-0.0654^{\text {**** }} \\
(0.0150)\end{array}$ & $\begin{array}{l}-0.0239^{*} \\
(0.0137)\end{array}$ \\
\hline $\begin{array}{l}\text { Bad Personal } \\
\text { Economic Conditions }\end{array}$ & $\begin{array}{l}0.0274^{* *} \\
(0.0118)\end{array}$ & $\begin{array}{c}0.0467^{* * *} \\
(0.0111)\end{array}$ & $\begin{array}{l}0.0645^{* * *} \\
(0.0195)\end{array}$ & $\begin{array}{l}0.0641^{* *} \\
(0.0244)\end{array}$ & $\begin{array}{l}0.0421^{* *} \\
(0.0207)\end{array}$ & $\begin{array}{l}0.0489^{* *} \\
(0.0245)\end{array}$ \\
\hline $\begin{array}{l}\text { Foreign Contact at } \\
\text { Work }\end{array}$ & $\begin{array}{c}-0.0311^{* * * *} \\
(0.0080)\end{array}$ & $\begin{array}{c}-0.0565^{* * * *} \\
(0.0083)\end{array}$ & $\begin{array}{l}-0.0294^{* *} \\
(0.0116)\end{array}$ & $\begin{array}{l}-0.0196 \\
(0.0137)\end{array}$ & $\begin{array}{c}-0.0454^{* * *} \\
(0.0150)\end{array}$ & $\begin{array}{c}-0.0185 \\
(0.0146)\end{array}$ \\
\hline Observations & 12,834 & 12,796 & 5,764 & 5,946 & 5,936 & 5,942 \\
\hline $\begin{array}{l}\text { Good Personal } \\
\text { Economic Conditions }\end{array}$ & $\begin{array}{l}-0.0226^{* * * *} \\
(0.0078)\end{array}$ & $\begin{array}{l}-0.0375^{* * * *} \\
(0.0089)\end{array}$ & $\begin{array}{c}\mathrm{Pa} \\
-0.0468^{* * * *} \\
(0.0136)\end{array}$ & $\begin{array}{l}-0.0318^{* *} \\
(0.0130)\end{array}$ & $\begin{array}{l}-0.0648^{* * * *} \\
(0.0151)\end{array}$ & $\begin{array}{l}-0.0241^{*} \\
(0.0136)\end{array}$ \\
\hline $\begin{array}{l}\text { Bad Personal } \\
\text { Economic Conditions }\end{array}$ & $\begin{array}{l}0.0297^{* *} \\
(0.0128)\end{array}$ & $\begin{array}{l}0.0467^{* * * *} \\
(0.0123)\end{array}$ & $\begin{array}{l}0.0623^{* * * *} \\
(0.0194)\end{array}$ & $\begin{array}{l}0.0647^{* * * *} \\
(0.0243)\end{array}$ & $\begin{array}{l}0.0421^{* *} \\
(0.0209)\end{array}$ & $\begin{array}{c}0.0486^{*} \\
(0.0245)\end{array}$ \\
\hline $\begin{array}{l}\text { Foreign Contact at } \\
\text { Work }\end{array}$ & $\begin{array}{c}-0.0297^{* * * *} \\
(0.0089)\end{array}$ & $\begin{array}{c}-0.0498^{* * * *} \\
(0.0095)\end{array}$ & $\begin{array}{l}-0.0250^{* * *} \\
(0.0122)\end{array}$ & $\begin{array}{l}-0.0124 \\
(0.0149)\end{array}$ & $\begin{array}{l}-0.0400^{* *} \\
(0.0162)\end{array}$ & $\begin{array}{l}-0.0148 \\
(0.0150)\end{array}$ \\
\hline $\begin{array}{l}\text { Foreign Contact in } \\
\text { Family }\end{array}$ & $\begin{array}{c}-0.0511^{\text {**** }} \\
(0.0097)\end{array}$ & $\begin{array}{c}-0.0497^{* * * *} \\
(0.0152)\end{array}$ & $\begin{array}{c}-0.0472^{* * *} \\
(0.0165)\end{array}$ & $\begin{array}{c}-0.0894^{* * * *} \\
(0.0161)\end{array}$ & $\begin{array}{c}-0.0645^{* * * *} \\
(0.0172)\end{array}$ & $\begin{array}{c}-0.0483^{* * * *} \\
(0.0140)\end{array}$ \\
\hline Nazi State in 1928 & $\begin{array}{l}-0.0091 \\
(0.0113)\end{array}$ & $\begin{array}{l}-0.0017 \\
(0.0151)\end{array}$ & $\begin{array}{l}0.0673^{* * * *} \\
(0.0210)\end{array}$ & $\begin{array}{c}0.0217 \\
(0.0268)\end{array}$ & $\begin{array}{c}0.0400 \\
(0.0347)\end{array}$ & $\begin{array}{l}0.0497^{* *} \\
(0.0240)\end{array}$ \\
\hline
\end{tabular}

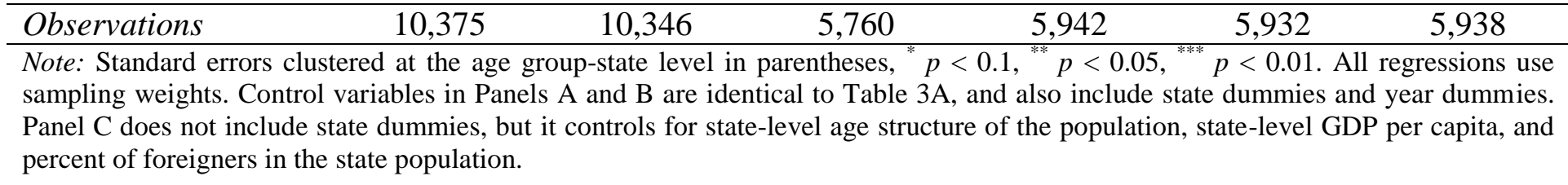


Table 5B. The Impact of Perceived Personal Economic Conditions on Attitudes towards Foreigners Regarding Marriage and Family: Models with Contact variables and Nazi States in 1928
(1)
(2)
(3)
(4)
(5)
(6)
(7)
(8)
It would be unpleasant to have neighbor who is
It would be unpleasant if a ... person married into the family

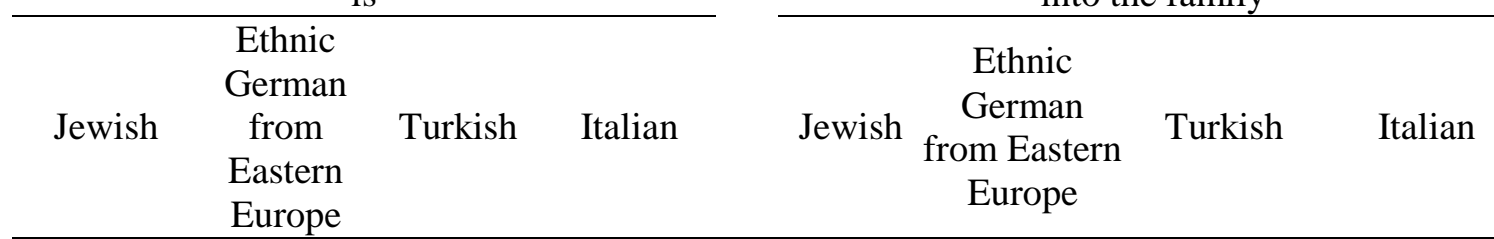

Good Personal

\begin{tabular}{cccccccc}
\multicolumn{8}{c}{ Panel A } \\
\hline$-0.0339^{* * * *}$ & $-0.0543^{* * *}-0.0500^{* * *}$ & $-0.0170^{* *}$ & $-0.0230^{* *}$ & $-0.0417^{* * *}$ & $-0.0254^{*}$ & $-0.0281^{* * * *}$ \\
$(0.0088)$ & $(0.0139)$ & $(0.0140)$ & $(0.0077)$ & $(0.0131)$ & $(0.0126)$ & $(0.0142)$ & $(0.0101)$ \\
$0.0258^{*}$ & -0.0125 & 0.0183 & -0.0022 & 0.0183 & 0.0213 & -0.0119 & $0.0264^{*}$ \\
$(0.0137)$ & $(0.0196)$ & $(0.0234)$ & $(0.0107)$ & $(0.0189)$ & $(0.0188)$ & $(0.0213)$ & $(0.0152)$
\end{tabular}

Econ Conditions

Bad Personal

5,985

6,107

$6,111 \quad 6,120$

\section{Panel B}

Good Personal

$-0.0349^{* * * *}-0.0528^{* * * *}-0.0520^{* * * *}-0.0162^{* * *}$

$-0.0224^{*}-0.0444^{* * * *}$

$\begin{array}{lllll}(0.0089) & (0.0140) & (0.0142) & (0.0074)\end{array}$

$(0.0133)$

(0.0127)

$-0.0280^{*}-0.0311^{* * *}$

Econ Conditions

$\begin{array}{lllll}0.0256^{*} & -0.0148 & 0.0157 & -0.0014\end{array}$

Bad Personal

Econ Conditions

$$
\begin{array}{llll}
(0.0139) & (0.0198) & (0.0236) & (0.0113)
\end{array}
$$

Foreign Contact at

$-0.0280^{* * *}-0.0296^{* *}-0.0611^{* * *}-0.0216^{* * *}$

$0.0168 \quad 0.0187$

(0.0149)

(0.0104)

Work

$$
\begin{array}{lllll}
(0.0098) & (0.0131) & (0.0140) & (0.0071)
\end{array}
$$

(0.0188) (0.0193)

$-0.0154$

0.0246

$-0.0561^{* * *}$

$(0.0213)$

$(0.0159)$

\begin{tabular}{lcccccccc}
\hline Observations & 5,870 & 5,974 & 5,981 & 5,981 & 5,832 & 5,947 & 5,952 & 5,960 \\
\hline \multirow{7}{*}{ Good Personal } & $-0.0349^{* * * *}$ & $-0.0531^{* * *}$ & $-0.0539^{* * *}$ & $-0.0162^{* *}$ & -0.0217 & $-0.0448^{* * *}$ & $-0.0289^{*}$ & $-0.0313^{* * *}$ \\
Econ Conditions & $(0.0089)$ & $(0.0141)$ & $(0.0137)$ & $(0.0076)$ & $(0.0134)$ & $(0.0129)$ & $(0.0149)$ & $(0.0104)$ \\
Bad Personal & $0.0251^{*}$ & -0.0141 & 0.0186 & -0.0001 & 0.0161 & 0.0206 & -0.0134 & 0.0261 \\
Econ Conditions & $(0.0138)$ & $(0.0197)$ & $(0.0237)$ & $(0.0112)$ & $(0.0187)$ & $(0.0192)$ & $(0.0214)$ & $(0.0159)$ \\
Foreign Contact at & $-0.0247^{* * *}$ & $-0.0258^{* *}-0.0552^{* * *}$ & $-0.0205^{* * *}$ & $-0.0519^{* * *}$ & $-0.0296^{* *}$ & $-0.0643^{* * *}$ & $-0.0249^{* *}$ \\
Work & $(0.0098)$ & $(0.0130)$ & $(0.0146)$ & $(0.0072)$ & $(0.0124)$ & $(0.0149)$ & $(0.0118)$ & $(0.0108)$ \\
Foreign Contact in & $-0.0345^{* * *}$ & $-0.0567^{* * *}$ & $-0.0925^{* * *}$ & $-0.0162^{* * *}$ & $-0.0368^{* * *}$ & $-0.1156^{* * *}$ & $-0.1027^{* * *}$ & $-0.0394^{* * *}$ \\
Family & $(0.0098)$ & $(0.0091)$ & $(0.0173)$ & $(0.0053)$ & $(0.0139)$ & $(0.0139)$ & $(0.0161)$ & $(0.0121)$ \\
Nazi State in 1928 & $0.0299^{* *}$ & 0.0073 & 0.0184 & 0.0065 & 0.0322 & -0.0102 & -0.0021 & 0.0119 \\
& $(0.0135)$ & $(0.0214)$ & $(0.0229)$ & $(0.0106)$ & $(0.0324)$ & $(0.0270)$ & $(0.0351)$ & $(0.0161)$ \\
\hline Observations & 5,866 & 5,970 & 5,977 & 5,977 & 5,828 & 5,943 & 5,948 & 5,956 \\
\hline
\end{tabular}

Note: Standard errors clustered at the age group-state level in parentheses, ${ }^{*} p<0.1,{ }^{* * *} p<0.05,{ }^{* * *} p<0.01$. All regressions use sampling weights. Control variables in Panels A and B are identical to Table 3A, and also include state dummies and year dummies. Panel C does not include state dummies, but it controls for state-level age structure of the population, state-level GDP per capita, and percent of foreigners in the state population 
Table 6

Intense Dislike of Others as an Outcome

\begin{tabular}{|c|c|c|c|}
\hline & $\begin{array}{c}\text { (1) } \\
\text { Intense Dislike } \\
\text { of Foreigners }\end{array}$ & $\begin{array}{c}(2) \\
\text { Intense Dislike of } \\
\text { Equal Rights }\end{array}$ & $\begin{array}{c}\text { (3) } \\
\text { Intense Dislike } \\
\text { of Intermarriage }\end{array}$ \\
\hline $\begin{array}{l}\text { Good Personal } \\
\text { Economic Conditions }\end{array}$ & $\begin{array}{l}-0.0146^{* * * *} \\
(0.0047)\end{array}$ & $\begin{array}{c}\text { Panel A } \\
-0.0247^{* * * *} \\
(0.0066)\end{array}$ & $\begin{array}{l}-0.0109^{* *} \\
(0.0052)\end{array}$ \\
\hline $\begin{array}{l}\text { Bad Personal } \\
\text { Economic Conditions }\end{array}$ & $\begin{array}{c}0.0303^{* * *} \\
(0.0108)\end{array}$ & $\begin{array}{l}0.0312^{* *} \\
(0.0142)\end{array}$ & $\begin{array}{l}0.0242^{* * *} \\
(0.0095)\end{array}$ \\
\hline Observations & 13,029 & 5,864 & 5954 \\
\hline $\begin{array}{l}\text { Good Personal } \\
\text { Economic Conditions }\end{array}$ & $\begin{array}{l}-0.0130^{* * * *} \\
(0.0049)\end{array}$ & $\begin{array}{c}\text { Panel B } \\
-0.0228^{* * * *} \\
(0.0065)\end{array}$ & $\begin{array}{l}-0.0116^{* *} \\
(0.0052)\end{array}$ \\
\hline $\begin{array}{l}\text { Bad Personal } \\
\text { Economic Conditions }\end{array}$ & $\begin{array}{l}0.0330^{* * *} \\
(0.0109)\end{array}$ & $\begin{array}{l}0.0339^{* *} \\
(0.0143)\end{array}$ & $\begin{array}{l}0.0253^{* *} \\
(0.0101)\end{array}$ \\
\hline Foreign Contact at Work & $\begin{array}{c}-0.0213^{* * *} \\
(0.0052)\end{array}$ & $\begin{array}{l}-0.0069 \\
(0.0073)\end{array}$ & $\begin{array}{l}-0.0074 \\
(0.0052)\end{array}$ \\
\hline Observations & 12,725 & 5,727 & 5805 \\
\hline $\begin{array}{l}\text { Good Personal } \\
\text { Economic Conditions }\end{array}$ & $\begin{array}{c}-0.0163^{* * * * F^{*}} \\
(0.0060)\end{array}$ & $\begin{array}{c}\text { Panel C } \\
-0.0234^{\text {*a* }} \\
(0.0064)\end{array}$ & $\begin{array}{l}-0.0120^{\text {*** }} \\
(0.0053)\end{array}$ \\
\hline $\begin{array}{l}\text { Bad Personal } \\
\text { Economic Conditions }\end{array}$ & $\begin{array}{l}0.0359^{* * *} \\
(0.0114)\end{array}$ & $\begin{array}{l}0.0338^{* *} \\
(0.0144)\end{array}$ & $\begin{array}{l}0.0259^{* * *} \\
(0.0102)\end{array}$ \\
\hline $\begin{array}{l}\text { Foreign Contact at } \\
\text { Work }\end{array}$ & $\begin{array}{c}-0.0185^{* * * *} \\
(0.0063)\end{array}$ & $\begin{array}{l}-0.0031 \\
(0.0077)\end{array}$ & $\begin{array}{l}-0.0057 \\
(0.0052)\end{array}$ \\
\hline $\begin{array}{l}\text { Foreign Contact in } \\
\text { Family }\end{array}$ & $\begin{array}{c}-0.0382^{* * *} \\
(0.0077)\end{array}$ & $\begin{array}{c}-0.0363^{* * * *} \\
(0.0054)\end{array}$ & $\begin{array}{l}-0.0212^{* * * *} \\
(0.0055)\end{array}$ \\
\hline Nazi State in 1928 & $\begin{array}{l}-0.0014 \\
(0.0095)\end{array}$ & $\begin{array}{c}0.0082 \\
(0.0107)\end{array}$ & $\begin{array}{l}-0.0031 \\
(0.0124)\end{array}$ \\
\hline Observations & 10,291 & 5,723 & 5801 \\
\hline
\end{tabular}

Note: Standard errors clustered at the age group-state level in parentheses, ${ }^{*} p<0.1,{ }^{* * *} p<0.05,{ }^{\text {,*** }} p<0.01$.

All regressions use sampling weights. Intense Dislike of Foreigners is a dummy variable that is equal to one if the individual thinks that foreigners should choose to marry people of their own nationality and that any kind of political participation for foreigners should be prohibited. Intense Dislike of Intermarriage is a dummy variable equal to one if the individual thinks that foreigners should choose to marry people of their own nationality and that a Jew, Turk, Italian, or Aussiedler marrying into their family would be unpleasant, and zero otherwise. Intense Dislike of Equal Rights is a dummy variable that is equal to one if the individual thinks any kind of political participation for foreigners should be prohibited, and that neither Jews, Turks, Italians, or Aussiedler should have the same rights as Germans, and zero otherwise. Control variables in Panels A and B are identical to Table 3A and also include state dummies and year dummies. Panel C does not include state dummies, but it controls for state-level age structure of the population, state-level GDP per capita, and percent of foreigners in the state population. 
Table 7A. The Impact of Perceived Personal Economic Conditions on Attitudes towards Foreigners regarding their Rights: Excluding Strong Racists

\begin{tabular}{|c|c|c|c|c|c|c|}
\hline & \multicolumn{2}{|c|}{$\begin{array}{c}\text { Foreigners living in Germany } \\
\text { Should... }\end{array}$} & \multirow{2}{*}{$\begin{array}{c}\text { (3) } \\
\text { Jewish } \\
\text { people living } \\
\text { in Germany } \\
\text { should not } \\
\text { have the } \\
\text { same rights } \\
\text { as Germans }\end{array}$} & \multirow{2}{*}{$\begin{array}{c}(4) \\
\text { Ethnic } \\
\text { Germans from } \\
\text { Eastern Europe } \\
\text { living in } \\
\text { Germany } \\
\text { should not } \\
\text { have the same } \\
\text { rights as } \\
\text { Germans }\end{array}$} & \multirow{2}{*}{$\begin{array}{c}(5) \\
\text { Turkish } \\
\text { people } \\
\text { living in } \\
\text { Germany } \\
\text { should not } \\
\text { have the } \\
\text { same rights } \\
\text { as Germans }\end{array}$} & \multirow{2}{*}{$\begin{array}{c}\text { (6) } \\
\text { Italians living } \\
\text { in Germany } \\
\text { should not } \\
\text { have the } \\
\text { same rights } \\
\text { as Germans }\end{array}$} \\
\hline & $\begin{array}{c}\text {...marry } \\
\text { only people } \\
\text { of their own } \\
\text { nationality }\end{array}$ & $\begin{array}{c}\text {...not be } \\
\text { allowed to } \\
\text { take part in } \\
\text { any political } \\
\text { activity }\end{array}$ & & & & \\
\hline & \multicolumn{6}{|c|}{ Panel A } \\
\hline $\begin{array}{l}\text { Good Personal } \\
\text { Economic Conditions }\end{array}$ & $\begin{array}{l}-0.0210^{* * *} \\
(0.0094)\end{array}$ & $\begin{array}{l}-0.0312^{* *} \\
(0.0136)\end{array}$ & $\begin{array}{l}-0.0296^{* *} \\
(0.0118)\end{array}$ & $\begin{array}{l}-0.0094 \\
(0.0124)\end{array}$ & 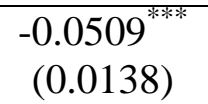 & $\begin{array}{l}-0.0097 \\
(0.0125)\end{array}$ \\
\hline $\begin{array}{l}\text { Bad Personal } \\
\text { Economic Conditions }\end{array}$ & $\begin{array}{c}0.0011 \\
(0.0140)\end{array}$ & $\begin{array}{c}0.0115 \\
(0.0160)\end{array}$ & $\begin{array}{l}0.0422^{* *} \\
(0.0180)\end{array}$ & $\begin{array}{c}0.0426^{*} \\
(0.0221)\end{array}$ & $\begin{array}{c}0.0353 \\
(0.0243)\end{array}$ & $\begin{array}{c}0.0355 \\
(0.0232)\end{array}$ \\
\hline \multirow[t]{2}{*}{ Observations } & 5,186 & 5,186 & 5,186 & 5,186 & 5,186 & 5,186 \\
\hline & \multicolumn{6}{|c|}{ Panel B } \\
\hline $\begin{array}{l}\text { Good Personal } \\
\text { Economic Conditions }\end{array}$ & $\begin{array}{l}-0.0194^{* *} \\
(0.0096)\end{array}$ & $\begin{array}{l}-0.0304^{* * *} \\
(0.0145)\end{array}$ & $\begin{array}{l}-0.0264^{* * *} \\
(0.0123)\end{array}$ & $\begin{array}{c}-0.0072 \\
(0.0122)\end{array}$ & $\begin{array}{l}-0.0494^{* * * *} \\
(0.0145)\end{array}$ & $\begin{array}{l}-0.0055 \\
(0.0127)\end{array}$ \\
\hline $\begin{array}{l}\text { Bad Personal } \\
\text { Economic Conditions }\end{array}$ & $\begin{array}{c}0.0037 \\
(0.0141)\end{array}$ & $\begin{array}{c}0.0067 \\
(0.0181)\end{array}$ & $\begin{array}{l}0.0409^{* * *} \\
(0.0188)\end{array}$ & $\begin{array}{c}0.0437^{*} \\
(0.0223)\end{array}$ & $\begin{array}{c}0.0338 \\
(0.0229)\end{array}$ & $\begin{array}{c}0.0357 \\
(0.0239)\end{array}$ \\
\hline $\begin{array}{l}\text { Foreign Contact at } \\
\text { Work }\end{array}$ & $\begin{array}{l}-0.0228^{*} \\
(0.0116)\end{array}$ & $\begin{array}{c}-0.0476^{* * *} \\
(0.0119)\end{array}$ & $\begin{array}{l}-0.0271^{* *} \\
(0.0106)\end{array}$ & $\begin{array}{l}-0.0217 \\
(0.0159)\end{array}$ & $\begin{array}{l}-0.0448^{* * *} \\
(0.0154)\end{array}$ & $\begin{array}{l}-0.0152 \\
(0.0173)\end{array}$ \\
\hline \multirow[t]{2}{*}{ Observations } & 5,067 & 5,067 & 5,067 & 5,067 & 5,067 & 5,067 \\
\hline & \multicolumn{6}{|c|}{ Panel C } \\
\hline $\begin{array}{l}\text { Good Personal } \\
\text { Economic Conditions }\end{array}$ & $\begin{array}{l}-0.0210^{* *} \\
(0.0095)\end{array}$ & $\begin{array}{l}-0.0297^{* *} \\
(0.0148)\end{array}$ & $\begin{array}{l}-0.0267^{* *} \\
(0.0122)\end{array}$ & $\begin{array}{l}-0.0082 \\
(0.0123)\end{array}$ & $\begin{array}{l}-0.0484^{* * * * *} \\
(0.0146)\end{array}$ & $\begin{array}{l}-0.0054 \\
(0.0127)\end{array}$ \\
\hline $\begin{array}{l}\text { Bad Personal } \\
\text { Economic Conditions }\end{array}$ & $\begin{array}{c}0.0044 \\
(0.0141)\end{array}$ & $\begin{array}{c}0.0059 \\
(0.0183)\end{array}$ & $\begin{array}{l}0.0393^{* *} \\
(0.0187)\end{array}$ & $\begin{array}{l}0.0439^{*} \\
(0.0223)\end{array}$ & $\begin{array}{c}0.0354 \\
(0.0230)\end{array}$ & $\begin{array}{c}0.0358 \\
(0.0238)\end{array}$ \\
\hline $\begin{array}{l}\text { Foreign Contact at } \\
\text { Work }\end{array}$ & $\begin{array}{l}-0.0222^{*} \\
(0.0115)\end{array}$ & $\begin{array}{c}-0.0450^{* * * *} \\
(0.0115)\end{array}$ & $\begin{array}{l}-0.0248^{* * *} \\
(0.0111)\end{array}$ & $\begin{array}{l}-0.0171 \\
(0.0169)\end{array}$ & $\begin{array}{l}-0.0403^{* *} \\
(0.0164)\end{array}$ & $\begin{array}{l}-0.0143 \\
(0.0174)\end{array}$ \\
\hline $\begin{array}{l}\text { Foreign Contact in } \\
\text { Family }\end{array}$ & $\begin{array}{l}-0.0151 \\
(0.0123)\end{array}$ & $\begin{array}{l}-0.0256 \\
(0.0181)\end{array}$ & $\begin{array}{l}-0.0186 \\
(0.0153)\end{array}$ & $\begin{array}{l}-0.0590^{* * * *} \\
(0.0155)\end{array}$ & $\begin{array}{l}-0.0527^{* * *} \\
(0.0180)\end{array}$ & $\begin{array}{l}-0.0192 \\
(0.0136)\end{array}$ \\
\hline Nazi State in 1928 & $\begin{array}{c}0.0038 \\
(0.0169)\end{array}$ & $\begin{array}{c}0.0165 \\
(0.0249)\end{array}$ & $\begin{array}{l}0.0663^{* * * *} \\
(0.0193)\end{array}$ & $\begin{array}{c}0.0213 \\
(0.0249)\end{array}$ & $\begin{array}{c}0.0378 \\
(0.0358)\end{array}$ & $\begin{array}{l}0.0477^{* *} \\
(0.0231)\end{array}$ \\
\hline
\end{tabular}

Observations 5,063
Note: Standard errors clustered at the age group-state level in parentheses, ${ }^{*} p<0.1,{ }^{* *} p<0.05,{ }^{* * * *} p<0.01$. All regressions use
sampling weights. Regressions exclude individuals for whom Intense Dislike of Intermarriage = 1 or Intense Dislike of Equal Rights =
1. Control variables in Panels A and B are identical to Table 3A, and also include state dummies and year dummies. Panel C does not
include state dummies, but controls for state-level age structure of the population, state-level GDP per capita, and percent of foreigners
in the state population.


Table 7B. The Impact of Perceived Personal Economic Conditions on Attitudes towards Foreigners Regarding Marriage and Family: Excluding Strong Racists
(1)
(2)
(4)
(5)
(6)

(7)

(8)

It would be unpleasant to have neighbor who is

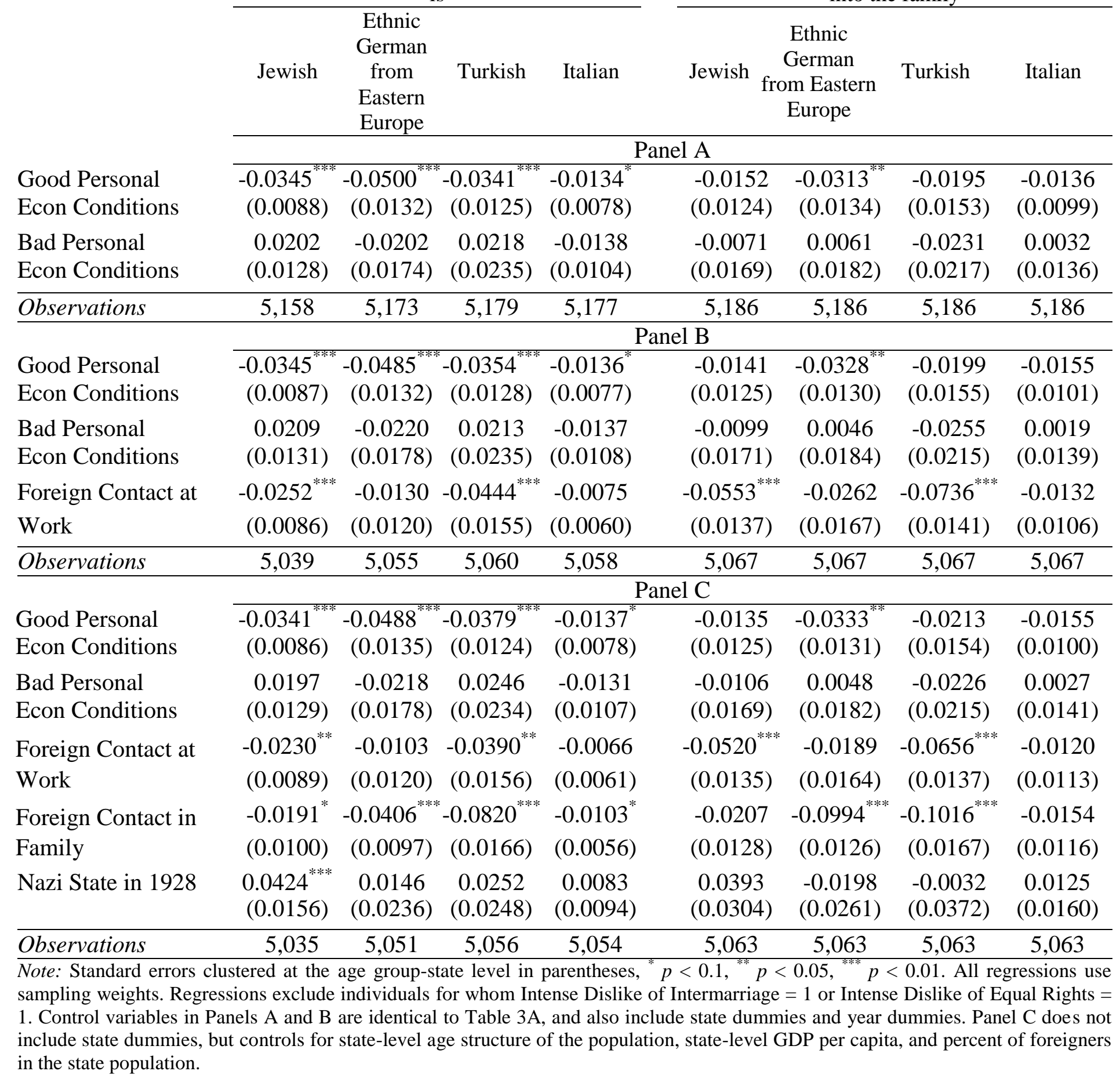

It would be unpleasant if a ... person married into the family 
Table 8A. The Impact of Perceived Personal Economic Conditions on Attitudes towards Foreigners regarding their Rights: Detailed Employment Classifications

\begin{tabular}{|c|c|c|c|c|c|c|}
\hline & \multicolumn{2}{|c|}{$\begin{array}{c}\text { Foreigners living in Germany } \\
\text { Should... }\end{array}$} & \multirow{2}{*}{$\begin{array}{c}\text { (3) } \\
\text { Jewish people } \\
\text { living in } \\
\text { Germany } \\
\text { should not } \\
\text { have the same } \\
\text { rights as } \\
\text { Germans }\end{array}$} & \multirow{2}{*}{$\begin{array}{c}(4) \\
\text { Ethnic } \\
\text { Germans from } \\
\text { Eastern } \\
\text { Europe living } \\
\text { in Germany } \\
\text { should not } \\
\text { have the same } \\
\text { rights as } \\
\text { Germans }\end{array}$} & \multirow{2}{*}{$\begin{array}{c}\text { (5) } \\
\text { Turkish people } \\
\text { living in } \\
\text { Germany } \\
\text { should not } \\
\text { have the same } \\
\text { rights as } \\
\text { Germans }\end{array}$} & \multirow{2}{*}{$\begin{array}{c}(6) \\
\text { Italians living } \\
\text { in Germany } \\
\text { should not } \\
\text { have the same } \\
\text { rights as } \\
\text { Germans }\end{array}$} \\
\hline & $\begin{array}{l}\text {...marry only } \\
\text { people of } \\
\text { their own } \\
\text { nationality }\end{array}$ & $\begin{array}{l}\text {...not be } \\
\text { allowed to } \\
\text { take part in } \\
\text { any political } \\
\text { activity }\end{array}$ & & & & \\
\hline $\begin{array}{l}\text { Good Personal } \\
\text { Economic Conditions }\end{array}$ & $\begin{array}{l}-0.0205^{* * *} \\
(0.0072)\end{array}$ & $\begin{array}{l}-0.0282^{* * *} \\
(0.0070)\end{array}$ & $\begin{array}{l}-0.0443^{* * *} \\
(0.0133)\end{array}$ & $\begin{array}{l}-0.0283^{* *} \\
(0.0133)\end{array}$ & $\begin{array}{l}-0.0629^{* * *} \\
(0.0149)\end{array}$ & $\begin{array}{l}-0.0214 \\
(0.0135)\end{array}$ \\
\hline $\begin{array}{l}\text { Bad Personal } \\
\text { Economic Conditions }\end{array}$ & $\begin{array}{l}0.0287^{* *} \\
(0.0120)\end{array}$ & $\begin{array}{l}0.0460^{* * *} \\
(0.0106)\end{array}$ & $\begin{array}{l}0.0626^{* * *} \\
(0.0201)\end{array}$ & $\begin{array}{l}0.0636^{* *} \\
(0.0246)\end{array}$ & $\begin{array}{l}0.0429^{* *} \\
(0.0198)\end{array}$ & $\begin{array}{l}0.0488^{* *} \\
(0.0238)\end{array}$ \\
\hline $\begin{array}{l}\text { Self-employed } \\
\text { Farmer }\end{array}$ & $\begin{array}{c}0.0148 \\
(0.0471)\end{array}$ & $\begin{array}{l}0.1630^{* *} \\
(0.0785)\end{array}$ & $\begin{array}{l}0.1987^{*} \\
(0.1006)\end{array}$ & $\begin{array}{c}0.1040 \\
(0.0915)\end{array}$ & $\begin{array}{l}0.2115^{* * *} \\
(0.0702)\end{array}$ & $\begin{array}{l}0.1963^{*} \\
(0.1034)\end{array}$ \\
\hline $\begin{array}{l}\text { Self-employed } \\
\text { Professional }\end{array}$ & $\begin{array}{c}-0.0426^{* * *} \\
(0.0148)\end{array}$ & $\begin{array}{c}-0.0975^{* * *} \\
(0.0294)\end{array}$ & $\begin{array}{l}-0.0544 \\
(0.0434)\end{array}$ & $\begin{array}{l}-0.0553 \\
(0.0601)\end{array}$ & $\begin{array}{l}-0.0708 \\
(0.0746)\end{array}$ & $\begin{array}{l}-0.0381 \\
(0.0685)\end{array}$ \\
\hline $\begin{array}{l}\text { Other } \\
\text { Self-employed }\end{array}$ & $\begin{array}{l}-0.0218 \\
(0.0134)\end{array}$ & $\begin{array}{c}0.0037 \\
(0.0204)\end{array}$ & $\begin{array}{c}0.0139 \\
(0.0224)\end{array}$ & $\begin{array}{l}-0.0056 \\
(0.0272)\end{array}$ & $\begin{array}{l}-0.0155 \\
(0.0279)\end{array}$ & $\begin{array}{l}-0.0015 \\
(0.0328)\end{array}$ \\
\hline $\begin{array}{l}\text { Civil Servant } \\
\text { or Military }\end{array}$ & $\begin{array}{c}-0.0448^{* * *} \\
(0.0117)\end{array}$ & $\begin{array}{l}-0.0800^{* * *} \\
(0.0170)\end{array}$ & $\begin{array}{l}-0.0024 \\
(0.0323)\end{array}$ & $\begin{array}{l}-0.0317 \\
(0.0300)\end{array}$ & $\begin{array}{l}-0.0275 \\
(0.0324)\end{array}$ & $\begin{array}{l}-0.0192 \\
(0.0280)\end{array}$ \\
\hline Employee & $\begin{array}{l}-0.0041 \\
(0.0087)\end{array}$ & $\begin{array}{l}-0.0155 \\
(0.0094)\end{array}$ & $\begin{array}{c}0.0266 \\
(0.0167)\end{array}$ & $\begin{array}{c}0.0199 \\
(0.0180)\end{array}$ & $\begin{array}{c}0.0100 \\
(0.0181)\end{array}$ & $\begin{array}{c}0.0080 \\
(0.0142)\end{array}$ \\
\hline Laborer & $\begin{array}{l}0.0381^{* * *} \\
(0.0132)\end{array}$ & $\begin{array}{l}0.0473^{* * *} \\
(0.0152)\end{array}$ & $\begin{array}{l}0.0383^{*} \\
(0.0213)\end{array}$ & $\begin{array}{c}0.0230 \\
(0.0236)\end{array}$ & $\begin{array}{c}0.0362 \\
(0.0224)\end{array}$ & $\begin{array}{l}0.0421^{*} \\
(0.0226)\end{array}$ \\
\hline In Training & $\begin{array}{l}-0.0267 \\
(0.0205)\end{array}$ & $\begin{array}{c}0.0267 \\
(0.0428)\end{array}$ & $\begin{array}{l}-0.0711 \\
(0.0461)\end{array}$ & $\begin{array}{l}-0.0736 \\
(0.0544)\end{array}$ & $\begin{array}{l}-0.0414 \\
(0.0718)\end{array}$ & $\begin{array}{l}-0.0871^{*} \\
(0.0452)\end{array}$ \\
\hline $\begin{array}{l}\text { Foreign Contact } \\
\text { at Work }\end{array}$ & $\begin{array}{c}-0.0367^{* * * *} \\
(0.0082)\end{array}$ & $\begin{array}{c}-0.0589^{* * *} \\
(0.0079)\end{array}$ & $\begin{array}{c}-0.0314^{* * * *} \\
(0.0108)\end{array}$ & $\begin{array}{l}-0.0210 \\
(0.0132)\end{array}$ & $\begin{array}{c}-0.0499^{* * *} \\
(0.0148)\end{array}$ & $\begin{array}{l}-0.0200 \\
(0.0155)\end{array}$ \\
\hline
\end{tabular}

Note: Standard errors clustered at the age group-state level in parentheses, ${ }^{*} p<0.1,{ }^{* * *} p<0.05,{ }^{* * *} p<0.01$. All specifications also include controls for the individual's age, gender, marital status, education, city size, and whether the individual lives in the inner city. All regressions use sampling weights, and also include state fixed effects and year dummies. 
Table 8B: The Impact of Perceived Personal Economic Conditions on Attitudes towards Foreigners regarding Marriage and Family: Detailed Employment Classifications

(1)

(2)

(3)

(4)

(5)

(6)

(7)

It would be unpleasant if a ... person married

It would be unpleasant to have neighbor who is

\begin{tabular}{|c|c|c|c|c|c|c|c|c|}
\hline & Jewish & $\begin{array}{c}\text { Ethnic } \\
\text { German } \\
\text { from } \\
\text { Eastern } \\
\text { Europe }\end{array}$ & Turkish & Italian & Jewish & $\begin{array}{c}\text { Ethnic } \\
\text { German } \\
\text { from } \\
\text { Eastern } \\
\text { Europe } \\
\end{array}$ & Turkish & Italian \\
\hline $\begin{array}{l}\text { Good Personal } \\
\text { Economic Conditions }\end{array}$ & $\begin{array}{l}-0.0327^{* * *} \\
(0.0088)\end{array}$ & $\begin{array}{l}-0.0515^{* * *} \\
(0.0140)\end{array}$ & $\begin{array}{l}-0.0528^{* * *} \\
(0.0143)\end{array}$ & $\begin{array}{l}-0.0162^{* *} \\
(0.0075)\end{array}$ & $\begin{array}{l}-0.0166 \\
(0.0131)\end{array}$ & $\begin{array}{l}-0.0438^{* * * *} \\
(0.0130)\end{array}$ & $\begin{array}{l}-0.0290^{*} \\
(0.0148)\end{array}$ & $\begin{array}{l}-0.0290^{* * *} \\
(0.0105)\end{array}$ \\
\hline $\begin{array}{l}\text { Bad Personal } \\
\text { Economic Conditions }\end{array}$ & $\begin{array}{l}0.0246^{*} \\
(0.0141)\end{array}$ & $\begin{array}{l}-0.0125 \\
(0.0199)\end{array}$ & $\begin{array}{c}0.0179 \\
(0.0230)\end{array}$ & $\begin{array}{l}-0.0027 \\
(0.0114)\end{array}$ & $\begin{array}{c}0.0120 \\
(0.0183)\end{array}$ & $\begin{array}{c}0.0181 \\
(0.0191)\end{array}$ & $\begin{array}{l}-0.0167 \\
(0.0214)\end{array}$ & $\begin{array}{c}0.0225 \\
(0.0154)\end{array}$ \\
\hline $\begin{array}{l}\text { Self-employed } \\
\text { Farmer }\end{array}$ & $\begin{array}{c}0.1021 \\
(0.0661)\end{array}$ & $\begin{array}{c}0.0443 \\
(0.0805)\end{array}$ & $\begin{array}{c}0.0916 \\
(0.0801)\end{array}$ & $\begin{array}{c}0.0673 \\
(0.0543)\end{array}$ & $\begin{array}{l}0.3980^{* * * *} \\
(0.0792)\end{array}$ & $\begin{array}{c}0.1044 \\
(0.0851)\end{array}$ & $\begin{array}{l}0.1588^{* *} \\
(0.0700)\end{array}$ & $\begin{array}{l}0.2057^{* * *} \\
(0.0768)\end{array}$ \\
\hline $\begin{array}{l}\text { Self-employed } \\
\text { Professional }\end{array}$ & $\begin{array}{l}-0.0672^{* * *} \\
(0.0120)\end{array}$ & $\begin{array}{c}0.0036 \\
(0.0459)\end{array}$ & $\begin{array}{l}-0.0916^{*} \\
(0.0514)\end{array}$ & $\begin{array}{c}0.0164 \\
(0.0322)\end{array}$ & $\begin{array}{l}-0.0870^{* *} \\
(0.0373)\end{array}$ & $\begin{array}{c}0.0119 \\
(0.0590)\end{array}$ & $\begin{array}{l}-0.0630 \\
(0.0789)\end{array}$ & $\begin{array}{l}-0.0241 \\
(0.0411)\end{array}$ \\
\hline $\begin{array}{l}\text { Other } \\
\text { Self-employed }\end{array}$ & $\begin{array}{l}-0.0270 \\
(0.0185)\end{array}$ & $\begin{array}{c}0.0207 \\
(0.0310)\end{array}$ & $\begin{array}{l}-0.0218 \\
(0.0357)\end{array}$ & $\begin{array}{l}-0.0010 \\
(0.0166)\end{array}$ & $\begin{array}{c}0.0166 \\
(0.0253)\end{array}$ & $\begin{array}{c}0.0034 \\
(0.0262)\end{array}$ & $\begin{array}{l}-0.0313 \\
(0.0298)\end{array}$ & $\begin{array}{l}-0.0215 \\
(0.0164)\end{array}$ \\
\hline $\begin{array}{l}\text { Civil Servant } \\
\text { or Military }\end{array}$ & $\begin{array}{l}-0.0442^{* *} \\
(0.0182)\end{array}$ & $\begin{array}{l}-0.0023 \\
(0.0294)\end{array}$ & $\begin{array}{l}-0.0189 \\
(0.0368)\end{array}$ & $\begin{array}{l}-0.0005 \\
(0.0193)\end{array}$ & $\begin{array}{l}-0.0172 \\
(0.0249)\end{array}$ & $\begin{array}{c}0.0233 \\
(0.0338)\end{array}$ & $\begin{array}{c}0.0597 \\
(0.0444)\end{array}$ & $\begin{array}{l}-0.0011 \\
(0.0168)\end{array}$ \\
\hline Employee & $\begin{array}{c}0.0046 \\
(0.0107)\end{array}$ & $\begin{array}{l}0.0300^{*} \\
(0.0179)\end{array}$ & $\begin{array}{l}0.0446^{* *} \\
(0.0214)\end{array}$ & $\begin{array}{l}-0.0027 \\
(0.0089)\end{array}$ & $\begin{array}{c}0.0052 \\
(0.0164)\end{array}$ & $\begin{array}{c}0.0096 \\
(0.0150)\end{array}$ & $\begin{array}{c}0.0250 \\
(0.0186)\end{array}$ & $\begin{array}{l}-0.0163^{*} \\
(0.0091)\end{array}$ \\
\hline Laborer & $\begin{array}{c}0.0217 \\
(0.0146)\end{array}$ & $\begin{array}{l}-0.0087 \\
(0.0198)\end{array}$ & $\begin{array}{c}0.0146 \\
(0.0254)\end{array}$ & $\begin{array}{l}-0.0043 \\
(0.0123)\end{array}$ & $\begin{array}{l}0.0529^{* *} \\
(0.0219)\end{array}$ & $\begin{array}{c}0.0176 \\
(0.0194)\end{array}$ & $\begin{array}{l}0.0667^{* * *} \\
(0.0198)\end{array}$ & $\begin{array}{c}0.0237 \\
(0.0179)\end{array}$ \\
\hline In Training & $\begin{array}{c}0.0120 \\
(0.0287)\end{array}$ & $\begin{array}{l}-0.0344 \\
(0.0507)\end{array}$ & $\begin{array}{c}0.0326 \\
(0.0471)\end{array}$ & $\begin{array}{l}-0.0194 \\
(0.0191)\end{array}$ & $\begin{array}{c}0.0050 \\
(0.0380)\end{array}$ & $\begin{array}{c}0.0519 \\
(0.0316)\end{array}$ & $\begin{array}{l}0.1022^{*} \\
(0.0558)\end{array}$ & $\begin{array}{c}0.0076 \\
(0.0439)\end{array}$ \\
\hline $\begin{array}{l}\text { Foreign Contact } \\
\text { at Work }\end{array}$ & $\begin{array}{c}-0.0310^{* * *} \\
(0.0093)\end{array}$ & $\begin{array}{l}-0.0291^{* *} \\
(0.0134)\end{array}$ & $\begin{array}{c}-0.0652^{* * *} \\
(0.0137)\end{array}$ & $\begin{array}{c}-0.0202^{* * *} \\
(0.0066)\end{array}$ & $\begin{array}{c}-0.0549^{* * *} \\
(0.0127)\end{array}$ & $\begin{array}{l}-0.0382^{* *} \\
(0.0152)\end{array}$ & $\begin{array}{c}-0.0752^{\text {**** }} \\
(0.0125)\end{array}$ & $\begin{array}{c}-0.0278^{* * *} \\
(0.0105)\end{array}$ \\
\hline Observations & 5,811 & 5,914 & 5,922 & 5,921 & 5,774 & 5,888 & 5,892 & 5,900 \\
\hline
\end{tabular}




\section{Table 9A. The Impact of Perceived Personal Economic Conditions on Attitudes towards}

Foreigners regarding their Rights: Excluding the Self-Employed

\begin{tabular}{|c|c|c|c|c|c|c|}
\hline & \multicolumn{2}{|c|}{$\begin{array}{c}\text { Foreigners living in Germany } \\
\text { Should... }\end{array}$} & \multirow{2}{*}{$\begin{array}{c}(3) \\
\text { Jewish } \\
\text { people living } \\
\text { in Germany } \\
\text { should not } \\
\text { have the } \\
\text { same rights } \\
\text { as Germans }\end{array}$} & \multirow{2}{*}{$\begin{array}{c}(4) \\
\text { Ethnic } \\
\text { Germans from } \\
\text { Eastern Europe } \\
\text { living in } \\
\text { Germany } \\
\text { should not } \\
\text { have the same } \\
\text { rights as } \\
\text { Germans }\end{array}$} & \multirow{2}{*}{$\begin{array}{c}(5) \\
\text { Turkish } \\
\text { people } \\
\text { living in } \\
\text { Germany } \\
\text { should not } \\
\text { have the } \\
\text { same rights } \\
\text { as Germans }\end{array}$} & \multirow{2}{*}{$\begin{array}{c}\text { (6) } \\
\text { Italians living } \\
\text { in Germany } \\
\text { should not } \\
\text { have the } \\
\text { same rights } \\
\text { as Germans }\end{array}$} \\
\hline & $\begin{array}{c}\text {...marry } \\
\text { only people } \\
\text { of their own } \\
\text { nationality }\end{array}$ & $\begin{array}{c}\ldots \text {...not be } \\
\text { allowed to } \\
\text { take part in } \\
\text { any political } \\
\text { activity }\end{array}$ & & & & \\
\hline & \multicolumn{6}{|c|}{ Panel A } \\
\hline $\begin{array}{l}\text { Good Personal } \\
\text { Economic Conditions }\end{array}$ & $\begin{array}{l}-0.0306 \text { *** } \\
(0.0077)\end{array}$ & $\begin{array}{l}-0.0371^{* * * * *} \\
(0.0076)\end{array}$ & $\begin{array}{l}-0.0481^{* * * *} \\
(0.0131)\end{array}$ & $\begin{array}{c}-0.0277^{* *} \\
(0.0131)\end{array}$ & $\begin{array}{l}-0.0690^{* * *} \\
(0.0142)\end{array}$ & $\begin{array}{l}-0.0274^{*} \\
(0.0144)\end{array}$ \\
\hline $\begin{array}{l}\text { Bad Personal } \\
\text { Economic Conditions }\end{array}$ & $\begin{array}{l}0.0239^{* *} \\
(0.0118)\end{array}$ & $\begin{array}{c}0.0473^{* * *} \\
(0.0115)\end{array}$ & $\begin{array}{c}0.0635^{* * * *} \\
(0.0218)\end{array}$ & $\begin{array}{l}0.0631^{* *} \\
(0.0263)\end{array}$ & $\begin{array}{l}0.0492^{* *} \\
(0.0217)\end{array}$ & $\begin{array}{l}0.0465^{*} \\
(0.0236)\end{array}$ \\
\hline \multirow[t]{2}{*}{ Observations } & 12,220 & 12,181 & 5,485 & 5,658 & 5,648 & 5,656 \\
\hline & \multicolumn{6}{|c|}{ Panel B } \\
\hline $\begin{array}{l}\text { Good Personal } \\
\text { Economic Conditions }\end{array}$ & $\begin{array}{l}-0.0275^{* * * * *} \\
(0.0075)\end{array}$ & $\begin{array}{l}-0.0344^{* * *} \\
(0.0077)\end{array}$ & $\begin{array}{l}-0.0441^{* * * *} \\
(0.0139)\end{array}$ & $\begin{array}{l}-0.0253^{*} \\
(0.0136)\end{array}$ & $\begin{array}{c}-0.0672^{* * * * *} \\
(0.0154)\end{array}$ & $\begin{array}{l}-0.0229 \\
(0.0146)\end{array}$ \\
\hline $\begin{array}{l}\text { Bad Personal } \\
\text { Economic Conditions }\end{array}$ & $\begin{array}{l}0.0275^{* *} \\
(0.0116)\end{array}$ & $\begin{array}{l}0.0483^{* * * *} \\
(0.0122)\end{array}$ & $\begin{array}{l}0.0642^{* * * *} \\
(0.0219)\end{array}$ & $\begin{array}{l}0.0631^{* * *} \\
(0.0264)\end{array}$ & $\begin{array}{l}0.0446^{* *} \\
(0.0208)\end{array}$ & $\begin{array}{c}0.0469^{*} \\
(0.0244)\end{array}$ \\
\hline $\begin{array}{l}\text { Foreign Contact at } \\
\text { Work }\end{array}$ & $\begin{array}{c}-0.0319^{* * * *} \\
(0.0092)\end{array}$ & $\begin{array}{c}-0.0603^{* * *} \\
(0.0084)\end{array}$ & $\begin{array}{c}-0.0319^{* * * *} \\
(0.0118)\end{array}$ & $\begin{array}{l}-0.0157 \\
(0.0143)\end{array}$ & $\begin{array}{c}-0.0475^{* * *} \\
(0.0156)\end{array}$ & $\begin{array}{l}-0.0207 \\
(0.0160)\end{array}$ \\
\hline \multirow[t]{2}{*}{ Observations } & 11,910 & 11,877 & 5,346 & 5,506 & 5,496 & 5,504 \\
\hline & \multicolumn{6}{|c|}{ Panel C } \\
\hline $\begin{array}{l}\text { Good Personal } \\
\text { Economic Conditions }\end{array}$ & $\begin{array}{r}-0.0277^{*} \\
(0.0082)\end{array}$ & $\begin{array}{c}-0.0375 \\
(0.0095)\end{array}$ & $\begin{array}{c}-0.0455^{*} \\
(0.0139)\end{array}$ & $\begin{array}{l}-0.0266 \\
(0.0136)\end{array}$ & $\begin{array}{r}-0.0677^{*} \\
(0.0155)\end{array}$ & $\begin{array}{l}-0.0236 \\
(0.0145)\end{array}$ \\
\hline $\begin{array}{l}\text { Bad Personal } \\
\text { Economic Conditions }\end{array}$ & $\begin{array}{l}0.0329^{* * * *} \\
(0.0125)\end{array}$ & $\begin{array}{l}0.0504^{* * * *} \\
(0.0138)\end{array}$ & $\begin{array}{l}0.0628^{* * *} \\
(0.0219)\end{array}$ & $\begin{array}{l}0.0641^{* *} \\
(0.0261)\end{array}$ & $\begin{array}{l}0.0452^{* *} \\
(0.0211)\end{array}$ & $\begin{array}{c}0.0465^{*} \\
(0.0245)\end{array}$ \\
\hline $\begin{array}{l}\text { Foreign Contact at } \\
\text { Work }\end{array}$ & $\begin{array}{c}-0.0304^{* * * *} \\
(0.0094)\end{array}$ & $\begin{array}{c}-0.0535^{* * * *} \\
(0.0093)\end{array}$ & $\begin{array}{l}-0.0273^{* *} \\
(0.0121)\end{array}$ & $\begin{array}{l}-0.0085 \\
(0.0154)\end{array}$ & $\begin{array}{l}-0.0417^{* *} \\
(0.0168)\end{array}$ & $\begin{array}{l}-0.0174 \\
(0.0167)\end{array}$ \\
\hline $\begin{array}{l}\text { Foreign Contact in } \\
\text { Family }\end{array}$ & $\begin{array}{c}-0.0536^{* * * *} \\
(0.0103)\end{array}$ & $\begin{array}{c}-0.0486^{* * * *} \\
(0.0147)\end{array}$ & $\begin{array}{c}-0.0496^{* * *} \\
(0.0178)\end{array}$ & $\begin{array}{c}-0.0895^{* * *} \\
(0.0176)\end{array}$ & $\begin{array}{c}-0.0669^{* * * *} \\
(0.0190)\end{array}$ & $\begin{array}{c}-0.0493^{* * *} \\
(0.0166)\end{array}$ \\
\hline Nazi State in 1928 & $\begin{array}{l}-0.0089 \\
(0.0111)\end{array}$ & $\begin{array}{l}-0.0030 \\
(0.0171)\end{array}$ & $\begin{array}{l}0.0629^{* * *} \\
(0.0227)\end{array}$ & $\begin{array}{c}0.0238 \\
(0.0275)\end{array}$ & $\begin{array}{c}0.0408 \\
(0.0351)\end{array}$ & $\begin{array}{l}0.0537^{* *} \\
(0.0237)\end{array}$ \\
\hline Observations & 9,623 & 9,598 & 5,343 & 5,503 & 5,493 & 5,501 \\
\hline
\end{tabular}


Table 9B. The Impact of Perceived Personal Economic Conditions on Attitudes towards Foreigners Regarding Marriage and Family: Excluding the Self-Employed

\begin{tabular}{|c|c|c|c|c|c|c|c|c|}
\hline & \multirow{2}{*}{\multicolumn{4}{|c|}{$\begin{array}{ccc}(1) & (2) & (3) \\
\text { It would be unpleasant to have neighbor who } \\
\text { is }\end{array}$}} & \multirow{2}{*}{\multicolumn{4}{|c|}{$\begin{array}{l}\text { It would be unpleasant if a ... person married } \\
\text { into the family }\end{array}$}} \\
\hline & & & & & & & & \\
\hline & Jewish & $\begin{array}{c}\text { Ethnic } \\
\text { German } \\
\text { from } \\
\text { Eastern } \\
\text { Europe }\end{array}$ & Turkish & Italian & Jewish & $\begin{array}{l}\text { Ethnic } \\
\text { German } \\
\text { om Eastern } \\
\text { Europe }\end{array}$ & Turkish & Italian \\
\hline \multirow[b]{2}{*}{$\begin{array}{l}\text { Good Personal } \\
\text { Econ Conditions }\end{array}$} & \multicolumn{8}{|c|}{ Panel A } \\
\hline & $\begin{array}{c}-0.0376^{* * * *} \\
(0.0097)\end{array}$ & $\begin{array}{r}-0.0476^{* * *} \\
(0.0140)\end{array}$ & $\begin{array}{l}{ }^{*}-0.0510^{* * * *} \\
(0.0153)\end{array}$ & $\begin{array}{l}-0.0144^{*} \\
(0.0085)\end{array}$ & & $\begin{array}{c}-0.0392^{* * *} \\
(0.0145)\end{array}$ & $\begin{array}{l}-0.0297^{* *} \\
(0.0147)\end{array}$ & $\begin{array}{c}-0.0277^{* * * *} \\
(0.0102)\end{array}$ \\
\hline & & & & & & & $\begin{array}{l}-0.0171 \\
(0.0219)\end{array}$ & \\
\hline \multirow[t]{2}{*}{ Observations } & 5,586 & 5,687 & 5,695 & 5,695 & 5,551 & 5,665 & 5,669 & 5,677 \\
\hline & \multicolumn{8}{|c|}{ Panel B } \\
\hline $\begin{array}{l}\text { Good Personal } \\
\text { Econ Conditions }\end{array}$ & $\begin{array}{c}-0.0395^{* * * * *} \\
(0.0099)\end{array}$ & $\begin{array}{r}-0.0460^{* * *} \\
(0.0141)\end{array}$ & $\begin{array}{r}-0.0538^{* * * * *} \\
(0.0153)\end{array}$ & $\begin{array}{l}-0.0142^{*} \\
(0.0084)\end{array}$ & & $\begin{array}{c}-0.0417^{* * * *} \\
(0.0146)\end{array}$ & $\begin{array}{l}-0.0332^{* *} \\
(0.0154)\end{array}$ & $\begin{array}{r}-0.0312^{* * * *} \\
(0.0107)\end{array}$ \\
\hline $\begin{array}{l}\text { Bad Person } \\
\text { Econ Cond }\end{array}$ & $\begin{array}{c}0.0233 \\
(0.0155)\end{array}$ & $\begin{array}{l}-0.0106 \\
(0.0202)\end{array}$ & $\begin{array}{c}0.0191 \\
(0.0237)\end{array}$ & & & $\begin{array}{c}0.0178 \\
(0.0188)\end{array}$ & $\begin{array}{c}-0.0209 \\
(0.0219)\end{array}$ & $\begin{array}{c}0.0236 \\
(0.0166)\end{array}$ \\
\hline Foreign Contact at & $-0.0284^{* * *}$ & $-0.0252^{*}$ & $-0.0625^{* * *}$ & $-0.0214^{* * *}$ & $-0.0449^{* * *}$ & $-0.0322^{*}$ & $-0.0686^{* * *}$ & $-0.0190^{*}$ \\
\hline Work & $(0.0099)$ & $(0.0144)$ & $(0.0148)$ & $(0.0069)$ & $(0.0119)$ & $(0.0173)$ & $(0.0126)$ & $(0.0101)$ \\
\hline \multirow[t]{2}{*}{ Observations } & 5,434 & 5,529 & 5,537 & 5,537 & 5,400 & 5,507 & 5,512 & 5,519 \\
\hline & \multicolumn{8}{|c|}{ Panel C } \\
\hline $\begin{array}{l}\text { Good Personal } \\
\text { Econ Conditions }\end{array}$ & $\begin{array}{c}-0.0399^{* * * *} \\
(0.0098)\end{array}$ & $\begin{array}{r}-0.0464^{* * *} \\
(0.0142)\end{array}$ & $\begin{array}{c}{ }^{*}-0.0559^{* * * *} \\
(0.0149)\end{array}$ & $\begin{array}{l}-0.0144^{*} \\
(0.0086)\end{array}$ & $\begin{array}{l}-0.0222 \\
(0.0141)\end{array}$ & $\begin{array}{c}-0.0430^{* * * *} \\
(0.0147)\end{array}$ & $\begin{array}{c}-0.0347^{* *} \\
(0.0154)\end{array}$ & $\begin{array}{c}-0.0319^{* * *} \\
(0.0105)\end{array}$ \\
\hline $\begin{array}{l}\text { Bad Pe } \\
\text { Econ C }\end{array}$ & $\begin{array}{c}0.0232 \\
(0.0155)\end{array}$ & $\begin{array}{l}-0.0096 \\
(0.0202)\end{array}$ & $\begin{array}{c}0.0231 \\
(0.0240)\end{array}$ & $\begin{array}{l}-0.0022 \\
(0.0119)\end{array}$ & $\begin{array}{c}0.0118 \\
(0.0191)\end{array}$ & $\begin{array}{c}0.0213 \\
(0.0185)\end{array}$ & $\begin{array}{l}-0.0171 \\
(0.0222)\end{array}$ & $\begin{array}{c}0.0258 \\
(0.0168)\end{array}$ \\
\hline $\begin{array}{l}\text { Foreign Contact at } \\
\text { Work }\end{array}$ & $\begin{array}{c}-0.0253^{* *} \\
(0.0099)\end{array}$ & $\begin{array}{l}-0.0218 \\
(0.0143)\end{array}$ & $\begin{array}{c}-0.0562^{* * * *} \\
(0.0154)\end{array}$ & $\begin{array}{c}-0.0204^{* * * *} \\
(0.0069)\end{array}$ & $-0.0416^{* * *}$ & -0.0247 & $-0.0607^{* * *}$ & $\begin{array}{l}-0.0167 \\
(0.0104)\end{array}$ \\
\hline Foreign Contact in & $-0.0343^{* * * *}$ & $-0.0595^{* * *}$ & $-0.0933^{* * * *}$ & $-0.0172^{* * * *}$ & $-0.0332^{* * *}$ & $-0.1194^{* * * *}$ & $-0.1006^{* * * *}$ & $-0.0396^{* * * *}$ \\
\hline & $(0.0103)$ & $(0.0106)$ & $(0.0180)$ & & $(0.0162)$ & $(0.0151)$ & $(0.0165)$ & $(0.0132)$ \\
\hline Nazi State in 1928 & $\begin{array}{c}0.0218 \\
(0.0153)\end{array}$ & $\begin{array}{l}-0.0008 \\
(0.0235)\end{array}$ & $\begin{array}{c}0.0237 \\
(0.0241)\end{array}$ & $\begin{array}{c}0.0057 \\
(0.0108)\end{array}$ & $\begin{array}{c}0.0308 \\
(0.0346)\end{array}$ & $\begin{array}{c}-0.0209 \\
(0.0285)\end{array}$ & $\begin{array}{l}-0.0078 \\
(0.0368)\end{array}$ & $\begin{array}{c}0.0121 \\
(0.0171)\end{array}$ \\
\hline Uoservanons & 5,431 & 5,526 & 5,534 & 5,534 & 5,397 & 5,504 & 5,509 & 5,516 \\
\hline
\end{tabular}

Note: Standard errors clustered at the age group-state level in parentheses, ${ }^{*} p<0.1,{ }^{* * *} p<0.05,{ }^{* * * *} p<0.01$. All regressions use sampling weights. Control variables in Panels A and B are identical to Table $3 \mathrm{~A}$ and also include state dummies and year dummies. Panel C does not include state dummies, but controls for state-level age structure of the population, state-level GDP per capita, and percent of foreigners in the state population. 
Table 10. The Impact of Perceived Personal Economic Conditions on Opinions about Women's Labor Market Attachment (Male-only Sample)

\begin{tabular}{|c|c|c|c|c|c|}
\hline & $(1)$ & $(2)$ & $(3)$ & $(4)$ & $(5)$ \\
\hline & $\begin{array}{l}\text { More important for a } \\
\text { woman to help } \\
\text { husband's career, } \\
\text { than have a career } \\
\text { herself } \\
\end{array}$ & $\begin{array}{c}\text { An infant will } \\
\text { certainly suffer if } \\
\text { the mother is } \\
\text { working in the } \\
\text { market }\end{array}$ & $\begin{array}{l}\text { Better if husband } \\
\text { works and wife } \\
\text { stays home tending } \\
\text { to household and } \\
\text { children }\end{array}$ & $\begin{array}{c}\text { It is not good for a } \\
\text { child if the mother is } \\
\text { working in market } \\
\text { instead of concentrating } \\
\text { on household }\end{array}$ & $\begin{array}{l}\text { A married woman } \\
\text { should give up } \\
\text { working if jobs are } \\
\text { scarce and husband can } \\
\text { provide for family } \\
\end{array}$ \\
\hline Good Personal & -0.0158 & -0.0143 & 0.0077 & 0.0366 & -0.0056 \\
\hline Economic Conditions & $(0.0194)$ & $(0.0185)$ & $(0.0186)$ & $(0.0239)$ & $(0.0179)$ \\
\hline $\begin{array}{l}\text { Bad Personal } \\
\text { Economic Conditions }\end{array}$ & $\begin{array}{l}-0.0299 \\
(0.0321)\end{array}$ & $\begin{array}{l}-0.0199 \\
(0.0289)\end{array}$ & $\begin{array}{c}0.0388 \\
(0.0372)\end{array}$ & $\begin{array}{c}0.0062 \\
(0.0426)\end{array}$ & $\begin{array}{c}0.0598 \\
(0.0483)\end{array}$ \\
\hline $\begin{array}{l}\text { Foreign Contact at } \\
\text { Work }\end{array}$ & $\begin{array}{l}-0.0016 \\
(0.0198)\end{array}$ & $\begin{array}{l}-0.0283^{*} \\
(0.0158)\end{array}$ & $\begin{array}{l}-0.0241 \\
(0.0227)\end{array}$ & $\begin{array}{l}-0.0523^{* *} \\
(0.0258)\end{array}$ & $\begin{array}{l}-0.0171 \\
(0.0213)\end{array}$ \\
\hline $\begin{array}{l}\text { Foreign Contact in } \\
\text { Family }\end{array}$ & $\begin{array}{c}0.0021 \\
(0.0252)\end{array}$ & $\begin{array}{l}-0.0369^{*} \\
(0.0214)\end{array}$ & $\begin{array}{l}-0.0158 \\
(0.0287)\end{array}$ & $\begin{array}{l}-0.0475 \\
(0.0359)\end{array}$ & $\begin{array}{l}-0.0207 \\
(0.0227)\end{array}$ \\
\hline Nazi State in 1928 & $\begin{array}{c}0.0327 \\
(0.0315)\end{array}$ & $\begin{array}{c}0.0338 \\
(0.0372)\end{array}$ & $\begin{array}{l}-0.0010 \\
(0.0369)\end{array}$ & $\begin{array}{c}0.0139 \\
(0.0338)\end{array}$ & $\begin{array}{l}-0.0219 \\
(0.0297)\end{array}$ \\
\hline Age & $\begin{array}{l}0.0101^{* *} \\
(0.0048)\end{array}$ & $\begin{array}{c}0.0060 \\
(0.0039)\end{array}$ & $\begin{array}{l}0.0107^{* * *} \\
(0.0040)\end{array}$ & $\begin{array}{c}0.0034 \\
(0.0044)\end{array}$ & $\begin{array}{c}0.0068^{*} \\
(0.0040)\end{array}$ \\
\hline Age-squared & $\begin{array}{l}-0.0000 \\
(0.0001)\end{array}$ & $\begin{array}{l}-0.0000 \\
(0.0000)\end{array}$ & $\begin{array}{l}-0.0000 \\
(0.0000)\end{array}$ & $\begin{array}{l}-0.0000 \\
(0.0000)\end{array}$ & $\begin{array}{c}0.0000 \\
(0.0000)\end{array}$ \\
\hline Married & $\begin{array}{c}0.0101 \\
(0.0190)\end{array}$ & $\begin{array}{l}0.0528^{* *} \\
(0.0217)\end{array}$ & $\begin{array}{c}0.0213 \\
(0.0284)\end{array}$ & $\begin{array}{c}0.0088 \\
(0.0240)\end{array}$ & $\begin{array}{l}-0.0226 \\
(0.0209)\end{array}$ \\
\hline Catholic & $\begin{array}{c}0.0002 \\
(0.0282)\end{array}$ & $\begin{array}{l}-0.0006 \\
(0.0293)\end{array}$ & $\begin{array}{c}0.0145 \\
(0.0308)\end{array}$ & $\begin{array}{c}0.0442 \\
(0.0285)\end{array}$ & $\begin{array}{c}0.0367 \\
(0.0234)\end{array}$ \\
\hline $\begin{array}{l}\text { No Religion/ } \\
\text { Other Religion }\end{array}$ & $\begin{array}{l}-0.0218 \\
(0.0297)\end{array}$ & $\begin{array}{l}-0.0791^{* *} \\
(0.0314)\end{array}$ & $\begin{array}{l}-0.0824^{* * *} \\
(0.0262)\end{array}$ & $\begin{array}{l}-0.0663^{*} \\
(0.0340)\end{array}$ & $\begin{array}{l}-0.0351 \\
(0.0218)\end{array}$ \\
\hline $\begin{array}{l}\text { Education: } \\
\text { Vocational }\end{array}$ & $\begin{array}{l}-0.0378 \\
(0.0293)\end{array}$ & $\begin{array}{c}0.0147 \\
(0.0275)\end{array}$ & $\begin{array}{c}0.0006 \\
(0.0336)\end{array}$ & $\begin{array}{l}-0.0383 \\
(0.0338)\end{array}$ & $\begin{array}{l}-0.0693^{* *} \\
(0.0325)\end{array}$ \\
\hline $\begin{array}{l}\text { Education: } \\
\text { Adv. Technical }\end{array}$ & $\begin{array}{l}-0.0560 \\
(0.0354)\end{array}$ & $\begin{array}{l}-0.0111 \\
(0.0340)\end{array}$ & $\begin{array}{l}-0.0600 \\
(0.0391)\end{array}$ & $\begin{array}{l}-0.0526 \\
(0.0425)\end{array}$ & $\begin{array}{c}-0.1155^{* * *} \\
(0.0417)\end{array}$ \\
\hline $\begin{array}{l}\text { Education: } \\
\text { College }\end{array}$ & $\begin{array}{c}-0.1749^{* * *} \\
(0.0431)\end{array}$ & $\begin{array}{l}-0.0785^{* *} \\
(0.0346)\end{array}$ & $\begin{array}{c}-0.2121^{* * *} \\
(0.0512)\end{array}$ & $\begin{array}{c}-0.1323^{* * *} \\
(0.0436)\end{array}$ & $\begin{array}{c}-0.2268^{* * *} \\
(0.0438)\end{array}$ \\
\hline $\begin{array}{l}\text { Currently } \\
\text { Working }\end{array}$ & $\begin{array}{c}-0.0718^{* * *} \\
(0.0261)\end{array}$ & $\begin{array}{c}0.0014 \\
(0.0240)\end{array}$ & $\begin{array}{l}-0.0446^{* *} \\
(0.0212)\end{array}$ & $\begin{array}{c}0.0092 \\
(0.0234)\end{array}$ & $\begin{array}{l}-0.0282 \\
(0.0263)\end{array}$ \\
\hline $\begin{array}{l}\text { City Size: } \\
50,000-99,999\end{array}$ & $\begin{array}{l}-0.0277 \\
(0.0365)\end{array}$ & $\begin{array}{l}-0.0392 \\
(0.0474)\end{array}$ & $\begin{array}{l}-0.0065 \\
(0.0425)\end{array}$ & $\begin{array}{l}-0.0598 \\
(0.0402)\end{array}$ & $\begin{array}{c}0.0067 \\
(0.0470)\end{array}$ \\
\hline $\begin{array}{l}\text { City Size: } \\
\text { 100,000-499,999 }\end{array}$ & $\begin{array}{c}0.0032 \\
(0.0330)\end{array}$ & $\begin{array}{c}0.0270 \\
(0.0259)\end{array}$ & $\begin{array}{l}-0.0067 \\
(0.0291)\end{array}$ & $\begin{array}{l}0.0627^{* *} \\
(0.0310)\end{array}$ & $\begin{array}{l}-0.0526^{*} \\
(0.0292)\end{array}$ \\
\hline $\begin{array}{l}\text { City Size: } \\
500,000+\end{array}$ & $\begin{array}{l}-0.0521^{* * *} \\
(0.0247)\end{array}$ & $\begin{array}{c}0.0175 \\
(0.0252)\end{array}$ & $\begin{array}{l}-0.0065 \\
(0.0275)\end{array}$ & $\begin{array}{l}-0.0166 \\
(0.0338)\end{array}$ & $\begin{array}{c}-0.0833^{* * * *} \\
(0.0314)\end{array}$ \\
\hline Inner City & $\begin{array}{l}-0.0504^{*} \\
(0.0258)\end{array}$ & $\begin{array}{c}0.0154 \\
(0.0260)\end{array}$ & $\begin{array}{l}-0.0448 \\
(0.0283)\end{array}$ & $\begin{array}{c}0.0089 \\
(0.0353)\end{array}$ & $\begin{array}{c}0.0048 \\
(0.0297)\end{array}$ \\
\hline Observations & 2,341 & 2,401 & 2,400 & 2,332 & 2,378 \\
\hline
\end{tabular}

Note: Standard errors clustered at the age group-state level in parentheses, ${ }^{*} p<0.1,{ }^{* * *} p<0.05,{ }^{* * * *} p<0.01$. All regressions use sampling weights, and also include the same control variables as described in Table 5a, Panel C. 


\section{References}

Akerlof, George A. and Rachel Kranton, 2005 "Identity and the Economics of Organizations." Journal of Economic Perspectives. 19(1): 9-32.

Akerlof, George A. and Rachel Kranton, 2000 "Economics and Identity." Quarterly Journal of Economics. 105(3): 715-53.

Alesina, Alberto, Paola Giuliano, and Nathan Nunn. 2013. "On the Origins of Gender Roles: Women and the Plough.” The Quarterly Journal of Economics 128 (2): 469-530.

Alesina, Alberto, and Paola Giuliano. 2010. "The Power of the Family." Journal of Economic Growth 15 (2): 93-125.

Alesina, Alberto, and Eliana La Ferrara 2005. "Ethnic Diversity and Economic Performance." Journal of Economic Literature 43: 762-800.

Antecol, Heather and Deborah A. Cobb-Clark. 2008." Identity and Racial Harassment." Journal of Economic Behavior and Organization.66: 529-57.

Bottazzi, Laura, Marco Da Rin, and Thomas F. Hellmann. 2011. "The Importance of Trust for Investment: Evidence from Venture Capital”. Working Paper 16923. Cambridge, MA: National Bureau of Economic Research.

Card, David and Christian Dustmann and Ian Preston, 2012. "Immigration, Wages and Compositional Amenities." Journal of the European Economic Association 10(1): 78119.

Card, David and Gordon Dahl, 2011. "Family Violence and Football: The effect of Unexpected Emotional Cues on Violent Behavior." Quarterly Journal of Economics 126: 103-43.

DellaVigna, Stefano. 2009. "Psychology and Economics: Evidence from the Field." Journal of Economic Literature 47: 315-72.

Dustmann, Christian, Francesca Fabbri and Ian Preston. 2011. "Racial Harassment, Ethnic Concentration, and Economic Conditions." Scandinavian Journal of Economics 113(3): 689-711.

Dustmann, Christian and Ian Preston. 2007. "Racial and Economic Factors in Attitudes to Immigration.” The B.E. Journal of Economic Analysis \& Policy: Advances. 7(1). Article 62.

Facchini, Giovanni and Anna Maria Mayda. 2009. "Does the Welfare State Affects Individual Attitudes Towards Immigrants? Evidence Across Countries." The Review of Economics and Statistics. 91(2): 291-314 
Falk, Armin, Andreas Kuhn, and Josef Zweimüller. 2011. "Unemployment and Right-Wing Extremist Crime." Scandinavian Journal of Economics 113 (2): 260-85.

Fernández, Raquel, and Alessandra Fogli. 2009. "Culture: An Empirical Investigation of Beliefs, Work, and Fertility.” American Economic Journal: Macroeconomics 1 (1): 146-77.

Freeman, Richard and Huang Wei. 2014. "Collaborating with people Like Me: Ethnic Coauthorship within the U.S.” NBER Working paper No: 19905.

Frick, Joachim and Gert G. Wagner. 2001. "Deutsche Sprachfähigkeit und Umgangssprache von Zuwanderern." Wochenbericht des DIW Berlin 24/01.

Glaeser, Edward L. 2005. "The Political Economy of Hatred." Quarterly Journal of Economics 120 (1): 45-86.

Green, Donald, Jack Glaser, and Andrew Rich. 1998. "From Lynching to Gay Bashing: The Elusive Connection between Economic Conditions and Hate Crime." Journal of Personality and Social Psychology 75 (1): 82-92.

Guiso, Luigi, Paola Sapienza, and Luigi Zingales. 2006. "Does Culture Affect Economic Outcomes?" Journal of Economic Perspectives 20 (2): 23-48.

—. 2009. “Cultural Biases in Economic Exchange?” Quarterly Journal of Economics 124 (3): 1095-1131.

Helliwell, John F., Shun Wang, and Jinwen Xu. 2014. "How durable are social Norms? Immigrant Trust and Generosity in 132 Countries.” NBER Working Paper 19855. Cambridge, MA: National Bureau of Economic Research.

Hepworth, Joseph T., and Stephen G. West. 1988. "Lynchings and the Economy: A Time-Series Reanalysis of Hovland and Sears (1940).” Journal of Personality and Social Psychology 55 (2): 239-47.

Hong, Lu and Scott E. Page. 2004. "Groups of Diverse Problem Solvers can Outperform Groups of High-Ability problem Solvers.” Proceedings of the National Academy of Sciences. 101(46): 16385-89.

Hovland, Carl Iver, and Robert R. Sears. 1940. "Minor Studies of Aggression: VI. Correlation of Lynchings with Economic Indices.” The Journal of Psychology 9 (2): 301-10.

Humlum, Maria K., Kristin J. Kleinjans and Helena S. Nielsen. 2012. "An Economic Analysis of Identity and Career Choice.” Economic Inquiry 50(1): 39-61 
King, Gary, Ori Rosen, Martin Tanner, and Alexander F. Wagner. 2008. "Ordinary Economic Voting Behavior in the Extraordinary Election of Adolf Hitler." The Journal of Economic History 68 (04): 951.

Krueger, Alan B, and Jörn-Steffen Pischke. 1997. "A Statistical Analysis of Crime against Foreigners in Unified Germany.” Journal of Human Resources: 182-209.

Lazear, Edward. 1999. "Globalisation and the Market for Team-mates." The Economic Journal, 109. C15-C40.

Loewenstein, George. 2000. "Emotions in Economic Theory and Economic Behavior." American Economic Review 90: 426-32.

Luttmer, Erzo F. P, and Monica Singhal. 2011. "Culture, Context, and the Taste for Redistribution.” American Economic Journal: Economic Policy 3 (1): 157-79.

Mayda, Anna Maria. 2006. "Who is Against Immigration? A Cross-Country Investigation of Individual Attitudes Towards Immigrants" Review of Economics and Statistics 88 (3): 510-30.

Mayda, Anna Maria and Dani Rodrik. 2005 "Why are some People (and Countries) more Protectionist than Others?" European Economic Review, 49: 1393-1430.

Mocan, Naci. 2013. "Vengeance." Review of Economics and Statistics 95 (3): 969-82.

Rees, Dan and Kevin Schnepel 2009. "College Football games and Crime." Journal of Sports Economics, 10: 68-86.

Reuters, October 30, 2013. “'Nationalism and Xenophobia' on Rise Ahead of European Elections" by Luke Baker and Stephen Adler. http://www.reuters.com/article/2013/10/30/us-eu-parliament-electionsidUSBRE99T0YZ20131030.

Reuters, November 25, 2013. "Swiss Government Urges Voters to Reject Immigration Quota Plan" by Ruben Sprich. http://www.reuters.com/article/2013/11/25/us-swissimmigration-idUSBRE9AO0IN20131125.

Siedler, Thomas. 2011. "Parental Unemployment and Young People's Extreme Right-Wing Party Affinity: Evidence from Panel Data." Journal of the Royal Statistical Society: Series A (Statistics in Society) 174 (3): 737-58.

The Guardian, March 30, 2013. "EU Warns Cameron over 'Knee-jerk Xenophobia'." By Toby Helm. http://www.theguardian.com/uk/2013/mar/30/eu-cameron-xenophobiaimmigration. 
Vogel, Dita. "Update Report Germany: Estimate Number of Irregular Foreign Residents in Germany (2010)”. Update report. Database on Irregular Migration. http://irregularmigration.net/.

Voigtlaender, Nico, and Hans-Joachim Voth. 2012a. "Persecution Perpetuated: The Medieval Origins of Anti-Semitic Violence in Nazi Germany." Quarterly Journal of Economics 127 (3): 1339-92.

Voigtlaender, Nico, and Hans-Joachim Voth. 2012b. “(Re-)Shaping Hatred: Anti-Semitic Attitudes in Germany-1890-2006. Working Paper. 


\section{Appendix Table 1A. The Impact of Perceived Personal Economic Conditions on Attitudes}

towards Foreigners regarding their Rights: Models with Age Dummies

(1)

\begin{tabular}{cc}
\multicolumn{2}{c}{ Should... } \\
\hline ...marry & ...not be \\
only people & allowed to \\
of their own & take part in \\
nationality & $\begin{array}{c}\text { any political } \\
\text { activity }\end{array}$
\end{tabular}

Good Personal

Economic Conditions

Bad Personal

Economic Conditions

Age: 25-34

Age: 35-44

$-0.0260^{* * *}$

(0.0071)

$0.0238^{*}$

(0.0120)

$0.0711^{* * * *}$

(0.0118)

$0.0926^{* * *}$

(0.0137)

Age: $45-54$

$0.1208^{* * *}$

(0.0134)

Age: 55-64

$0.1680^{* * *}$
$(0.0158)$

$0.2151^{* * * *}$

Age: $65-74$

$$
\text { (0.0150) }
$$

Age: $75+$

$0.2807^{* * *}$

$-0.0373^{* * *}$

(0.0070)

(0.0101)

$0.0485^{\text {**** }}$

(0.0162)

(0.0166)

(0.0160)

(0.0167)

(0.0162)

$0.2334^{\text {**** }}$
(0.0212)
(3)

Jewish people living in

Germany should not

have the same rights as Germans
(4)

Ethnic

Germans from

Eastern

Europe living

in Germany

should not

have the same

rights as

Germans

\section{(5)}

Turkish people living in Germany should not

have the same rights as Germans
(6)

Italians living

in Germany

should not

have the same

rights as

Germans

Germans

$-0.0677^{* * *} \quad-0.0264^{*}$

$-0.0511^{* * *}$

(0.0125)

(0.0143)

(0.0135)

(0.0130)

$0.0654^{* * *}$

$0.0476^{* * *}$

$0.0491^{\text {** }}$

(0.0196)

(0.0244)

(0.0211)

(0.0237)

0.0112

(0.0195)

$0.0818^{* *}$

0.0204

$0.0530^{* *}$

(0.0343)

(0.0343)

(0.0231)

$0.0348^{*}$

$0.0847^{* *}$

$0.0660^{* *}$

$0.0767^{* * *}$

(0.0181)

(0.0350)

(0.0318)

(0.0223)

0.0225

$0.0729^{* *}$

$0.0521^{*}$

0.0295

(0.0198)

(0.0319)

(0.0310)

(0.0222)

$0.0733^{* * *}$

(0.0185)

$0.0940^{* * *}$

$0.1349^{* * *}$

$0.0672^{* * *}$

(0.0323)

(0.0325)

(0.0234)

$0.0985^{* * *}$

$0.0874^{* *}$

$0.1594^{* * *}$

$0.0768^{* * *}$

(0.0238)

(0.0365)

(0.0352)

(0.0243)

$0.0781^{* *}$

$0.0895^{* *}$

$0.2283^{* * *}$

$0.0975^{* * *}$

(0.0233)

(0.0331)

(0.0412)

(0.0487)

(0.0313)

Observations

13,146

13,102

5,905

6,100

6,090

Note: Standard errors clustered at the Agegroup-State level in parentheses, ${ }^{*} p<0.1,{ }^{* *} p<0.05,{ }^{* * *} p<0.01$. All specifications also include controls for the individual's age, gender, marital status, education, city size, and whether the individual lives in the inner city. The omitted age category is 18-24 year olds. All regressions use sampling weights, and also include state fixed effects and year dummies. 


\section{Appendix Table 1B. The Impact of Perceived Personal Economic Conditions on Attitudes towards Foreigners regarding Marriage and Family: Models with Age Dummies}
(1)
(2)
(3)
(4)
(6)

(7)

(8)

It would be unpleasant to have neighbor who is

\begin{tabular}{|c|c|c|c|c|c|c|c|c|}
\hline & Jewish & $\begin{array}{c}\text { Ethnic } \\
\text { German } \\
\text { from } \\
\text { Eastern } \\
\text { Europe }\end{array}$ & Turkish & Italian & Jewish & $\begin{array}{c}\text { Ethnic } \\
\text { German } \\
\text { from } \\
\text { Eastern } \\
\text { Europe }\end{array}$ & Turkish & Italian \\
\hline $\begin{array}{l}\text { Good Personal } \\
\text { Economic Conditions }\end{array}$ & $\begin{array}{l}-0.0335^{* * * *} \\
(0.0088)\end{array}$ & $\begin{array}{l}-0.0530^{* * * *} \\
(0.0137)\end{array}$ & $\begin{array}{l}-0.0507^{* * * *} \\
(0.0139)\end{array}$ & $\begin{array}{l}-0.0167^{* *} \\
(0.0078)\end{array}$ & $\begin{array}{l}-0.0249^{*} \\
(0.0130)\end{array}$ & $\begin{array}{l}-0.0423^{* * * *} \\
(0.0124)\end{array}$ & $\begin{array}{l}-0.0306^{* *} \\
(0.0147)\end{array}$ & $\begin{array}{l}-0.0269^{* * *} \\
(0.0103)\end{array}$ \\
\hline $\begin{array}{l}\text { Bad Personal } \\
\text { Economic Conditions }\end{array}$ & $\begin{array}{l}0.0258^{*} \\
(0.0137)\end{array}$ & $\begin{array}{l}-0.0113 \\
(0.0196)\end{array}$ & $\begin{array}{c}0.0184 \\
(0.0235)\end{array}$ & $\begin{array}{l}-0.0017 \\
(0.0111)\end{array}$ & $\begin{array}{c}0.0203 \\
(0.0187)\end{array}$ & $\begin{array}{c}0.0220 \\
(0.0187)\end{array}$ & $\begin{array}{l}-0.0088 \\
(0.0209)\end{array}$ & $\begin{array}{c}0.0251 \\
(0.0152)\end{array}$ \\
\hline Age: $25-34$ & $\begin{array}{c}0.0186 \\
(0.0159)\end{array}$ & $\begin{array}{l}0.0631^{* *} \\
(0.0315)\end{array}$ & $\begin{array}{l}-0.0091 \\
(0.0346)\end{array}$ & $\begin{array}{c}0.0123 \\
(0.0173)\end{array}$ & $\begin{array}{c}0.0240 \\
(0.0228)\end{array}$ & $\begin{array}{c}0.0498 \\
(0.0308)\end{array}$ & $\begin{array}{l}-0.0459 \\
(0.0390)\end{array}$ & $\begin{array}{l}0.0478^{*} \\
(0.0244)\end{array}$ \\
\hline Age: $35-44$ & $\begin{array}{c}0.0245 \\
(0.0150)\end{array}$ & $\begin{array}{c}0.0425 \\
(0.0284)\end{array}$ & $\begin{array}{c}0.0083 \\
(0.0323)\end{array}$ & $\begin{array}{l}0.0444^{* * * *} \\
(0.0153)\end{array}$ & $\begin{array}{l}0.0564^{* *} \\
(0.0220)\end{array}$ & $\begin{array}{l}0.0621^{* *} \\
(0.0266)\end{array}$ & $\begin{array}{l}-0.0064 \\
(0.0299)\end{array}$ & $\begin{array}{l}0.0697^{\text {*** }} \\
(0.0216)\end{array}$ \\
\hline Age: $45-54$ & $\begin{array}{l}0.0299^{*} \\
(0.0175)\end{array}$ & $\begin{array}{l}0.0512^{*} \\
(0.0288)\end{array}$ & $\begin{array}{c}0.0281 \\
(0.0307)\end{array}$ & $\begin{array}{l}0.0286^{*} \\
(0.0150)\end{array}$ & $\begin{array}{l}0.1000^{* * *} \\
(0.0286)\end{array}$ & $\begin{array}{l}0.1189^{* * *} \\
(0.0306)\end{array}$ & $\begin{array}{l}0.0758^{* *} \\
(0.0319)\end{array}$ & $\begin{array}{c}0.0890^{* * *} \\
(0.0215)\end{array}$ \\
\hline Age: $55-64$ & $\begin{array}{l}0.0752^{\text {*** }} \\
(0.0171)\end{array}$ & $\begin{array}{c}0.0989^{* * *} \\
(0.0308)\end{array}$ & $\begin{array}{l}0.0843^{* *} \\
(0.0333)\end{array}$ & $\begin{array}{c}0.0462^{* * *} \\
(0.0164)\end{array}$ & $\begin{array}{c}0.1749^{* * *} \\
(0.0255)\end{array}$ & $\begin{array}{l}0.1406^{* * *} \\
(0.0268)\end{array}$ & $\begin{array}{l}0.1826^{* * *} \\
(0.0329)\end{array}$ & $\begin{array}{c}0.1332^{* * *} \\
(0.0229)\end{array}$ \\
\hline Age: $65-74$ & $\begin{array}{c}0.0622^{\text {*** }} \\
(0.0147)\end{array}$ & $\begin{array}{l}0.0764^{* *} \\
(0.0309)\end{array}$ & $\begin{array}{c}0.1333^{* * *} \\
(0.0352)\end{array}$ & $\begin{array}{l}0.0514^{* * *} \\
(0.0167)\end{array}$ & $\begin{array}{c}0.1899^{* * *} \\
(0.0288)\end{array}$ & $\begin{array}{l}0.1804^{* * *} \\
(0.0257)\end{array}$ & $\begin{array}{l}0.2554^{* * *} \\
(0.0351)\end{array}$ & $\begin{array}{l}0.1454^{* * *} \\
(0.0253)\end{array}$ \\
\hline Age: $75+$ & $\begin{array}{c}0.0973^{\text {*** }} \\
(0.0253)\end{array}$ & $\begin{array}{l}0.0664^{*} \\
(0.0360)\end{array}$ & $\begin{array}{c}0.1762^{* * *} \\
(0.0424)\end{array}$ & $\begin{array}{c}0.0705^{\text {**** }} \\
(0.0223)\end{array}$ & $\begin{array}{c}0.1663^{* * *} \\
(0.0336)\end{array}$ & $\begin{array}{c}0.1597^{* * *} \\
(0.0318)\end{array}$ & $\begin{array}{c}0.2364^{* * *} \\
(0.0378)\end{array}$ & $\begin{array}{c}0.2053^{\text {**** }} \\
(0.0252)\end{array}$ \\
\hline
\end{tabular}

Observations

$6,024 \quad 6,134$

6,141

6,141

5,985

6,107

6,111

6,120

Note: Standard errors clustered at the Agegroup-State level in parentheses, ${ }^{*} p<0.1,{ }^{* * *} p<0.05,{ }^{* * *} p<0.01$. All specifications also include controls for the individual's age, gender, marital status, education, city size, and whether the individual lives in the inner city. The omitted age category is 18-24 year olds. All regressions use sampling weights, and also include state fixed effects and year dummies. 


\section{Appendix Table 2. The Impact of Perceived Personal and National Economic Conditions on Attitudes towards Foreigners regarding their Rights and Attitudes towards Foreigners Regarding Marriage and Family}

\begin{tabular}{|c|c|c|c|c|c|c|}
\hline & \multicolumn{2}{|c|}{$\begin{array}{ll}1) & (2)\end{array}$} & (3) & (4) & (5) & (6) \\
\hline & \multicolumn{2}{|c|}{$\begin{array}{c}\text { Foreigners living in Germany } \\
\text { Should... }\end{array}$} & \multirow{2}{*}{$\begin{array}{c}\text { Jewish } \\
\text { people living } \\
\text { in Germany } \\
\text { should not } \\
\text { have the } \\
\text { same rights } \\
\text { as Germans }\end{array}$} & \multirow{2}{*}{$\begin{array}{c}\text { Ethnic } \\
\text { Germans from } \\
\text { Eastern Europe } \\
\text { living in } \\
\text { Germany } \\
\text { should not } \\
\text { have the same } \\
\text { rights as }\end{array}$} & \multirow{2}{*}{$\begin{array}{l}\text { Turkish } \\
\text { people } \\
\text { living in } \\
\text { Germany } \\
\text { should not } \\
\text { have the } \\
\text { same rights } \\
\text { as Germans }\end{array}$} & \multirow{2}{*}{$\begin{array}{l}\text { Italians living } \\
\text { in Germany } \\
\text { should not } \\
\text { have the } \\
\text { same rights } \\
\text { as Germans }\end{array}$} \\
\hline & $\begin{array}{c}\text {...marry } \\
\text { only people } \\
\text { of their own }\end{array}$ & $\begin{array}{l}\text {...not be } \\
\text { allowed to } \\
\text { take part in }\end{array}$ & & & & \\
\hline $\begin{array}{l}\text { Good Personal } \\
\text { Economic Conditions }\end{array}$ & $\begin{array}{c}-0.0196^{* * *} \\
(0.0076)\end{array}$ & $\begin{array}{l}-0.0239^{* * *} \\
(0.0068)\end{array}$ & $\begin{array}{l}-0.0439^{* * * * *} \\
(0.0134)\end{array}$ & $\begin{array}{l}-0.0151 \\
(0.0124)\end{array}$ & $\begin{array}{l}-0.0558^{* * * *} \\
(0.0140)\end{array}$ & $\begin{array}{l}-0.0287^{\text {** }} \\
(0.0135)\end{array}$ \\
\hline $\begin{array}{l}\text { Bad Personal } \\
\text { Economic Conditions }\end{array}$ & $\begin{array}{c}0.0187 \\
(0.0118)\end{array}$ & $\begin{array}{l}0.0322^{* * * *} \\
(0.0102)\end{array}$ & $\begin{array}{l}0.0539^{* * *} \\
(0.0201)\end{array}$ & $\begin{array}{l}0.0487^{*} \\
(0.0252)\end{array}$ & $\begin{array}{c}0.0344 \\
(0.0220)\end{array}$ & $\begin{array}{c}0.0389 \\
(0.0118)\end{array}$ \\
\hline $\begin{array}{l}\text { Good National } \\
\text { Economic Conditions }\end{array}$ & $\begin{array}{l}-0.0067 \\
(0.0083)\end{array}$ & $\begin{array}{l}-0.0148 \\
(0.0094)\end{array}$ & $\begin{array}{l}0.0336^{*} \\
(0.0169)\end{array}$ & $\begin{array}{l}-0.0158 \\
(0.0179)\end{array}$ & $\begin{array}{c}0.0256 \\
(0.0205)\end{array}$ & $\begin{array}{c}0.0138 \\
(0.0169)\end{array}$ \\
\hline $\begin{array}{l}\text { Bad National } \\
\text { Economic Conditions }\end{array}$ & $\begin{array}{l}0.0286^{* * *} \\
(0.0068)\end{array}$ & $\begin{array}{l}0.0525^{* * *} \\
(0.0093)\end{array}$ & $\begin{array}{l}0.0480^{\text {**** }} \\
(0.0125)\end{array}$ & $\begin{array}{l}0.0670^{* * *} \\
(0.0129)\end{array}$ & $\begin{array}{l}0.0614^{\text {**** }} \\
(0.0113)\end{array}$ & $\begin{array}{l}0.0488^{* * *} \\
(0.0145)\end{array}$ \\
\hline Observations & 13,090 & 13,051 & 5,886 & 6,080 & 6,070 & 6,075 \\
\hline
\end{tabular}

Good Personal

Econ Conditions

Bad Personal

Econ Conditions

Good National

Econ Conditions

Bad National

Econ Conditions
(2)

(3)

(4)

It would be unpleasant to have neighbor who is

\begin{tabular}{ccc}
\hline & Ethnic & \\
Jewish & German \\
from & Turkish Italian
\end{tabular}

$-0.0271^{* * * *}-0.0400^{* * *}-0.0354^{* *}-0.0144^{*}$

$\begin{array}{llll}(0.0090) & (0.0138) & (0.0147) & (0.0076)\end{array}$

0.0171

$-0.0231$

$(0.0151)$

(0.0195)

0.0078

(0.0239)

$-0.0044$

0.0111

$-0.0180$

$-0.0357$

(0.0110)

$(0.0151)$

(0.0195)

(0.0239)

$-0.0042$

$0.0384^{* * * *}$

$0.0499^{* * *}$

(0.0111)
(5)

(6)

(7)

(8)

It would be unpleasant if a ... person married into the family

\section{Ethnic}

Jewish German from Turkish Italian

Eastern

Europe

$\begin{array}{llll}-0.0150 & -0.0259^{* *} & -0.0066 & -0.0225^{* *}\end{array}$

$\begin{array}{llll}(0.0139) & (0.0130) & (0.0156) & (0.0108)\end{array}$

$\begin{array}{llll}0.0100 & 0.0093 & -0.0249 & 0.0228\end{array}$

$\begin{array}{lll}(0.0196) & (0.0192) \quad(0.0208)\end{array}$

(0.0152)

$0.0131-0.0219-0.0398^{* *}-0.0065$

$\begin{array}{llll}(0.0196) & (0.0192) & (0.0208) & (0.0151)\end{array}$

$0.0408^{* * *} \quad 0.0558^{* * *} \quad 0.0542^{* * *} \quad 0.0186^{*}$

$\begin{array}{lll}(0.0153) & (0.0126) \quad(0.0154)\end{array}$

(0.0106) 


\section{Appendix Table 3A. The Impact of Perceived Personal Economic Conditions on Attitudes towards Foreigners regarding their Rights, Controlling for Household Income}

(1)

Foreigners living in Germany

Should...

\begin{tabular}{cc}
\hline ...marry & ...not be \\
only people & allowed to \\
of their own & take part in \\
nationality & any political \\
& activity
\end{tabular}

(3)

Jewish
people living
in Germany
should not
have the
same rights
as Germans

(4)

Ethnic

Germans from

Eastern Europe

living in

Germany

should not

have the same

rights as

Germans
(5)

(6)

Turkish Italians living people in Germany living in should not Germany have the should not same rights have the as Germans same rights as Germans
Good Personal

Economic Conditions

Bad Personal

Economic Conditions

Household Income

Catholic

Other religion or

Not religious

\begin{tabular}{lll}
\hline & Panel A \\
\hline$-0.0224^{* * * *}$ & $-0.0227^{* * *}$ & $-0.0499^{* * * *}$
\end{tabular}

(0.0080)

$0.0221^{*}$

(0.0124)

$-0.0104^{* *}$

(0.0050)

$-0.0052$

(0.0123)

$-0.0111$

(0.0084)
(0.0066)

$0.0344^{* * *}$

(0.0119)

$-0.0121^{\text {**** }}$

(0.0025)

$-0.0080$

(0.0130)

$-0.0209^{*}$

(0.0114)
(0.0148)

$0.0644^{* * *}$

(0.0203)

$-0.0085$

$(0.0061)$

0.0133

(0.0206)

$-0.0352^{* * * *}$

(0.0124)

$0.0657^{\text {** }}$

(0.0264)

$-0.0017$

(0.0074)

$-0.0022$

(0.0162)

$-0.0373^{* * *}$

(0.0153)
$-0.0219$

(0.0176) $-0.0671^{\text {* }}$

(0.0147)

$0.0558^{* *}$

(0.0249)

$-0.0026$

(0.0088)

0.0180

(0.0202)

$-0.0376^{*}$

(0.0210)
$-0.0288$

(0.0158)

$0.0521^{* * *}$

(0.0238)

$-0.0058$

(0.0078)

$-0.0095$

(0.0196)

(0.0420**

$-0.0420^{\text {*** }}$

(0.0190)

\begin{tabular}{lcccccc}
\hline Observations & 10,573 & 10,538 & 4,711 & 4,846 & 4,838 & 4,846 \\
\cline { 2 - 6 } Good Personal & \multicolumn{7}{c}{ Panel B } & \multicolumn{3}{c}{ B } \\
\cline { 2 - 6 } Economic Conditions & $\left(0.0200^{* *}\right.$ & $-0.0214^{* * *}$ & $-0.0477^{* * *}$ & $-0.0327^{* *}$ & $-0.0665^{* * *}$ & -0.0260 \\
Bad Personal & $(0.0070)$ & $(0.0155)$ & $(0.0132)$ & $(0.0158)$ & $(0.0166)$ \\
Economic Conditions & $\left(0.0244^{*}\right.$ & $0.0355^{* * *}$ & $0.0640^{* * *}$ & $0.0656^{* *}$ & $0.0500^{* *}$ & $0.0523^{* *}$ \\
Foreign Contact at & $-0.0297^{* * *}$ & $(0.0132)$ & $(0.0205)$ & $(0.0262)$ & $(0.0243)$ & $(0.0247)$ \\
Work & $-0.0527^{* * *}$ & -0.0127 & -0.0143 & -0.0298 & -0.0003 \\
Household Income & $(0.0093)$ & $(0.0093)$ & $(0.0146)$ & $(0.0167)$ & $(0.0186)$ & $(0.0195)$ \\
& $-0.0098^{*}$ & $-0.0114^{* * *}$ & -0.0082 & -0.0018 & -0.0032 & -0.0066 \\
Catholic & $(0.0049)$ & $(0.0026)$ & $(0.0061)$ & $(0.0073)$ & $(0.0086)$ & $(0.0078)$ \\
& -0.0029 & -0.0072 & 0.0128 & 0.0019 & 0.0201 & -0.0041 \\
Other religion or & $(0.0116)$ & $(0.0131)$ & $(0.0200)$ & $(0.0160)$ & $(0.0203)$ & $(0.0193)$ \\
Not religious & -0.0085 & -0.0187 & $-0.0341^{* *}$ & -0.0182 & $-0.0364^{*}$ & $-0.0410^{* *}$ \\
\hline Observations & $(0.0085)$ & $(0.0116)$ & $(0.0158)$ & $(0.0181)$ & $(0.0217)$ & $(0.0190)$ \\
\hline
\end{tabular}

Table continued on following page 
Appendix Table 3A (concluded)

\begin{tabular}{|c|c|c|c|c|c|c|}
\hline \multirow{3}{*}{ 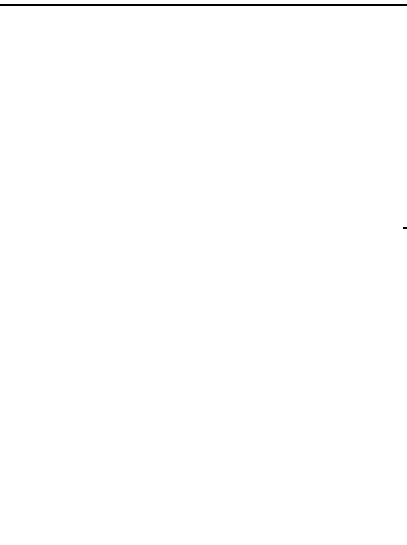 } & & & \multirow{3}{*}{$\begin{array}{c}\text { (3) } \\
\text { Jewish } \\
\text { people living } \\
\text { in Germany } \\
\text { should not } \\
\text { have the } \\
\text { same rights } \\
\text { as Germans }\end{array}$} & \multirow{3}{*}{$\begin{array}{c}(4) \\
\text { Ethnic } \\
\text { Germans from } \\
\text { Eastern Europe } \\
\text { living in } \\
\text { Germany } \\
\text { should not } \\
\text { have the same } \\
\text { rights as } \\
\text { Germans }\end{array}$} & \multirow{3}{*}{$\begin{array}{c}\text { (5) } \\
\text { Turkish } \\
\text { people } \\
\text { living in } \\
\text { Germany } \\
\text { should not } \\
\text { have the } \\
\text { same rights } \\
\text { as Germans }\end{array}$} & \multirow{3}{*}{$\begin{array}{c}\text { (6) } \\
\text { Italians living } \\
\text { in Germany } \\
\text { should not } \\
\text { have the } \\
\text { same rights } \\
\text { as Germans }\end{array}$} \\
\hline & Sho & $\begin{array}{l}\text { ig in Germany } \\
\text { ld... }\end{array}$ & & & & \\
\hline & $\begin{array}{c}\text {...marry } \\
\text { only people } \\
\text { of their own } \\
\text { nationality }\end{array}$ & $\begin{array}{l}\text {...not be } \\
\text { allowed to } \\
\text { take part in } \\
\text { any political } \\
\text { activity }\end{array}$ & & & & \\
\hline \multirow[b]{2}{*}{$\begin{array}{l}\text { Good Personal } \\
\text { Economic Conditions }\end{array}$} & \multicolumn{6}{|c|}{ Panel C } \\
\hline & $\begin{array}{l}-0.0198^{* *} \\
(0.0087)\end{array}$ & $\begin{array}{l}-0.0266^{* * * *} \\
(0.0094)\end{array}$ & $\begin{array}{c}-0.0489^{* * * *} \\
(0.0153)\end{array}$ & $\begin{array}{c}-0.0335^{* *} \\
(0.0133)\end{array}$ & $\begin{array}{l}-0.0671^{* * * * *} \\
(0.0159)\end{array}$ & $\begin{array}{l}-0.0261 \\
(0.0166)\end{array}$ \\
\hline $\begin{array}{l}\text { Bad Personal } \\
\text { Economic Conditions }\end{array}$ & $\begin{array}{l}0.0249^{*} \\
(0.0129)\end{array}$ & $\begin{array}{l}0.0353^{* *} \\
(0.0150)\end{array}$ & $\begin{array}{l}0.0614^{* * *} \\
(0.0202)\end{array}$ & $\begin{array}{l}0.0652^{* *} \\
(0.0260)\end{array}$ & $\begin{array}{l}0.0492^{* *} \\
(0.0241)\end{array}$ & $\begin{array}{l}0.0512^{* *} \\
(0.0243)\end{array}$ \\
\hline $\begin{array}{l}\text { Foreign Contact at } \\
\text { Work }\end{array}$ & $\begin{array}{c}-0.0276^{* * *} \\
(0.0103)\end{array}$ & $\begin{array}{c}-0.0457^{* * * *} \\
(0.0117)\end{array}$ & $\begin{array}{l}-0.0080 \\
(0.0146)\end{array}$ & $\begin{array}{l}-0.0099 \\
(0.0174)\end{array}$ & $\begin{array}{l}-0.0253 \\
(0.0192)\end{array}$ & $\begin{array}{c}0.0013 \\
(0.0197)\end{array}$ \\
\hline $\begin{array}{l}\text { Foreign Contact in } \\
\text { Family }\end{array}$ & $\begin{array}{c}-0.0473^{* * *} \\
(0.0110)\end{array}$ & $\begin{array}{l}-0.0493^{* * *} \\
(0.0133)\end{array}$ & $\begin{array}{l}-0.0466^{* *} \\
(0.0195)\end{array}$ & $\begin{array}{l}-0.0856^{* * *} \\
(0.0191)\end{array}$ & $\begin{array}{l}-0.0727^{* * *} \\
(0.0208)\end{array}$ & $\begin{array}{l}-0.0463^{* *} \\
(0.0179)\end{array}$ \\
\hline Nazi State in 1928 & $\begin{array}{l}-0.0033 \\
(0.0141)\end{array}$ & $\begin{array}{l}-0.0005 \\
(0.0173)\end{array}$ & $\begin{array}{l}0.0712^{* * *} \\
(0.0231)\end{array}$ & $\begin{array}{c}0.0173 \\
(0.0293)\end{array}$ & $\begin{array}{c}0.0220 \\
(0.0348)\end{array}$ & $\begin{array}{c}0.0394 \\
(0.0242)\end{array}$ \\
\hline Household Income & $\begin{array}{l}-0.0097^{*} \\
(0.0057)\end{array}$ & $\begin{array}{l}-0.0103^{* * *} \\
(0.0024)\end{array}$ & $\begin{array}{l}-0.0082 \\
(0.0061)\end{array}$ & $\begin{array}{l}-0.0016 \\
(0.0070)\end{array}$ & $\begin{array}{l}-0.0033 \\
(0.0083)\end{array}$ & $\begin{array}{l}-0.0063 \\
(0.0079)\end{array}$ \\
\hline Catholic & $\begin{array}{l}-0.0015 \\
(0.0120)\end{array}$ & $\begin{array}{l}-0.0014 \\
(0.0124)\end{array}$ & $\begin{array}{c}0.0136 \\
(0.0186)\end{array}$ & $\begin{array}{c}0.0055 \\
(0.0147)\end{array}$ & $\begin{array}{c}0.0200 \\
(0.0197)\end{array}$ & $\begin{array}{l}-0.0027 \\
(0.0178)\end{array}$ \\
\hline $\begin{array}{l}\text { Other religion or } \\
\text { Not religious }\end{array}$ & $\begin{array}{c}0.0036 \\
(0.0102)\end{array}$ & $\begin{array}{l}-0.0072 \\
(0.0115)\end{array}$ & $\begin{array}{l}-0.0314^{*} \\
(0.0160)\end{array}$ & $\begin{array}{l}-0.0138 \\
(0.0173)\end{array}$ & $\begin{array}{l}-0.0297 \\
(0.0216)\end{array}$ & $\begin{array}{l}-0.0368^{*} \\
(0.0189)\end{array}$ \\
\hline Observations & 8,253 & 8,226 & 4,592 & 4,717 & 4,709 & 4,717 \\
\hline
\end{tabular}




\section{Appendix Table 3B. The Impact of Perceived Personal Economic Conditions on Attitudes towards Foreigners Regarding Marriage and Family, Controlling for Household Income}

\begin{tabular}{|c|c|c|c|c|c|c|c|c|}
\hline & (1) & (2) & (3) & (4) & (5) & (6) & (7) & (8) \\
\hline & \multicolumn{4}{|c|}{$\begin{array}{l}\text { It would be unpleasant to have neighbor who } \\
\text { is }\end{array}$} & \multicolumn{4}{|c|}{$\begin{array}{l}\text { It would be unpleasant if a ... person married } \\
\text { into the family }\end{array}$} \\
\hline & Jewish & $\begin{array}{c}\text { Ethnic } \\
\text { German } \\
\text { from } \\
\text { Eastern }\end{array}$ & Turkish & Italian & Jewish & $\begin{array}{l}\text { Ethnic } \\
\text { German } \\
\text { om Eastern } \\
\text { Europe }\end{array}$ & Turkish & Italian \\
\hline $\begin{array}{l}\text { Sood Personal } \\
\text { Econ Conditions }\end{array}$ & $\begin{array}{c}-0.0305^{* *} \\
(0.0116)\end{array}$ & $\begin{array}{r}-0.0527^{* * *} \\
(0.0160)\end{array}$ & $\begin{array}{l}-0.0443^{* * * * *} \\
(0.0158)\end{array}$ & $\begin{array}{l}-0.01 \\
(0.00\end{array}$ & $\begin{array}{l}\mathrm{el} \mathrm{A} \\
-0.0145 \\
(0.0152)\end{array}$ & $\begin{array}{l}-0.0286^{*} \\
(0.0151)\end{array}$ & $\begin{array}{l}-0.0103 \\
(0.0171)\end{array}$ & $\begin{array}{l}-0.0137 \\
(0.0136)\end{array}$ \\
\hline $\begin{array}{l}\text { Bad Personal } \\
\text { Econ Conditions }\end{array}$ & $\begin{array}{c}0.0168 \\
(0.0156)\end{array}$ & $\begin{array}{l}-0.0079 \\
(0.0232)\end{array}$ & $\begin{array}{c}0.0237 \\
(0.0267)\end{array}$ & $\begin{array}{l}-0.0071 \\
(0.0117)\end{array}$ & $\begin{array}{l}-0.0064 \\
(0.0217)\end{array}$ & $\begin{array}{c}0.0187 \\
(0.0204)\end{array}$ & $\begin{array}{l}-0.0251 \\
(0.0245)\end{array}$ & $\begin{array}{c}0.0151 \\
(0.0168)\end{array}$ \\
\hline Household Income & $\begin{array}{l}-0.0060 \\
(0.0051)\end{array}$ & $\begin{array}{r}0.0110^{*} \\
(0.0063)\end{array}$ & $\begin{array}{c}0.0054 \\
(0.0075)\end{array}$ & $\begin{array}{c}0.0008 \\
(0.0029)\end{array}$ & & $\begin{array}{c}0.0009 \\
(0.0074)\end{array}$ & $\begin{array}{l}-0.0098 \\
(0.0074)\end{array}$ & $\begin{array}{c}-0.0147^{* * *} \\
(0.0048)\end{array}$ \\
\hline Catholic & & $\begin{array}{c}0.0011 \\
(0.0169)\end{array}$ & $\begin{array}{c}0.0412^{*} \\
(0.0213)\end{array}$ & $\begin{array}{l}-0.0012 \\
(0.0089)\end{array}$ & & $\begin{array}{c}0.0198 \\
(0.0205)\end{array}$ & & $\begin{array}{c}0.0219 \\
(0.0153)\end{array}$ \\
\hline $\begin{array}{l}\text { Other religion or } \\
\text { Not religious }\end{array}$ & & $\begin{array}{c}0.0159 \\
(0.0140)\end{array}$ & $\begin{array}{l}-0.0022 \\
(0.0181)\end{array}$ & $\begin{array}{c}0.0008 \\
(0.0098)\end{array}$ & & $\begin{array}{c}-0.0022 \\
(0.0205)\end{array}$ & $\begin{array}{c}-0.0580^{* * * *} \\
(0.0202)\end{array}$ & $\begin{array}{l}-0.0063 \\
(0.0123)\end{array}$ \\
\hline observ & 4,784 & 4,865 & 4,872 & 4,871 & 4,755 & 4,850 & 4,852 & 4,855 \\
\hline $\begin{array}{l}\text { Good Personal } \\
\text { Econ Conditions }\end{array}$ & & & $\begin{array}{l}{ }^{*}-0.0502^{* * * 1} \\
(0.0157)\end{array}$ & $\begin{array}{l}-0.01 \\
(0.00\end{array}$ & $\begin{array}{l}\mathrm{el} \mathrm{B} \\
-0.0156 \\
(0.0158)\end{array}$ & $\begin{array}{c}-0.0327^{* *} \\
(0.0149)\end{array}$ & & \\
\hline $\begin{array}{l}\text { Bad Personal } \\
\text { Econ Conditions }\end{array}$ & $\begin{array}{c}0.0153 \\
(0.0160)\end{array}$ & $\begin{array}{l}-0.0109 \\
(0.0232)\end{array}$ & $\begin{array}{c}0.0196 \\
(0.0264)\end{array}$ & $\begin{array}{l}-0.0070 \\
(0.0120)\end{array}$ & $\begin{array}{l}-0.0115 \\
(0.0218)\end{array}$ & $\begin{array}{l}0.0161 \\
(0.0210)\end{array}$ & $\begin{array}{l}-0.0315 \\
(0.0243)\end{array}$ & $\begin{array}{c}0.0111 \\
(0.0177)\end{array}$ \\
\hline $\begin{array}{l}\text { Foreign Contact at } \\
\text { Work }\end{array}$ & $\begin{array}{l}-0.0272^{* *} \\
(0.0117)\end{array}$ & $\begin{array}{l}-0.0269 \\
(0.0166)\end{array}$ & $\begin{array}{r}-0.0507^{* * * *} \\
(0.0164)\end{array}$ & $\begin{array}{c}* 0.0275^{* * * *} \\
(0.0080)\end{array}$ & $\begin{array}{c}-0.0614^{* * * *} \\
(0.0151)\end{array}$ & $\begin{array}{c}-0.0418^{* * *} \\
(0.0162)\end{array}$ & $\begin{array}{c}-0.0770^{* * * *} \\
(0.0157)\end{array}$ & $\begin{array}{c}-0.0270^{* * *} \\
(0.0112)\end{array}$ \\
\hline Household Income & $\begin{array}{c}-0.0062 \\
(0.0050)\end{array}$ & $\begin{array}{c}0.0113^{*} \\
(0.0063)\end{array}$ & $\begin{array}{c}0.0057 \\
(0.0076)\end{array}$ & $\begin{array}{c}0.0014 \\
(0.0030)\end{array}$ & $\begin{array}{c}-0.0098 \\
(0.0067)\end{array}$ & $\begin{array}{c}0.0021 \\
(0.0073)\end{array}$ & $\begin{array}{l}-0.0089 \\
(0.0072)\end{array}$ & $\begin{array}{c}-0.0142^{* * *} \\
(0.0047)\end{array}$ \\
\hline Catholic & $\begin{array}{c}0.0001 \\
(0.0158)\end{array}$ & $\begin{array}{c}0.0049 \\
(0.0177)\end{array}$ & $\begin{array}{c}0.0428^{*} \\
(0.0222)\end{array}$ & $\begin{array}{c}0.0005 \\
(0.0087)\end{array}$ & $\begin{array}{c}0.0372 \\
(0.0255)\end{array}$ & $\begin{array}{c}0.0253 \\
(0.0211)\end{array}$ & $\begin{array}{c}0.0235 \\
(0.0208)\end{array}$ & $\begin{array}{c}0.0237 \\
(0.0155)\end{array}$ \\
\hline $\begin{array}{l}\text { Other religi } \\
\text { Not religiol }\end{array}$ & $\begin{array}{c}0.0164 \\
(0.0133)\end{array}$ & $\begin{array}{c}0.0185 \\
(0.0137)\end{array}$ & $\begin{array}{c}0.0005 \\
(0.0173)\end{array}$ & $\begin{array}{c}0.0030 \\
(0.0099)\end{array}$ & $\begin{array}{l}-0.0033 \\
(0.0171)\end{array}$ & $\begin{array}{l}-0.0010 \\
(0.0214)\end{array}$ & $\begin{array}{c}-0.0533^{* * *} \\
(0.0202)\end{array}$ & $\begin{array}{l}-0.0044 \\
(0.0124)\end{array}$ \\
\hline Observations & 4,657 & 4,733 & 4,739 & 4,738 & 4,629 & 4,717 & 4,720 & 4,722 \\
\hline
\end{tabular}


Appendix Table 3B (concluded)

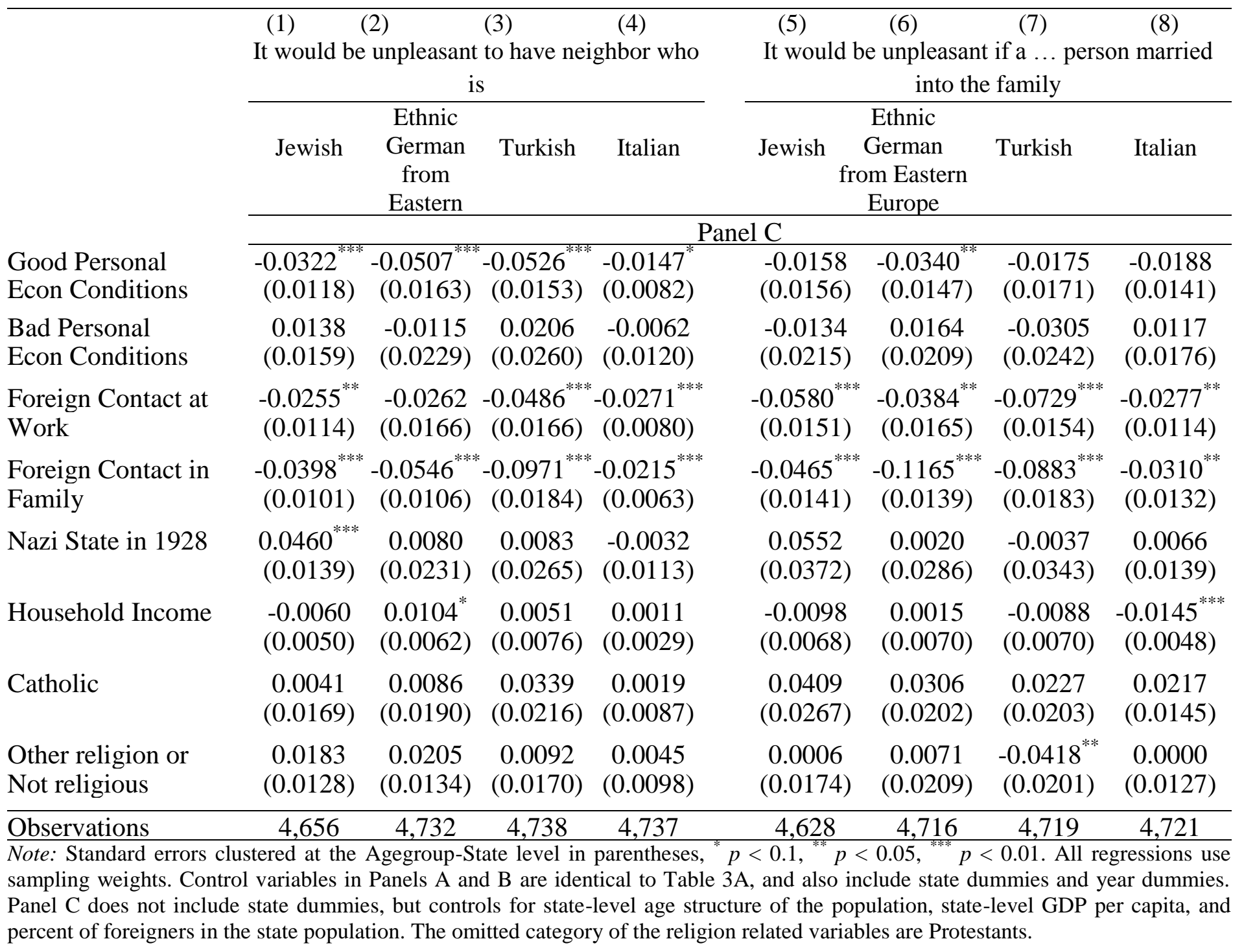




\section{Appendix Table 4. Descriptive Statistics of Outcome Variables by Gender}

\begin{tabular}{|c|c|c|c|c|c|c|}
\hline \multirow[b]{2}{*}{ Variable } & \multicolumn{3}{|c|}{ Females } & \multicolumn{3}{|c|}{ Males } \\
\hline & Mean & Std. Dev. & $\mathrm{N}$ & Mean & Std. Dev. & $\mathrm{N}$ \\
\hline Foreigners Should Marry Their Own & 0.196 & 0.397 & 6,716 & 0.163 & 0.369 & 6,430 \\
\hline No Politics for Foreigners & 0.293 & 0.455 & 6,670 & 0.272 & 0.445 & 6,432 \\
\hline No equal rights for Jews & 0.218 & 0.413 & 3,012 & 0.231 & 0.421 & 2,893 \\
\hline No equal rights for Aussiedler & 0.288 & 0.453 & 3,122 & 0.276 & 0.447 & 2,978 \\
\hline No equal rights for Turks & 0.451 & 0.498 & 3,118 & 0.449 & 0.497 & 2,972 \\
\hline No equal rights for Italians & 0.254 & 0.435 & 3,118 & 0.268 & 0.443 & 2,978 \\
\hline Unpleasant Neighbor - Jewish & 0.119 & 0.323 & 3,076 & 0.126 & 0.331 & 2,948 \\
\hline Unpleasant Neighbor - Aussiedler & 0.220 & 0.414 & 3,137 & 0.235 & 0.424 & 2,997 \\
\hline Unpleasant Neighbor - Turkish & 0.397 & 0.489 & 3,143 & 0.388 & 0.487 & 2,998 \\
\hline Unpleasant Neighbor - Italian & 0.071 & 0.256 & 3,148 & 0.077 & 0.266 & 2,993 \\
\hline Unpleasant Marriage - Jewish & 0.255 & 0.436 & 3,061 & 0.261 & 0.439 & 2,924 \\
\hline Unpleasant Marriage - Aussiedler & 0.305 & 0.460 & 3,132 & 0.309 & 0.462 & 2,975 \\
\hline Unpleasant Marriage - Turkish & 0.553 & 0.497 & 3,137 & 0.555 & 0.497 & 2,974 \\
\hline Unpleasant Marriage - Italian & 0.167 & 0.373 & 3,143 & 0.185 & 0.388 & 2,977 \\
\hline Intense Dislike of Foreigners & 0.113 & 0.316 & 6,631 & 0.096 & 0.295 & 6,398 \\
\hline Intense Dislike of Equal Rights & 0.063 & 0.242 & 2,986 & 0.066 & 0.248 & 2,878 \\
\hline Intense Dislike of Intermarriage & 0.055 & 0.228 & 3,046 & 0.044 & 0.205 & 2,908 \\
\hline
\end{tabular}




\section{Appendix Table 5A. The Impact of Perceived Personal Economic Conditions on Attitudes towards Foreigners regarding their Rights: Males Only}

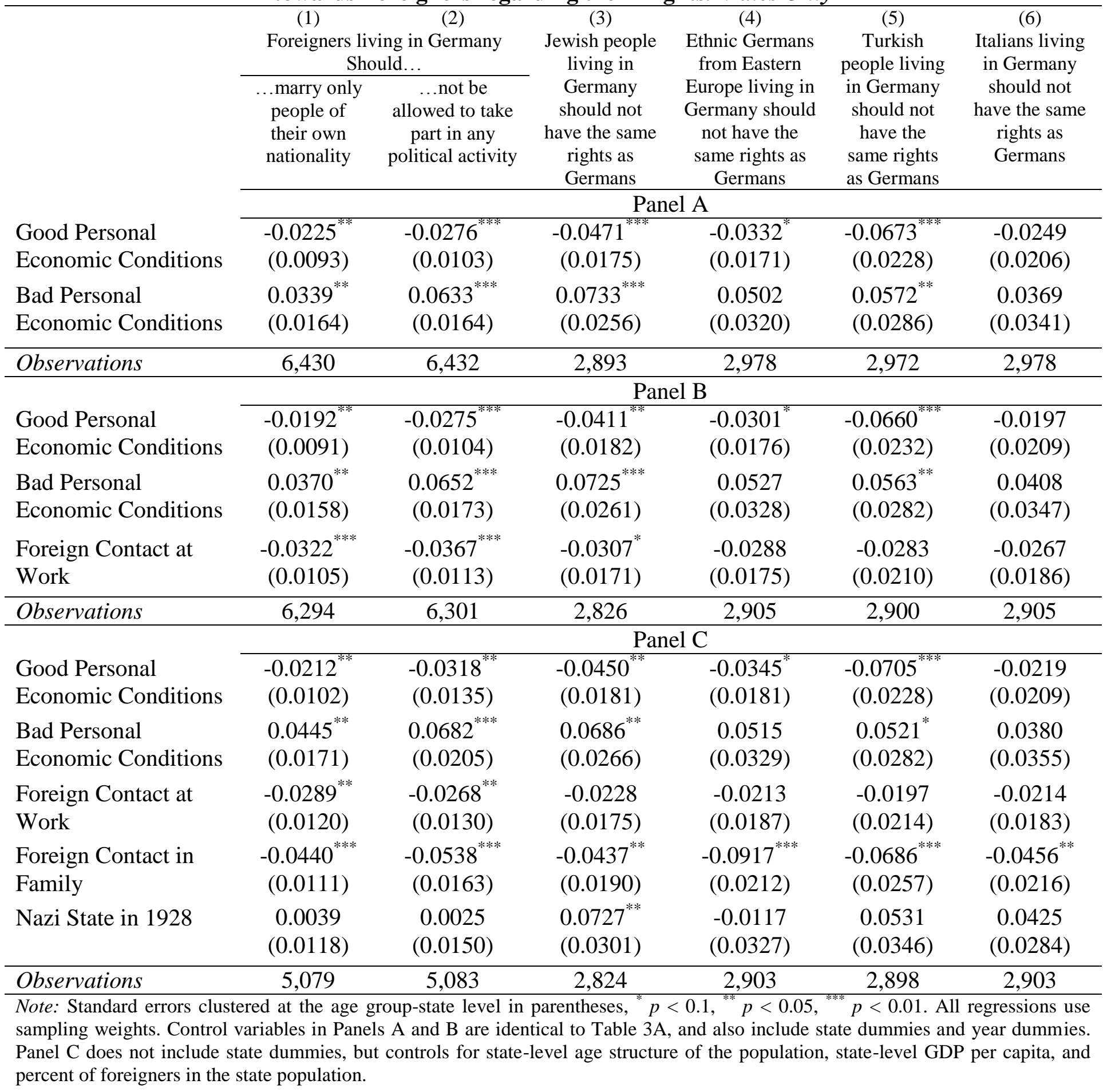




\section{Appendix Table 5B. The Impact of Perceived Personal Economic Conditions on Attitudes} towards Foreigners Regarding Marriage and Family: Males Only

\section{(1) \\ (2) \\ (3)}

It would be unpleasant to have neighbor who is

\begin{tabular}{cccc}
\hline & Ethnic & & \\
\multirow{3}{*}{ Jewish } & German & & \\
& from & Turkish Italian \\
& Eastern & & \\
& Europe & \\
\hline
\end{tabular}

Good Personal

$-0.0451^{* * * *}-0.0617^{* * * *}-0.0734^{* * *}-0.0344^{* * * *}$

$\begin{array}{llll}(0.0140) & (0.0211) & (0.0176) & (0.0112)\end{array}$

$\begin{array}{llll}0.0351^{*} & -0.0051 & 0.0116 & -0.0019\end{array}$

(0.0207)

Econ Conditions

Bad Personal

Econ Conditions

$\begin{array}{lll}(0.0293) & (0.0281) & (0.0158)\end{array}$

(5)

It would be unpleasant if a ... person married into the family

$\begin{array}{cccc} & \text { Ethnic } & & \\ \text { Jewish } & \text { German from } & \text { Turkish } & \text { Italian } \\ & \text { Eastern } \\ & \text { Europe } & & \end{array}$

Panel A

$\begin{array}{llll}2,948 & 2,997 & 2,998 & 2,993\end{array}$

$-0.0113$

$(0.0173)$

$-0.0388^{*}$

$-0.0429^{* * *}-0.0360^{* * *}$

0.0351

$(0.0200)$

(0.0185)

(0.0148)

Observations

Good Personal

2,948

2,997

(0.0278)

0.0261

$-0.0134$

0.0323

$\begin{array}{llll}2,924 & 2,975 & 2,974 & 2,977\end{array}$

Econ Conditions

\begin{tabular}{cccc}
\hline$-0.0439^{* * * *}$ & $-0.0593^{* * * *}-0.0747^{* * * *}-0.0319^{* * * *}$ \\
$(0.0140)$ & $(0.0215)$ & $(0.0176)$ & $(0.0101)$
\end{tabular}

\section{Panel B}

Bad Personal

$\begin{array}{lllll}0.0373^{*} & -0.0078 & 0.0070 & -0.0014\end{array}$

$\begin{array}{llll}0.0215) & (0.0299) & (0.0282) & (0.0167)\end{array}$

$-0.0099$

$(0.0170)$

$\begin{array}{lll}-0.0401^{*} & -0.0432^{* *} & -0.0355^{* *} \\ (0.0204) & (0.0183) & (0.0151)\end{array}$

Econ Conditions

$$
-0.0308^{* *}-0.0277-0.0546^{* *}-0.0289^{* *}
$$

0.0305

$(0.0204)$

$(0.0183)$

(0.0151)

Foreign Contact at

$\begin{array}{llll}(0.0135) & (0.0219) & (0.0209) & (0.0113)\end{array}$

$(0.0272)$

$(0.0303)$

$\begin{array}{ll}-0.0134 & 0.0341\end{array}$

$(0.0324) \quad(0.0207)$

Work

2,878

\begin{tabular}{ccccc}
2,878 & 2,921 & 2,923 & 2,918 & 2, \\
& & Panel C \\
\hline$-0.0448^{* * *}$ & $-0.0623^{* * *}-0.0800^{* * *}-0.0315^{* * *}$ & -0.010
\end{tabular}

$-0.0679^{* * * *}$

$-0.0462^{* *}-$

Observations

Good Personal

(0.0173)

$\begin{array}{lll}(0.0215) & (0.0188) & (0.0128)\end{array}$

Econ Conditions

\begin{tabular}{ccc}
\hline$-0.0448^{* * * *}$ & $-0.0623^{* * * *}-0.0800^{* * * *}-0.0315^{\text {*** }}$ \\
$(0.0138)$ & $(0.0207)(0.0169)$ & $(0.0101)$
\end{tabular}

$-0.0113$

2,900

$(0.0166)$

$\begin{array}{ccc}-0.0429^{* * *} & -0.0476^{* * *} & -0.0 \\ (0.0206) & (0.0181) & (0.0 \\ 0.0243 & -0.0144 & 0.0\end{array}$

2,899

0.0259

0.0243

$-0.0144$

$(0.0320)$

0.0338

$\begin{array}{cccc}0.0355 & -0.0093 & 0.0076 & 0.0010 \\ (0.0215) & (0.0298) & (0.0284) & (0.0166)\end{array}$

(0.0271)

$(0.0306)$

$-0.0614^{* * *}-0.0362$

$-0.0328^{*}$

(0.0208)

Foreign Contact at $-0.0227-0.0231-0.0502^{* *}-0.0272^{* * *}$

(0.0172)

$(0.0222)$

(0.0185)

$-0.0370^{* * * *}$

$\begin{array}{lllll}(0.0142) & (0.0226) & (0.0215) & (0.0113)\end{array}$

Foreign Contact in $-0.0598^{* * * *}-0.0612^{* * * *}-0.0886^{* * * *}-0.0170^{* * *}$ $-0.0426^{* * *}-0.1273^{* * *}-0.1022^{* * * *}-0.0523^{* * * *}$

Family

Nazi State in 1928

$$
\begin{array}{llll}
(0.0135) & (0.0198) & (0.0241) & (0.0085)
\end{array}
$$

(0.0173)

(0.0236)

$(0.0231)$

$(0.0163)$

$\begin{array}{llll}0.0501^{* * *} & -0.0138 & -0.0062 & 0.0070\end{array}$

0.0520

$-0.0429$

0.0072

$-0.0048$

$\begin{array}{llll}(0.0198) & (0.0329) & (0.0246) & (0.0165)\end{array}$

$(0.0371)$

$(0.0341)$

$(0.0408)$

$(0.0202)$

Observations

2,876

$2,919 \quad 2,921$

2,916

2,853

2,898

2,897

2,900

Note: Standard errors clustered at the age group-State level in parentheses, ${ }^{*} p<0.1,{ }^{* *} p<0.05,{ }^{* * *} p<0.01$. All regressions use sampling weights. Control variables in Panels A and B are identical to Table 3A, and also include state dummies and year dummies. Panel C does not include state dummies, but controls for state-level age structure of the population, state-level GDP per capita, and percent of foreigners in the state population 


\section{Appendix Table 6A. The Impact of Perceived Personal Economic Conditions on Attitudes towards Foreigners regarding their Rights: Females Only}

(1)

Foreigners living in Germany Should..

$\begin{array}{cc}\text {...marry only } & \text {...not be } \\ \text { people of } & \text { allowed to take } \\ \text { their own } & \text { part in any } \\ \text { nationality } & \text { political activity }\end{array}$

(3)

Jewish people living in Germany should not have the same rights as Germans
(4)

Ethnic Germans from Eastern

Europe living in

Germany should not have the same rights as
(5)

Turkish people living in Germany should not have the same rights as Germans
(6)

Italians living in Germany should not have the same rights as Germans

\begin{tabular}{|c|c|c|c|c|c|c|}
\hline \multirow{3}{*}{$\begin{array}{l}\text { Good Personal } \\
\text { Economic Conditions }\end{array}$} & \multicolumn{6}{|c|}{ Panel A } \\
\hline & $-0.0314^{* * * *}$ & $-0.0478^{* * *}$ & $-0.0497^{* * *}$ & -0.0305 & $-0.0661^{* * *}$ & -0.0277 \\
\hline & $(0.0096)$ & $(0.0104)$ & $(0.0173)$ & $(0.0196)$ & $(0.0176)$ & $(0.0179)$ \\
\hline Bad Personal & 0.0149 & $0.0326^{* *}$ & $0.0571^{* *}$ & $0.0804^{* * *}$ & 0.0393 & $0.0614^{* *}$ \\
\hline Economic Conditions & $(0.0174)$ & $(0.0145)$ & $(0.0249)$ & $(0.0291)$ & $(0.0263)$ & $(0.0251)$ \\
\hline \multirow[t]{2}{*}{ Observations } & 6,716 & 6,670 & 3,012 & 3,122 & 3,118 & 3,118 \\
\hline & \multicolumn{6}{|c|}{ Panel B } \\
\hline Good Personal & $-0.0285^{* * *}$ & $-0.0429^{* * * *}$ & $-0.0467^{\text {*** }}$ & -0.0291 & $-0.0620^{* * * *}$ & -0.0228 \\
\hline Economic Conditions & $(0.0096)$ & $(0.0107)$ & $(0.0182)$ & $(0.0201)$ & $(0.0188)$ & $(0.0177)$ \\
\hline Bad Personal & 0.0176 & $0.0327^{* *}$ & $0.0594^{* *}$ & $0.0771^{* * *}$ & 0.0319 & $0.0589^{* *}$ \\
\hline Economic Conditions & $(0.0184)$ & $(0.0151)$ & $(0.0252)$ & $(0.0290)$ & $(0.0252)$ & $(0.0256)$ \\
\hline Foreign Contact at & $-0.0322^{* * *}$ & $-0.0773^{* * *}$ & -0.0276 & -0.0075 & $-0.0652^{* *}$ & -0.0132 \\
\hline Work & $(0.0103)$ & $(0.0132)$ & $(0.0202)$ & $(0.0203)$ & $(0.0284)$ & $(0.0216)$ \\
\hline \multirow[t]{2}{*}{ Observations } & 6,540 & 6,495 & 2,938 & 3,041 & 3,036 & 3,037 \\
\hline & \multicolumn{6}{|c|}{ Panel C } \\
\hline Good Personal & $-0.0228^{* *}$ & $-0.0437^{* * * *}$ & $-0.0451^{* * *}$ & -0.0284 & $-0.0588^{* * *}$ & -0.0226 \\
\hline Economic Conditions & $(0.0101)$ & $(0.0121)$ & $(0.0186)$ & $(0.0203)$ & $(0.0193)$ & $(0.0177)$ \\
\hline Bad Personal & 0.0159 & $0.0304^{*}$ & $0.0597^{* * *}$ & $0.0765^{* * *}$ & 0.0339 & $0.0585^{* *}$ \\
\hline Economic Conditions & $(0.0211)$ & $(0.0177)$ & $(0.0248)$ & $(0.0290)$ & $(0.0256)$ & $(0.0260)$ \\
\hline Foreign Contact at & $-0.0339^{* * *}$ & $-0.0741^{* * *}$ & -0.0289 & -0.0026 & $-0.0645^{* *}$ & -0.0116 \\
\hline Work & $(0.0117)$ & $(0.0153)$ & $(0.0209)$ & $(0.0208)$ & $(0.0300)$ & $(0.0229)$ \\
\hline Foreign Contact in & $-0.0589^{* * * *}$ & $-0.0441^{* *}$ & $-0.0521^{* *}$ & $-0.0868^{* * *}$ & $-0.0643^{* *}$ & $-0.0530^{* * * *}$ \\
\hline Family & $(0.0117)$ & $(0.0205)$ & $(0.0221)$ & $(0.0206)$ & $(0.0247)$ & $(0.0185)$ \\
\hline \multirow[t]{2}{*}{ Nazi State in 1928} & -0.0235 & -0.0082 & $0.0614^{* * *}$ & 0.0518 & 0.0268 & $0.0532^{*}$ \\
\hline & $(0.0167)$ & $(0.0237)$ & $(0.0222)$ & $(0.0366)$ & $(0.0446)$ & $(0.0283)$ \\
\hline
\end{tabular}

Observations

5,263

2,936

3,039

3,034

3,035

Note: Standard errors clustered at the age group-state level in parentheses, ${ }^{*} p<0.1,{ }^{* * *} p<0.05$, ${ }^{* * *} p<0.01$. All regressions use sampling weights. Control variables in Panels A and B are identical to Table 3A, and also include state dummies and year dummies. Panel $\mathrm{C}$ does not include state dummies, but controls for state-level age structure of the population, state-level GDP per capita, and percent of foreigners in the state population. 
Appendix Table 6B. The Impact of Perceived Personal Economic Conditions on Attitudes towards Foreigners Regarding Marriage and Family: Females Only

(1) (2) (3) (4)

It would be unpleasant to have neighbor who is

\begin{tabular}{cccc}
\hline & Ethnic & & \\
Jewish & German & & \\
& from & Turkish Italian \\
& Eastern & & \\
& Europe & & \\
\hline
\end{tabular}

Good Personal

$\begin{array}{cccc}-0.0211^{* * *}-0.0435^{* * *} & -0.0267 & 0.0007 \\ (0.0097) & (0.0140) & (0.0184) & (0.0093)\end{array}$

Econ Conditions

$(0.0097)$

$(0.0140)$

$(0.0184)$

$(0.0093)$

$\begin{array}{llll}0.0182 & -0.0155 & 0.0239 & -0.0058\end{array}$

$\begin{array}{llll}(0.0189) & (0.0230) & (0.0309) & (0.0111)\end{array}$

Bad Personal

Econ Conditions
(5) (6)

(7)

(8)

It would be unpleasant if a ... person married into the family

\begin{tabular}{|c|c|c|c|}
\hline Jewish & $\begin{array}{c}\text { Ethnic } \\
\text { German from } \\
\text { Eastern } \\
\text { Europe }\end{array}$ & Turkish & Italian \\
\hline
\end{tabular}

Panel A

$\begin{array}{llll}3,076 & 3,137 & 3,143 & 3,148\end{array}$

$\begin{array}{ll}-0.0323^{*} & -0.0 \\ (0.0172) & (0.1\end{array}$

$-0.0444^{* *}$

$-0.0091$

$-0.0174$

0.0044

$(0.0184)$

$(0.0201)$

$(0.0165)$

Observations

3,076

Good Personal

$-0.0239^{* *}-0.0426^{* * *}-0.02950 .0004$

(0.0255)

0.0227

$-0.0073$

0.0235

3,061

3,132

$(0.0306)$

$(0.0222)$

Econ Conditions

$\begin{array}{llll}(0.0099) & (0.0142) & (0.0185) & (0.0095)\end{array}$

Panel B

Bad Personal

$\begin{array}{lllll}0.0154 & -0.0180 & 0.0227 & -0.0060\end{array}$

$\begin{array}{llll}(0.0193) & (0.0231) & (0.0316) & (0.0115)\end{array}$

$-0.0323^{*}-0.1$

3,132

3,137

3,143

Econ Conditions

$-0.0276^{*} \quad-0.0304-0.0701^{* * *}-0.0138$

$(0.0176)$

$-0.0487$

$\begin{array}{ll}-0.0143 & -0.0235\end{array}$

Foreign Contact at

$\begin{array}{lllll}(0.0152) & (0.0230) & (0.0167) & (0.0090)\end{array}$

0.0047

$(0.0175)$

(0.0206)

$(0.0167)$

Work

$\begin{array}{llll}2,992 & 3,053 & 3,058 & 3,063\end{array}$

$$
-0.0475^{* *}
$$

0.0181

$-0.0132$

0.0179

Observations

2,992

$3,053 \quad 3,058 \quad 3,063$

$(0.0235)$

(0.0249)

$(0.0318)$

(0.0236)

Good Personal

\begin{tabular}{cccccccc}
\hline$-0.0234^{* *}$ & $-0.0427^{* * *}$ & -0.0276 & 0.0006 & $-0.0308^{* *}$ & $-0.0471^{* * * *}$ & -0.0119 & -0.0227 \\
$(0.0100)$ & $(0.0146)$ & $(0.0183)$ & $(0.0097)$ & $(0.0178)$ & $(0.0169)$ & $(0.0207)$ & $(0.0167)$ \\
0.0159 & -0.0193 & 0.0263 & -0.0042 & 0.0085 & 0.0201 & -0.0101 & 0.0199 \\
$(0.0191)$ & $(0.0230)$ & $(0.0321)$ & $(0.0114)$ & $(0.0251)$ & $(0.0256)$ & $(0.0327)$ & $(0.0240)$ \\
$-0.0284^{*}$ & -0.0293 & $-0.0637^{* * *}$ & -0.0134 & $-0.0464^{* *}$ & -0.0227 & $-0.0978^{* * *}$ & -0.0131 \\
$(0.0149)$ & $(0.0233)$ & $(0.0170)$ & $(0.0092)$ & $(0.0232)$ & $(0.0227)$ & $(0.0193)$ & $(0.0135)$ \\
-0.0097 & $-0.0529^{* * * *}-0.0979^{* * * *}$ & $-0.0162^{*}$ & -0.0264 & $-0.1020^{* * *}$ & $-0.1050^{* * * *}$ & -0.0263 \\
$(0.0149)$ & $(0.0169)$ & $(0.0236)$ & $(0.0092)$ & $(0.0191)$ & $(0.0188)$ & $(0.0266)$ & $(0.0169)$ \\
0.0106 & 0.0304 & 0.0402 & 0.0061 & 0.0076 & 0.0207 & -0.0155 & 0.0253 \\
$(0.0177)$ & $(0.0264)$ & $(0.0357)$ & $(0.0118)$ & $(0.0353)$ & $(0.0319)$ & $(0.0400)$ & $(0.0259)$ \\
\hline 2,990 & 3,051 & 3,056 & 3,061 & 2,975 & 3,045 & 3,051 & 3,056 \\
\hline
\end{tabular}

Econ Conditions

Bad Personal

Econ Conditions

Foreign Contact at

Work

Foreign Contact in

Family

Nazi State in 1928

2,977

$-0.0289$

$-0.1052^{* * * *}$

$-0.0159$

$(0.0134)$ Note: Standard errors clustered at the age group-state level in parentheses, ${ }^{*} p<0.1,{ }^{* * *} p<0.05,{ }^{* * *} p<0.01$. All regressions use
sampling weights. Control variables in Panels A and B are identical to Table $3 \mathrm{~A}$, and also include state dummies and year dummies.

Panel C does not include state dummies, but controls for state-level age structure of the population, state-level GDP per capita, and percent of foreigners in the state population 


\section{Appendix Table 7A. The Impact of Perceived Personal Economic Conditions: Controlling}

for the Sentiment about Sending off Foreigners when Jobs are Scarce

\begin{tabular}{|c|c|c|c|c|c|c|}
\hline & \multicolumn{2}{|c|}{$\begin{array}{c}\text { Foreigners living in Germany } \\
\text { Should... }\end{array}$} & \multirow{2}{*}{$\begin{array}{c}(3) \\
\text { Jewish people } \\
\text { living in } \\
\text { Germany } \\
\text { should not } \\
\text { have the same } \\
\text { rights as } \\
\text { Germans }\end{array}$} & \multirow{2}{*}{$\begin{array}{c}(4) \\
\text { Ethnic } \\
\text { Germans from } \\
\text { Eastern } \\
\text { Europe living } \\
\text { in Germany } \\
\text { should not } \\
\text { have the same } \\
\text { rights as } \\
\text { Germans } \\
\end{array}$} & \multirow{2}{*}{$\begin{array}{c}\text { (5) } \\
\text { Turkish people } \\
\text { living in } \\
\text { Germany } \\
\text { should not } \\
\text { have the same } \\
\text { rights as } \\
\text { Germans }\end{array}$} & \multirow{2}{*}{$\begin{array}{c}\text { (6) } \\
\text { Italians living } \\
\text { in Germany } \\
\text { should not } \\
\text { have the same } \\
\text { rights as } \\
\text { Germans }\end{array}$} \\
\hline & $\begin{array}{c}\text {...marry } \\
\text { only people } \\
\text { of their own } \\
\text { nationality }\end{array}$ & $\begin{array}{l}\text {...not be } \\
\text { allowed to } \\
\text { take part in } \\
\text { any political } \\
\text { activity }\end{array}$ & & & & \\
\hline $\begin{array}{l}\text { Good Personal } \\
\text { Economic Conditions }\end{array}$ & $\begin{array}{l}-0.0111 \\
(0.0075)\end{array}$ & $\begin{array}{l}-0.0185^{* *} \\
(0.0089)\end{array}$ & $\begin{array}{l}-0.0368^{* * * *} \\
(0.0131)\end{array}$ & $\begin{array}{l}-0.0209^{*} \\
(0.0122)\end{array}$ & $\begin{array}{l}-0.0494^{* * * *} \\
(0.0143)\end{array}$ & $\begin{array}{l}-0.0144 \\
(0.0126)\end{array}$ \\
\hline $\begin{array}{l}\text { Bad Personal } \\
\text { Economic Conditions }\end{array}$ & $\begin{array}{c}0.0165 \\
(0.0122)\end{array}$ & $\begin{array}{l}0.0243^{* *} \\
(0.0122)\end{array}$ & $\begin{array}{l}0.0539^{* * * *} \\
(0.0194)\end{array}$ & $\begin{array}{l}0.0545^{* *} \\
(0.0237)\end{array}$ & $\begin{array}{c}0.0318 \\
(0.0204)\end{array}$ & $\begin{array}{l}0.0419^{*} \\
(0.0242)\end{array}$ \\
\hline $\begin{array}{l}\text { Kick Out Foreigners } \\
\text { when Jobs are Scarce }\end{array}$ & $\begin{array}{l}0.2345^{* * *} \\
(0.0121)\end{array}$ & $\begin{array}{l}0.3391^{* * *} \\
(0.0108)\end{array}$ & $\begin{array}{l}0.1604^{* * * *} \\
(0.0144)\end{array}$ & $\begin{array}{l}0.1775^{* * *} \\
(0.0184)\end{array}$ & $\begin{array}{l}0.2517^{* * *} \\
(0.0148)\end{array}$ & $\begin{array}{l}0.1649^{* * *} \\
(0.0135)\end{array}$ \\
\hline $\begin{array}{l}\text { Foreign Contact at } \\
\text { Work }\end{array}$ & $\begin{array}{l}-0.0142^{*} \\
(0.0076)\end{array}$ & $\begin{array}{l}-0.0263^{* * *} \\
(0.0085)\end{array}$ & $\begin{array}{l}-0.0182 \\
(0.0119)\end{array}$ & $\begin{array}{l}-0.0041 \\
(0.0146)\end{array}$ & $\begin{array}{l}-0.0291^{*} \\
(0.0151)\end{array}$ & $\begin{array}{l}-0.0086 \\
(0.0145)\end{array}$ \\
\hline $\begin{array}{l}\text { Foreign Contact in } \\
\text { Family }\end{array}$ & $\begin{array}{l}-0.0316^{* * *} \\
(0.0092)\end{array}$ & $\begin{array}{l}-0.0222 \\
(0.0150)\end{array}$ & $\begin{array}{l}-0.0366^{* *} \\
(0.0163)\end{array}$ & $\begin{array}{l}-0.0769^{* * *} \\
(0.0162)\end{array}$ & $\begin{array}{l}-0.0477^{* * *} \\
(0.0168)\end{array}$ & $\begin{array}{l}-0.0384^{* * *} \\
(0.0140)\end{array}$ \\
\hline Nazi State in 1928 & $\begin{array}{l}-0.0102 \\
(0.0106)\end{array}$ & $\begin{array}{l}-0.0024 \\
(0.0139)\end{array}$ & $\begin{array}{l}0.0604^{* * *} \\
(0.0200)\end{array}$ & $\begin{array}{c}0.0168 \\
(0.0261)\end{array}$ & $\begin{array}{c}0.0285 \\
(0.0320)\end{array}$ & $\begin{array}{l}0.0410^{*} \\
(0.0230)\end{array}$ \\
\hline Observations & 10,320 & 10,295 & 5,739 & 5,918 & 5,908 & 5,914 \\
\hline
\end{tabular}

Note: Standard errors clustered at the Agegroup-State level in parentheses, ${ }^{*} p<0.1,{ }^{* *} p<0.05,{ }^{* * * *} p<0.01$. All regressions use sampling weights, and also include the same control variables as described in Table 5a, Panel C. 


\section{Appendix Table 7B: The Impact of Perceived Personal Economic Conditions: Controlling for the Sentiment about Sending off Foreigners when Jobs are Scarce}

(1) (2) (3) (4)

It would be unpleasant to have neighbor who is

\begin{tabular}{|c|c|c|c|c|c|c|c|c|}
\hline & & \multicolumn{4}{|c|}{ into the family } \\
\hline & Jewish & $\begin{array}{c}\text { Ethnic } \\
\text { German } \\
\text { from } \\
\text { Eastern } \\
\text { Europe }\end{array}$ & Turkish & Italian & Jewish & $\begin{array}{c}\text { Ethnic } \\
\text { German } \\
\text { from } \\
\text { Eastern } \\
\text { Europe }\end{array}$ & Turkish & Italian \\
\hline Good Personal & $-0.0276^{* * * *}$ & $-0.0468^{* * * *}$ & $-0.0403^{* * *}$ & -0.0118 & -0.0109 & $-0.0360^{* * * *}$ & -0.0194 & $-0.0249^{* *}$ \\
\hline Economic Conditions & $(0.0088)$ & $(0.0137)$ & $(0.0132)$ & $(0.0074)$ & $(0.0132)$ & $(0.0121)$ & $(0.0150)$ & $(0.0100)$ \\
\hline $\begin{array}{l}\text { Bad Personal } \\
\text { Economic Conditions }\end{array}$ & $\begin{array}{c}0.0208 \\
(0.0132)\end{array}$ & $\begin{array}{l}-0.0183 \\
(0.0197)\end{array}$ & $\begin{array}{c}0.0079 \\
(0.0225)\end{array}$ & $\begin{array}{l}-0.0021 \\
(0.0110)\end{array}$ & $\begin{array}{c}0.0103 \\
(0.0188)\end{array}$ & $\begin{array}{c}0.0138 \\
(0.0192)\end{array}$ & $\begin{array}{l}-0.0227 \\
(0.0214)\end{array}$ & $\begin{array}{c}0.0219 \\
(0.0158)\end{array}$ \\
\hline $\begin{array}{l}\text { Kick out Foreigners } \\
\text { when Jobs are Scarce }\end{array}$ & $\begin{array}{l}0.1131^{* * *} \\
(0.0126)\end{array}$ & $\begin{array}{l}0.1056^{* * *} \\
(0.0123)\end{array}$ & $\begin{array}{l}0.2295^{* * *} \\
(0.0176)\end{array}$ & $\begin{array}{l}0.0630^{* * * *} \\
(0.0088)\end{array}$ & $\begin{array}{l}0.1679^{* * *} \\
(0.0176)\end{array}$ & $\begin{array}{l}0.1498^{* * *} \\
(0.0174)\end{array}$ & $\begin{array}{l}0.1847^{* * *} \\
(0.0186)\end{array}$ & $\begin{array}{l}0.1071^{* * *} \\
(0.0142)\end{array}$ \\
\hline $\begin{array}{l}\text { Foreign Contact at } \\
\text { Work }\end{array}$ & $\begin{array}{l}-0.0208^{* *} \\
(0.0097)\end{array}$ & $\begin{array}{l}-0.0216 \\
(0.0130)\end{array}$ & $\begin{array}{l}-0.0474^{* * * *} \\
(0.0145)\end{array}$ & $\begin{array}{l}-0.0171^{* *} \\
(0.0067)\end{array}$ & $\begin{array}{c}-0.0433^{\text {***** }} \\
(0.0120)\end{array}$ & $\begin{array}{l}-0.0238 \\
(0.0147)\end{array}$ & $\begin{array}{c}-0.0574^{* * *} \\
(0.0123)\end{array}$ & $\begin{array}{l}-0.0205^{*} \\
(0.0105)\end{array}$ \\
\hline $\begin{array}{l}\text { Foreign Contact in } \\
\text { Family }\end{array}$ & $\begin{array}{c}-0.0273^{* * *} \\
(0.0098)\end{array}$ & $\begin{array}{c}-0.0485^{* * *} \\
(0.0090)\end{array}$ & $\begin{array}{c}-0.0743^{* * * *} \\
(0.0164)\end{array}$ & $\begin{array}{l}-0.0122^{* *} \\
(0.0053)\end{array}$ & $\begin{array}{l}-0.0254^{*} \\
(0.0141)\end{array}$ & $\begin{array}{c}-0.1047^{* * *} \\
(0.0143)\end{array}$ & $\begin{array}{c}-0.0883^{* * *} \\
(0.0148)\end{array}$ & $\begin{array}{l}-0.0326^{* *} \\
(0.0131)\end{array}$ \\
\hline Nazi State in 1928 & $\begin{array}{l}0.0246^{*} \\
(0.0127)\end{array}$ & $\begin{array}{c}0.0033 \\
(0.0208)\end{array}$ & $\begin{array}{c}0.0073 \\
(0.0207)\end{array}$ & $\begin{array}{c}0.0027 \\
(0.0100)\end{array}$ & $\begin{array}{c}0.0236 \\
(0.0309)\end{array}$ & $\begin{array}{l}-0.0157 \\
(0.0253)\end{array}$ & $\begin{array}{l}-0.0090 \\
(0.0335)\end{array}$ & $\begin{array}{c}0.0061 \\
(0.0151)\end{array}$ \\
\hline Observations & 5,840 & 5,943 & 5,950 & 5,950 & 5,803 & 5,919 & 5,924 & 5,931 \\
\hline
\end{tabular}

Note: Standard errors clustered at the Agegroup-State level in parentheses, ${ }^{*} p<0.1,{ }^{* *} p<0.05,{ }^{* * *} p<0.01$. All regressions use sampling weights, and also include the same control variables as described in Table 5a, Panel C. 